\title{
CARACTERIZAÇÃO DE SISTEMAS DE CAFÉ ORGÂNICO SOMBREADO E A PLENO SOL NO SUL DE MINAS GERAIS
}

\author{
CÁSSIO FRANCO MOREIRA
}

Dissertação apresentada à Escola Superior de Agricultura "Luiz de Queiroz", Universidade de São Paulo, para obtenção do título de Mestre em Ecologia de Agroecossistemas.

P I R A C I C A B A

Estado de São Paulo - Brasil

Novembro 2003 


\title{
CARACTERIZAÇÃO DE SISTEMAS DE CAFÉ ORGÂNICO SOMBREADO E A PLENO SOL NO SUL DE MINAS GERAIS
}

\author{
CÁSSIO FRANCO MOREIRA \\ Engenheiro Agrônomo
}

Orientadora: Profa. Dra. ELISABETE A. DE NADAI FERNANDES

Dissertação apresentada à Escola Superior de Agricultura "Luiz de Queiroz", Universidade de São Paulo, para obtenção do título de Mestre em Ecologia de Agroecossistemas.

PIR A C I C A B A

Estado de São Paulo - Brasil

Novembro - 2003 
Dados Internacionais de Catalogação na Publicação (CIP) DIVISÃO DE BIBLIOTECA E DOCUMENTAÇÃO - ESALQ/USP

\author{
Moreira, Cássio Franco \\ Caracterização de sistemas de café orgânico sombreado e a pleno sol no sul de Minas \\ Gerais / Cássio Franco Moreira. - - Piracicaba, 2003. \\ $78 \mathrm{p}$. \\ Dissertação (mestrado) - - Escola Superior de Agricultura Luiz de Queiroz, 2003. \\ Bibliografia. \\ 1. Agricultura orgânica 2. Agricultura sustentável 3. Análise foliar 4. Análise por ativação \\ neutrônica 5. Bebidas (Qualidade) 6. Café 7. Sombreamento 8. Fertilidade do solo I. Título \\ CDD 633.73
}

\title{
"Permitida a cópia total ou parcial deste documento, desde que citada a fonte - $O$ autor"
}


Dedico,
A meusamados pais, àmerória demeusqueidos avôsea todos osqueacreditamemuma agiaultura maissustentáve 


\section{AGRADECIMENTOS}

ao meu querido avô, Carlos Fernandes Franco (in memorian), produtor pioneiro de café orgânico no Brasil e grande incentivador deste trabalho. Acima de tudo, um amante da natureza, um idealista que sempre lutou por justiça e igualdade entre os homens. Ele prontamente disponibilizou a área na Fazenda Jacarandá para a implantação do experimento e infelizmente não pôde ficar aqui conosco até o final deste trabalho vindo a falecer em 04 de julho de 2003

a Deus, por minha vida, pela natureza e por ter me propiciado a oportunidade de poder trabalhar com um tema tão apaixonante e que tanto acredito

à Juliana, pelos momentos juntos e pela paciência nesta fase final de elaboração da dissertação

a todos os meus familiares, especialmente meus pais , Gilson e Telma, minha irmã Paula, meus avôs Carlos e Súlvio (in memorian), avós Francisca e Maria e tios

à minha orientadora, Profa. Dra. Elisabete A. De Nadai Fernandes, por ter me recebido no Laboratório de Radioisótopos e me dado a oportunidade de desenvolver esta linha de pesquisa com confiança, apoio e amizade

à Fazenda Jacarandá por tudo que me proporcionou

à empresa Organic Coffee do Japão, representada pelos amigos Cláudio Ushiwata e Ryuchi Nakamura. Empresa com a qual a Fazenda Jacarandá possui uma parceria de dez anos não apenas comercial, mas de confiança, amizade e carinho pela vida, natureza e pessoas

à Universidade de São Paulo - USP 
aos profissionais envolvidos no curso de Pós - Graduação Interunidades em Ecologia de Agroecossistemas da ESALQ/CENA-USP

ao Centro de Energia Nuclear na Agricultura - CENA

ao Laboratório de Radioisótopos pela bolsa concedida através da FEALQ

à Capes pela bolsa concedida

ao Prof. Dr. Takashi Muraoka, pelas análises de fertilidade do solo e foliares

ao Prof. Dr. João Henrique Segges e ao Engenheiro Agrônomo Rogério Martins Manoel do Laboratório de Classificação e Degustação de Café do Ministério da Agricultura, Pecuária e Abastecimento (MAPA-RJ), Rio de Janeiro - RJ pelas análises de qualidade do café

ao colega de laboratório e amigo Dr. Fábio Sileno Tagliaferro pela grande ajuda na interpretação dos dados e análises estatísticas

aos amigos e colegas do Laboratório de Radioisótopos, Adriana de Angelis Fogaça, Ângela Aparecida Ferrari, Camila Elias, Cláudio Luís Gonzaga, Christian Turra, Elvis Joacir de França, Henrique Takuji Fukuma, Luís Gustavo Cofani Santos, Dr. Márcio Arruda Bacchi, Silmara Danelon e Paulo César Fávaro

aos companheiros da Fazenda Jacarandá, especialmente, José Haílton Garcia, Nelson Pereira, Rita Pereira e Rubens Teixeira Franco pelo trabalho conjunto, apoio, amizade e ajuda na coleta de amostras

aos amigos e colegas de república, Adriano, Anderson, Daniel, Marcos e Róbson

à Associação de Certificação Instituto Biodinâmico - IBD

à certificadora BCS no Brasil

à Associação de Cafeicultura Orgânica do Brasil (ACOB), representada pelos amigos Ivan Franco Caixeta e Sérgio Pedini 


\section{SUMÁRIO}

Página

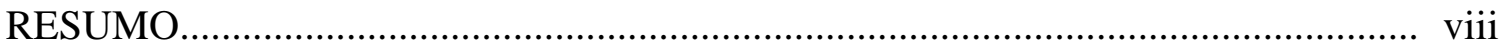

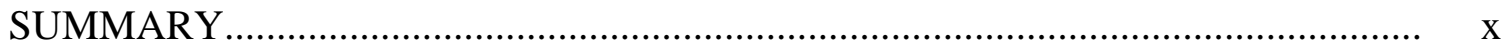

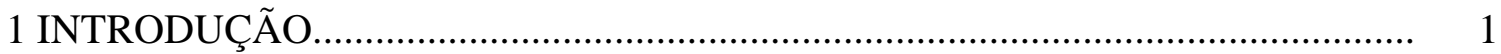

2 REVISÃO DE LITERATURA.................................................................... 4

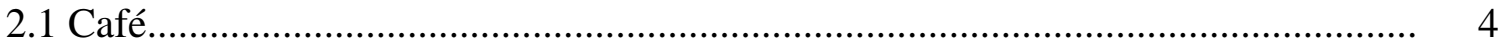

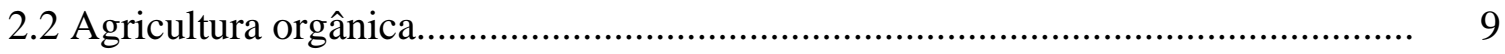

2.3 Cafeicultura orgânica............................................................................. 12

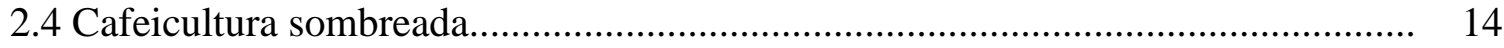

2.5 Radiação e solar e temperatura do solo................................................................ 18

2.6 Contribuição da agricultura orgânica na mitigação do efeito estufa...................... 18

2.7 Fertilidade do solo e análise foliar.................................................................. 19

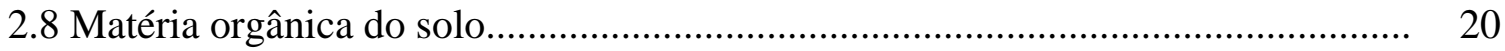

2.9 Análise por ativação neutrônica instrumental................................................... 22

2.10 Composição química elementar de grãos de café.............................................. 23

2.11 Importância dos elementos químicos no cafeeiro.......................................... 24

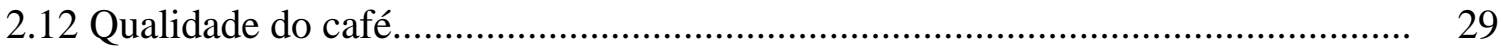

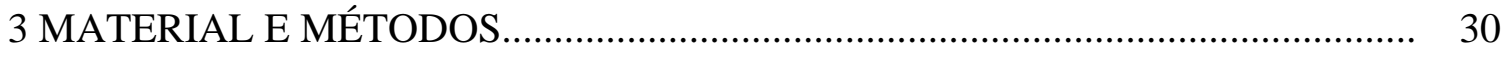

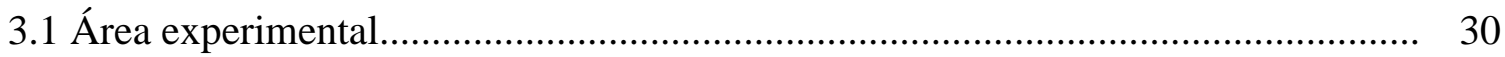

3.2 Delineamento experimental................................................................ 31

3.3 Árvore de sombreamento........................................................................ 33

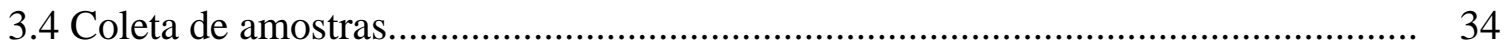

3.4.1 Coleta de solo.................................................................................... 34

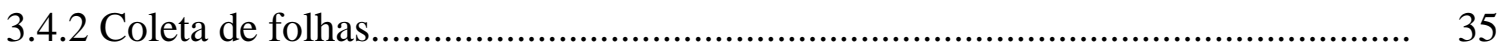


3.4.3 Coleta de grãos de café............................................................................... 35

3.5 Preparo das amostras................................................................................. 35

3.5.1 Preparo das amostras para INAA ................................................................ 35

3.5.2 Preparo das amostras de solo para fertilidade, $\mathrm{pH}$ e matéria orgânica................. 37

3.5.3 Preparo das amostras para análise foliar........................................................... 37

3.5.4 Preparo dos grãos de café para determinação da qualidade da bebida do café.... 38

3.5.5 Classificação dos grãos de café quanto àpeneira............................................... 39

3.5.6 Procedimentos práticos realizados para a determinação do tipo de café............... 40

3.5.7. Análises estatísticas.................................................................................... 42

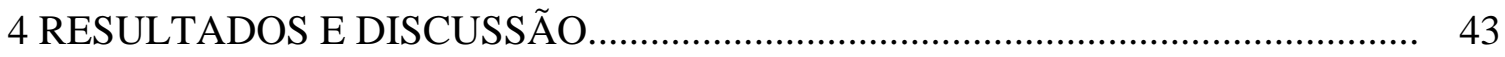

4.1 Dados de temperatura do solo e radiação solar......................................................... 43

4.2 Resultados de produção das unidades amostrais..................................................... 44

4.3 Resultados da composição química elementar de grãos, folhas e solo.................... 48

4.3.1 Resultados da composição química elementar de grãos de café........................... 48

4.3.2 Resultados da composição química elementar de folhas de café......................... 52

4.3.3 Resultados da composição química elementar de folhas da espécie arbórea Platycyamus regnellii...................................................................................... 56

4.3.4 Resultados da composição química elementar do solo....................................... 56

4.4 Resultados de fertilidade, $\mathrm{pH}$ e matéria orgânica do solo....................................... 60

4.5 Resultados de análise foliar de café ............................................................... 64

4.6 Resultados de análise foliar da espécie arbórea Platycyamus regnellii................... 68

4.7 Qualidade do café...................................................................................... 70

4.8 Considerações finais......................................................................................... 74

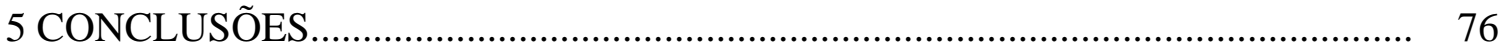

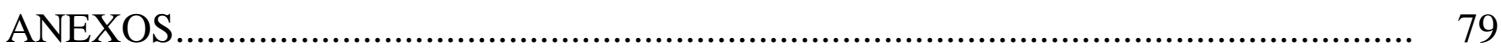

REFERÊNCIAS BIBLIOGRÁFICAS.................................................................... 93 


\title{
CARACTERIZAÇÃO DE SISTEMAS DE CAFÉ ORGÂNICO SOMBREADO E A PLENO SOL NO SUL DE MINAS GERAIS
}

\author{
Aluno: CÁSSIO FRANCO MOREIRA
}

Orientadora: Profa. Dra. ELISABETE A. DE NADAI FERNANDES

\section{RESUMO}

O consumo e o mercado de cafés especiais, como orgânicos, gourmets e socialmente justos, cresce no mundo todo oferecendo preços atraentes para o produtor, enquanto o mercado de cafés commodity encontra grande oferta e preços muito baixos. A produção orgânica revela-se como alternativa ambiental, social e econômica, pois não contamina o meio ambiente e nem as pessoas direta e indiretamente envolvidas, além de agregar mais valor ao produto final. Apesar de o Brasil ser o maior produtor mundial de café, com aproximadamente 45 milhões de sacas em 2002, a produção de café orgânico foi aproximadamente de 70 mil sacas, de acordo com a ACOB (Associação de Cafeicultura Orgânica do Brasil). O México é o maior produtor mundial de café orgânico, com aproximadamente 500 mil sacas em 2002, sendo a maioria proveniente de sistemas sombreados de café. A cafeicultura nacional caracteriza-se por extensas áreas de monocultivo a pleno sol, desconsiderando o fato do café ser uma espécie originária de florestas caducifólias da Etiópia. A produção de café orgânico brasileira também é, em sua maioria, a pleno sol, com pouca biodiversidade e grande input ao sistema. Países produtores de café orgânico em sistemas sombreados e consumidores criticam a ausência de biodiversidade do sistema brasileiro. Portanto, a pesquisa nacional deve avaliar 
cientificamente diferentes manejos de café orgânico, obtendo informações quantitativas e qualitativas, visando a sustentabilidade sócio-ambiental e ganho de competitividade internacional do produto brasileiro neste nicho de mercado. Na busca de parâmetros que permitam a caracterização do sistema sombreado e do sistema a pleno sol de café orgânico, a composição química elementar avaliada em elevado nível metrológico é uma ferramenta potencial. Esta alta confiabilidade metrológica pode ser obtida através da análise por ativação neutrônica instrumental (INAA). Para a caracterização destes sistemas de produção de café orgânico, vários elementos químicos foram quantificados por INAA em grãos e folhas de café Coffea arabica, variedade Mundo Novo, e nos solos de ambos os sistemas café sombreado por árvore leguminosa Platycyamus regnellii e café a pleno sol, na fazenda Jacarandá, Machado, Minas Gerais. Foram também avaliados os parâmetros de produtividade, fertilidade do solo, nutrição vegetal e qualidade do café. Os resultados indicam uma perspectiva positiva para a discriminação dos dois sistemas de produção utilizando-se da composição química elementar determinada por INAA. As avaliações demonstram uma tendência àsuperioridade do sistema sombreado, principalmente quanto à maiores concentrações de potássio encontrados em grãos, folhas e solo, que podem ter propiciado uma melhor qualidade do café deste sistema. 


\title{
CHARACTERIZATION OF FULL SUN- AND SHADED- ORGANIC COFFEE SYSTEMS IN THE SOUTH OF MINAS GERAIS
}

\author{
Author: CÁSSIO FRANCO MOREIRA \\ Adviser: Profa. Dra. ELISABETE A. DE NADAI FERNANDES
}

\section{SUMMARY}

The consumption of special coffee, mainly organic coffee, is increasing worldwide following the tendency of consuming products socially fair and ecologically sustainable, providing new market opportunities for coffee farmers in developing countries. The organic coffee is considered to have a better quality, once no agrochemicals are used and therefore, only the essential elements of the coffee will be present in the final product. Brazil is the largest world coffee producer, with 2,700,000 tons of green coffee in the 2002 harvest. However, only 4,200 tons are certified organic coffee, according to the Organic Coffee Brazilian Association (ACOB). The cultivation of organic coffee and shaded coffee are common in Central America, while in Brazil both conventional and organic coffee are mainly cultivated in the full sun system. Mexico, the largest world organic coffee producer, harvested 24,000 tons of certified organic coffee in the 2001-2002 season, most of it from shaded organic coffee system. In Brazil, such system is not well trusted and is also known as less productive. The full sun organic system is very criticized because of the lack of biodiversity and the high demand for external organic fertilizers. The shaded coffee system recycles more nutrients and has biodiversity, consequently, less dependent on external organic fertilizers, insecticides and fungicides. To characterize these two distinct organic 
coffee production systems, several inorganic chemical elements were quantified by instrumental neutron activation analysis (INAA) in coffee beans and leaves from Coffea arabica, variety Mundo Novo, leguminous shade tree (Platycyamus regnellii) leaves and soil from both systems at the Jacarandá farm, Machado, Minas Gerais State, Brazil. Other parameters such as productivity, soil fertility, plant nutrition and coffee quality were also evaluated. Results show a positive perspective for discrimination of the two production systems, through the chemical composition by INAA. The evaluations show a tendency of superiority for the shaded treatment, mainly according to the higher mass fractions of $\mathrm{K}$ in grains, leaves and soil, which may have caused better coffee quality. 


\section{INTRODUÇÃO}

A crescente preocupação pela manutenção da qualidade de vida e do meio ambiente tem levado a sociedade a criticar o modelo atual de produção agrícola. Com isto, torna-se necessária a adoção de métodos de produção menos agressivos ao meio ambiente, aos trabalhadores rurais e aos consumidores. É neste contexto que surge a agricultura orgânica como alternativa para produção agrícola mais sustentável, suprindo as necessidades do homem no presente e no futuro. A demanda por produtos orgânicos aumenta no mundo todo, gerando oportunidades de mercado para produtores orgânicos de diversas regiões mundiais.

A agricultura moderna implica na simplificação do ambiente em vastas áreas, substituindo a diversidade da natureza por um pequeno número de espécies cultivadas. Esta simplificação causa grande impacto e, conseqüentemente, desequilíbrio ao meio ambiente. $\mathrm{O}$ aparecimento de muitas pragas e doenças é também resultado desta simplificação. Pesquisadores, produtores e a sociedade em geral temem pela sustentabilidade a longo prazo destes sistemas de produção ecologicamente simplificados e altamente dependentes. Os cultivos agrícolas ditos convencionais ou modernos não consideram a complexidade do ecossistema natural, utilizando-se de áreas de monocultivos muito extensas e grandes quantidades de insumos nocivos, contaminando assim o ambiente e os seres vivos.

As estatísticas mundiais sobre produtos orgânicos são ainda escassas, porém dados da International Federation of Organic Agriculture Movements (IFOAM) estimam que as vendas (considerando 16 países europeus, América do Norte e Japão) de orgânicos em 2003 atinjam US\$ 25 bilhões, 19\% superior ao ano de 2001. A necessidade de informações técnicas e científicas a respeito de agricultura orgânica demanda que instituições de pesquisa desenvolvam trabalhos nesta área, visando estudar novas técnicas de produção, comprovando a sua viabilidade. 
O consumo de cafés especiais, como orgânicos, gourmets, sombreados e socialmente justos, também está aumentando. Os preços destes cafés no mercado nacional e internacional são mais atraentes para os produtores, como conseqüência de suas características de produção, qualidade e menor oferta, enquanto os cafés commodity encontram grande oferta e alto estoque mundial, resultando em preços muito baixos desde o ano 2000. Associado ao crescimento do consumo de cafés especiais está a demanda por informações de qualidade e cultivo.

Com sua origem nos altiplanos da Etiópia, Coffea arabica é uma planta que vegeta e produz bem em áreas sombreadas de altitude e em climas úmidos. É esperado, portanto, que o manejo do café que mais se aproxime de suas condições originais apresente os melhores resultados. No Brasil, as variedades de café foram geneticamente selecionadas para produção a pleno sol, entretanto o sombreamento pode oferecer vantagens, como preservação da biodiversidade, maior reciclagem de nutrientes e maturação mais uniforme dos grãos. Na maioria dos países produtores, o café ainda é cultivado em sistemas sombreados, sendo as duas grandes exceções, Brasil e Colômbia. No México, o maior produtor mundial de café orgânico, a maioria da cafeicultura é praticada em sistemas sombreados.

O Brasil, maior produtor mundial de café, respondeu por aproximadamente $40 \%$ da produção mundial em 2002. Contudo, foi apenas o $6^{\circ}$ produtor mundial de café orgânico, atrás de México, Peru, Tanzânia, Costa Rica e Equador, com 80 mil sacas de café orgânico, o que representou $0,2 \%$ de sua produção total de café. O estado de Minas Gerais é o maior produtor brasileiro e o segundo maior produtor mundial, sendo responsável por aproximadamente 50\% do café nacional, com produção superior a do Vietnã e Colômbia em 2002. O sul de Minas Gerais destaca-se como a maior região produtora de café do estado e do país, bem como, a maior região produtora de café orgânico no Brasil.

O sistema de produção de café orgânico brasileiro é criticado mundialmente, devido à ausência de biodiversidade. Pesquisadores e produtores precisam encontrar alternativas para o aumento da biodiversidade nas plantações de café nacionais, para que assim o café orgânico brasileiro ganhe mais espaço no mercado mundial.

Tem sido assumido, e até certo ponto documentado, que o sistema sombreado de café é benéfico tanto ecologicamente como economicamente. Além disto, plantações de café 
sombreado têm sido citadas como refúgios para biodiversidade, pois podem preservar um grande número de organismos. Por outro lado, também se assume que uma alta densidade de árvores irá resultar em significativa redução de produção. Entretanto, poucos são os estudos de campo para determinar esta relação entre sombreamento e produtividade. A necessidade de pesquisas nas propriedades rurais de café para estudar a relação entre as características ecológicas da sombra e as produções é amplamente reconhecida (Soto-Pinto, 2000).

Sendo assim, este trabalho visa preencher parte da lacuna de informações técnicocientíficas relacionadas com a produção de café orgânico em lavouras sombreadas. O objetivo foi caracterizar dois sistemas de cultivo de café orgânico - sombreado com a espécie arbórea Platycyamus regnellii e a pleno sol. Os parâmetros utilizados para esta caracterização incluem a determinação da composição química elementar de grãos e folhas de café e solo, através de análise por ativação neutrônica instrumental (INAA), avaliação da fertilidade do solo e análise foliar. Também foi determinada a qualidade do café, por avaliação sensorial da bebida, número de defeitos, tamanho e rendimento após o benefício dos grãos de café bem como a produtividade dos dois sistemas. 


\section{REVISÃO DE LITERATURA}

\subsection{Café}

O café (Coffea) é o principal gênero da família das Rubiáceas, que possui mais de 6000 espécies. Atualmente, duas espécies deste gênero têm importância econômica: Coffea arabica (aproximadamente $70 \%$ da produção mundial) e Coffea canephora (aproximadamente 30\% da produção mundial) (Conselho Internacional do Café, 1997; Clarke \& Macrae, 1985b; Matiello et al.,2002; Rena et al.,1986).

Acredita-se que o Coffea arabica tenha se originado nas florestas tropicais da Etiópia onde os invasores árabes verificaram que a população local tinha o hábito de mascar os frutos secos e as folhas como estimulante. Este hábito foi adotado pelos árabes que passaram então a consumir a bebida feita de frutos maduros e possivelmente também de “cerejas” torradas (Malavolta, 1974). Diversas lendas retratam seu aproveitamento pelo homem, sendo a mais famosa a do pastor etíope que observara suas cabras mais ativas após comerem folhas do determinado arbusto. Ele também passou a ingerir tais folhas, tornandose o pastor mais esperto e comunicativo da região (Graner, 1967).

No século XV, o café foi transportado da Abissínia para a Arábia, de onde foi levado para Java, cultivado em plantações e transportadas para a Holanda. Os holandeses presentearam Luís XIV, da França, com uma planta de café, replantada nos Jardins de Plantas de Paris. Destas plantas de Paris, teve origem a cafeicultura da América Central. Em 1718 vindo da Holanda, entrou na América do Sul pelo Suriname depois Guiana Holandesa e Guiana Francesa.

No Brasil, foi introduzido pelo sargento-mor Francisco de Melo Palheta no ano de 1727 trazido da Guiana Francesa para Belém do Pará. De lá seguiu ao Maranhão e se 
expandiu para os estados vizinhos em pequenas plantações atingindo a Bahia em 1770. Em 1774 foi levado para o Rio de Janeiro onde os cafezais se ampliaram. Espalhando-se para a Serra do Mar, alcançou em 1825 o Vale do Paraíba e os Estados de São Paulo e Minas Gerais.

No Sul de Minas Gerais e no estado de São Paulo, encontrou condições climáticas favoráveis para o seu cultivo, chegando a Ribeirão Preto em 1835, Campinas em 1840 e Noroeste Paulista e Norte Paranaense entre 1928 e 1930. No Espírito Santo e na região norte do Rio de Janeiro, foi introduzido a partir de 1920. O cultivo na Bahia e em Rondônia iniciou-se nos anos 70 (Graner, 1967; Malavolta, 1974, Matiello et al., 2002; Romero, 1997).

O cafeeiro da espécie arábica é uma planta tropical de altitude, adaptada a climas úmidos com temperaturas amenas. A faixa de temperatura considerada ideal vai de $16^{\circ}$ a $23^{\circ} \mathrm{C}$ e as melhores regiões são aquelas com pluviosidade acima de $1200 \mathrm{~mm} / \mathrm{ano}$. Já o café robusta (Coffea canephora) é oriundo de regiões equatoriais baixas, quentes e úmidas da bacia do Congo e está adaptado ì condições de temperatura mais elevadas, com médias anuais entre $22^{\circ} \mathrm{e} 26^{\circ} \mathrm{C}$ (Clarke \& Macrae, 1985b; Pedini, 2000).

O nome café é dado ao fruto ou ao grão do cafeeiro, além da infusão feita com o grão torrado e moído e do estabelecimento onde se vende a bebida diretamente ao público. Alguns autores admitem que a palavra café tenha se originado de Cafa, região de sua origem, na Etiópia. Muitos também concordam que tenha sido derivada da palavra árabe "qahwa" ou "kahwa", que significa vinho, e, a partir do século XIV, passou a ser usada na Arábia para designar o próprio café (Graner, 1967).

As primeiras exportações de café em quantidade ocorreram a partir de 1820 e, em 1845, o Brasil detinha 45\% da produção mundial de café. Nos anos de 1870 a 1890, o café representava quase $60 \%$ das exportações brasileiras (Matiello et al., 2002; Rufino, 2003). Difundiu-se, então, para todo o Brasil acabando por se transformar numa das maiores culturas propulsoras da economia nacional desde a época da colonização, sendo um dos principais produtos agrícolas da pauta de exportações e comércio do Brasil atualmente.

A produção de café no mundo vem aumentando, em média, 1 milhão de sacas de 60 $\mathrm{kg}$ por ano nos últimos 30 anos. Em 1970, o volume total mundial era 65-70 milhões de sacas, na década de 80 subiu para 80-90 milhões e na década de 90 atingiu 90-100 milhões 
de sacas. Desde 1999 têm ultrapassando 100 milhões de sacas e de acordo com a OIC (Organização Internacional do Café - 2002) de outubro de 2001 a setembro de 2002 foram colhidas 113 milhões de sacas de café, havendo uma tendência em manter ou mesmo aumentar a produção. Isto vem gerando um excesso de café e baixos preços (Coelho, 2002).

No período de 1970 a 1980, a produção média nacional foi 19,5 milhões de sacas/ano, com a seguinte participação por estado: Paraná (38\%), São Paulo (38\%), Minas Gerais (15\%), Espírito Santo (7\%) e outros (2\%). Já duas décadas após (1991-2000), a média foi superior, com 26,6 milhões de sacas, e a participação por estado bem distinta, ocorrendo grande aumento em Minas Gerais e redução no Paraná e São Paulo (parte devido a geadas), com a seguinte proporção: Minas Gerais (49\%), Espírito Santo (18\%), São Paulo (14\%), Paraná (7\%) e outros (12\%) (Matiello et al., 2002).

O Brasil produziu cerca de 44 milhões de sacas em 2002 (34 milhões de café arábica e 10 milhões de café robusta), respondendo por aproximadamente $35 \%$ da produção mundial, seguido pelo Vietnã com $11 \%$ e deixando a Colômbia em terceiro com 9\% (CONAB, 2002; Matiello et al., 2002; Rufino, 2003).

O estado de Minas Gerais lidera a distribuição percentual do café nacional (arábica e robusta) das colheitas das safras 2001/2002 e 2002/2003 com 48\%, seguido por Espírito Santo - 22\%, São Paulo - 11\%, Bahia - 7\%, Rondônia - 5\%, e Paraná - 4\% (Matiello et al.,2002; Rufino, 2003). Convém dizer que aproximadamente $20 \%$ da produção da Bahia, $70 \%$ da produção do Espírito Santo e 100\% da produção de Rondônia constituem-se de café robusta.

Neste ano (safra 2003), a estimativa é que sejam produzidas no Brasil cerca de 25 milhões de sacas, número próximo aos 27,6 milhões de sacas de safra de 2001 (CONAB, 2003). Esta grande produção nos anos pares e menor nos anos ímpares ocorre já há muito tempo no Brasil, demonstrando a bianualidade de produção do cafeeiro, provavelmente causada pelo "stress" sofrido pela planta na grande produção dos anos pares. Tomando-se a média de produção dos últimos 4 anos (2000-2003), a média desta década tende a ser entre 30-35 milhões de sacas (Coelho, 2002; Matiello et al., 2002; Rufino, 2003).

A área ocupada com café no Brasil nestes últimos 40 anos não variou da mesma forma que a população de cafeeiros, pois houve uma mudança no número de plantas por hectare. Espaçamentos antigos resultavam entre 800 - 1500 plantas/ha e, atualmente, este 
número está entre 3000 - 7000 plantas/ha. Em 1960, havia 4,3 bilhões de plantas de café em 4,9 milhões de hectares (= 877 plantas/ha) e em 2001 existem 5,5 bilhões de plantas de café em 2,4 milhões de hectares (= 2300 plantas/ha). A média nacional do último quadriênio (1999-2002) foi 31 milhões de sacas produzidas em 2,1 milhões de hectares de lavouras adultas, resultando em produção média de 14,7 sacas por hectare, média bem superior à 7-8 sacas/ha no período de 1960-1970 (CONAB, 2002; Matiello et al., 2002).

Desde sua descoberta, o café desempenha importante papel na economia de países produtores e de países processadores, comerciantes e consumidores, como Alemanha, Estados Unidos, Holanda e Itália. O café representa mundialmente um mercado em valores monetários só superado pelo petróleo.

O Brasil é o maior produtor mundial há mais de 150 anos e o café teve grande influência na formação do país e de importantes cidades como São Paulo, Campinas, Ribeirão Preto, Londrina, dentre outras. Atualmente o agronegócio do café envolve direta e indiretamente, cerca de 10 milhões de pessoas em uma cadeia que vai do campo àxícara (Coelho, 2002; Rufino, 2002).

Dados estimam em 8,4 milhões de empregos diretos e indiretos na cadeia do café, sendo que no período de colheita aproximadamente 3 milhões de trabalhadores sazonais aderem ao trabalho. Em 2001, havia 300.000 propriedades produtoras de café no Brasil das quais dois terços de pequeno porte (FAEMG, 2001). Além dos tradicionais produtores de café, ha também o campo de negociadores que compram o café apenas para processá-lo. Em 2001, havia 1336 o número de torrefadores no país (ABIC, 2001), 3000 de marcas próprias (FAEMG, 2001), 9 de indústrias solúveis (Coelho, 2002) e 220 de exportadores (FAEMG, 2001). As cooperativas filiadas à Organização das Cooperativas Brasileiras (OCB) em atividade somavam 49 em 2001, respondendo por 28\% do mercado de café (Coelho, 2002).

Um dos mais importantes produtos da balança comercial brasileira, o café foi responsável pela entrada de divisas da ordem de US\$2,4 bilhões em 1999, US\$ 1,76 bilhões em 2000, US\$ 1,4 bilhões em 2001 e US\$ 1,4 bilhões em 2002, ano em que ocupou o terceiro lugar entre as commodities agrícolas exportadas, atrás apenas da soja, que foi responsável pela entrada de US\$ 6,0 bilhões, e do açúcar, responsável pela entrada de US\$ 2,1 bilhões (SECEX, 2002). É interessante notar que o volume exportado vem oscilando inversamente ao valor recebido pelo produto, demonstrando a crise em que o setor se 
encontra desde 2000. Para visualizar, em 1997 foram exportadas 920 mil toneladas de café verde, gerando uma receita de US\$ 3,1 bilhões e ocupando o primeiro lugar em valor entre as commodities agrícolas exportadas, enquanto em 2002 exportaram-se 1,6 milhões de toneladas, gerando apenas US\$ 1,4 bilhões e um amargo terceiro lugar (Coelho,2002; CONAB, 2002).

Segundo o Banco Nacional de Desenvolvimento Econômico e Social (BNDES), a indústria do café está entre os dez setores da economia brasileira que geram, ao mesmo tempo, mais emprego e maior crescimento econômico (ABIC, 2001).

De acordo com o CECAFE (Conselho dos Exportadores de Café do Brasil), em 2002 foram exportadas 24,3 milhões de sacas, representando 54,5\% da safra. Destes, 21,8 milhões de sacas correspondem a café verde e apenas 2,5 milhões de sacas a café solúvel e 25.809 sacas a café torrado. Isso demonstra a pequena quantidade de café industrializado exportado pelo Brasil e o enorme potencial para aumentar essa industrialização, o que geraria mais receita para a nação.

O consumo interno brasileiro também é muito grande, sendo comercializados 790 mil toneladas, perdendo apenas para os Estados Unidos, com consumo interno de 1,1 milhão de toneladas de café em 2000 (Carvalho \& Tayra, 2001). Dados revelam que o consumo interno foi 13,6 milhões de sacas (816 mil toneladas) em 2001. O consumo per capita no Brasil que foi de 4,5 $\mathrm{kg}$ nos anos 70, caindo até 3,5 $\mathrm{kg}$ em 1985, vem subindo desde então, com 4,8 kg em 2001 (ABIC, 2001) e deve chegar a 5,0 kg per capita em 2004 (ABIC, 2001; Rufino, 2003).

Segundo a Organização Internacional do Café (OIC), no começo da década de 90, as vendas mundiais de café no varejo eram US\$ 30 milhões por ano e os países produtores ficavam com um terço (de US\$ 10 a 12 bilhões), chegando em 2001 ao extremo de US\$ 70 bilhões movimentados com café e apenas US\$ 5,5 bilhões destinados aos países produtores (OIC, 2002) .

A produção mundial tem crescido a uma média anual de $3,6 \%$, enquanto a demanda aumenta apenas 1,5\%, resultando em um estoque mundial superior a 40 milhões de sacas. De acordo com estimativa da OIC, a produção mundial em 2001/2002 foi 113 milhões de sacas e o consumo mundial 106 milhões de sacas de café (Coelho 2002, Matiello et al., 2002, Rufino, 2003 ). 
Uma das explicações para a crescente produção mundial verificada nos últimos anos consiste nos altos preços gerados pela geada de 1994 em Minas Gerais, e a conseqüente corrida ao plantio de café no Brasil, Vietnã e outros países. Estas lavouras encontram-se em fase de alta produtividade, contribuindo para o aumento do volume de café produzido no Brasil e no mundo.

\subsection{Agricultura orgânica}

A agricultura orgânica tem sido tema de debates recentes sobre os rumos da produção agrícola. Nos últimos anos, vem se apresentando como alternativa para a produção de alimentos, capaz de atender à necessidades humanas no presente e no futuro. A demanda por produtos orgânicos aumenta no mundo todo, criando novas oportunidades de mercado para produtores de café orgânico em países em desenvolvimento (Fernandes et al., 2001). É um sistema de produção agropecuário que não utiliza insumos sintéticos e persistentes no meio ambiente. Tem como princípio a reciclagem da matéria orgânica e o equilíbrio natural, incorporando animais adaptados e considerando o ser humano como parte do organismo de produção. Inspira-se na imagem de que cada ambiente e cada produto fazem parte de um complexo organismo agrícola vivo com órgãos que interagem criando um sistema harmônico e saudável (Harkaly, 2000).

O maior desafio lançado à comunidade mundial é garantir segurança alimentar, alcançando aumentos sustentáveis na produção de alimentos. A agricultura orgânica vem respondendo positivamente a tais demandas (Fernandes et al., 2001). A necessidade de informações científicas a respeito de agricultura orgânica exige, atualmente, que instituições de pesquisa desenvolvam trabalhos nesta área, visando estudar as novas técnicas de produção e comprovar a sua viabilidade.

Aproximadamente 100 países praticam a agricultura orgânica certificada e suas respectivas áreas estão crescendo progressivamente. Pesquisa da IFOAM de fevereiro de 2003 revela que a área mundial sob manejo orgânico era aproximadamente 23 milhões de hectares, sem contar as áreas certificadas de "extrativismo racional de plantas/produtos nativos" que somam mais 10,7 milhões de hectares. A Austrália é o país com maior área sob manejo orgânico (10,5 milhões de hectares), seguido da Argentina (3,2 milhões de hectares) 
cuja a maior porcentagem consiste de pastagem. A área brasileira destinada ao manejo orgânico é de 275.576 hectares.

Diferentes movimentos de agriculturas "não convencionais" são conhecidos hoje. O nome agricultura orgânica ou produto orgânico é atualmente no Brasil o mais difundido. Em outros países, são usados além do termo "organic", os termos "bio", "eco", "green" e outros, para se referenciar a produtos cultivados sob os princípios da agricultura orgânica.

Com o surgimento, em 1920, de movimentos contrários à adubação química, agrupados em quatro grandes vertentes, valorizou-se o uso da matéria orgânica e de outras práticas culturais regenerativas. Na Europa, surgem a agricultura biodinâmica, iniciada por Rudolf Steiner em 1924, a agricultura orgânica, cujos princípios foram estabelecidos entre os anos de 1925 e 1930 pelo pesquisador inglês Albert Howard, a agricultura biológica, difundida na França por Claude Aubert, e, no Japão, a agricultura natural, a partir de 1935, que se baseava nas idéias de Mokiti Okada. Estas formas de agricultura podem ser consideradas como diferentes vertentes de agricultura ecológica, alternativa ou sustentável (Ehlers, 1996; Carvalho, 2001; Theodoro, 2001). Entretanto, não se pode dizer que elas sejam exatamente iguais. A agricultura biodinâmica, por exemplo, vai muito além, considerando aspectos como relações entre o crescimento vegetal e o cosmo e o equilíbrio vital entre a produção vegetal e a produção animal.

O termo orgânico não significa apenas a realização de adubação orgânica e a não utilização de produtos proibidos, mas sim, organismo. É importante, então, que este organismo seja ecologicamente sustentável, economicamente viável e socialmente justo. (Penteado, 2000).

Muitas dúvidas persistem quanto à técnicas de produção orgânica e sua produtividade, levando muitos agricultores e criadores a adotarem práticas não autorizadas pelas certificadoras ou a utilizarem técnicas recomendadas de modo incorreto ou, ainda, não ingressarem no sistema orgânico, por acharem muito arriscado (Paschoal, 1994).

A agricultura orgânica é um sistema de produção comprometido com a saúde, a ética e a cidadania do ser humano, contribuindo para preservar a vida e a natureza. Aproveita com inteligência os recursos naturais, métodos tradicionais e as mais recentes tecnologias ecológicas. Para alcançar o seu propósito, abre mão do uso de agrotóxicos e fertilizantes químicos sintetizados artificialmente, agressivos à saúde e ao meio ambiente. Busca uma 
interação entre o agricultor e o consumidor e que atenda æ̀ necessidades de ambas as partes (Abreu, 1998).

Na agricultura orgânica, o manejo do solo apresenta diferença substancial em relação àagricultura convencional. Procura-se ter em mente que se trabalha em condições tropicais de solo e clima, incluindo manejos que mantenham a cobertura do solo o maior tempo possível, evitando sua exposição a luz solar e chuvas fortes. Realizam-se correção e adubação, visando introduzir nutrientes que estimulem uma maior atividade biológica do solo. Esta atividade biológica interfere favoravelmente na ciclagem dos elementos químicos dos complexos solo-planta, inclusive solubilizando aqueles que se encontram em forma não disponíveis aos vegetais (Serrano, 1998).

As técnicas propostas pela agricultura orgânica baseiam-se na utilização de subprodutos da reciclagem da matéria orgânica vegetal e animal em substituição àadubação química e a agrotóxicos (Grossman, 2003). Grande parte dessas técnicas está sendo aplicada ao cultivo de café, obtendo-se produções satisfatórias principalmente na região sul de Minas Gerais, interior de São Paulo e norte do Paraná (Theodoro, 2001).

Os modernos sistemas de produção vêm se tornando muito produtivos, principalmente por serem altamente dependentes de insumos externos (Conselho Internacional do Café, 1997). Um número crescente de cientistas e produtores e a sociedade em geral questionam a sustentabilidade a médio/longo prazo destes sistemas de produção de alimentos ecologicamente simplificados. Tais sistemas de produção, ditos convencionais ou modernos, não consideram a complexidade do ecossistema natural. Eles simplificam o ambiente, utilizando-se de áreas de monoculturas muito extensas e grandes quantidades de diversos tipos de insumos. Esta simplificação do sistema causa um grande impacto no ambiente e, conseqüentemente, um desequilíbrio. O aparecimento de muitas pragas e doenças é também resultado desta simplificação do ambiente. A agricultura convencional também contamina o ambiente e seres vivos através de resíduos de seus insumos (Altieri, 1999).

A certificação orgânica é um processo necessário para aqueles que desejam produzir organicamente e vender seu produto no comércio formal. É um processo de auditoria, no qual uma entidade (associação, instituto, etc) credenciada por normas nacionais e/ou internacionais, ou aceita e conhecida pela sociedade, acompanha o processo produtivo de 
uma propriedade/empresa (Conselho Internacional do Café, 1997). Este acompanhamento é realizado por meio de inspeções ì̀ unidades produtivas por técnicos capacitados da certificadora. São monitorados os insumos, as técnicas de plantio e processamento, os fluxos de volumes, vendas e rastreabilidade e também os critérios sociais e ambientais. Cada certificadora têm suas exigências, de acordo com suas filosofias e metodologias, mas os princípios básicos do não uso de agroquímicos e adubos químicos solúveis são adotados por todas (Harada, 2001).

No Brasil, existem diversas certificadoras atuando. Há pouco tempo, eram poucas e apenas nacionais, e hoje um número de aproximadamente 20 certificadoras atuam no Brasil, com grande participação de certificadoras internacionais. As certificadoras nacionais mais conhecidas são: IBD (Associação de Certificação Instituto Biodinâmico), AAOcert (Associação de Agricultura Orgânica) e MOA (Fundação Mokiti Okada). Há ainda outras, como Sapucaí, MO (Minas Orgânica), ECOVIDA, APAN (Associação de Produtores de Agricultura Natural), entre outras. Entre as certificadoras internacionais com representação e projetos certificados no Brasil, citam-se a IMO (Suíça), BCS (Alemanha), FVO (EUA), SKAL (Dinamarca), Ecocert (França) e OIA (Argentina). Entre as certificadoras nacionais, apenas o IBD é credenciado internacionalmente.

\subsection{Cafeicultura orgânica}

O consumo de cafés especiais, como os orgânicos, tem aumentado à medida que a sociedade vem questionando a sustentabilidade do modelo agrícola atual. Utilizando-se de grandes quantidades de insumos, a agricultura brasileira é responsável por uma série de intoxicações a seres humanos (direta e indiretamente), animais e ao meio ambiente (Coelho, 2002).

A cultura do café é a terceira no país a receber maiores quantidades de agrotóxicos, com um total geral de 30 mil toneladas de produtos vendidos em 2000, perdendo apenas para o milho e a soja. Quanto ao valor gasto com agrotóxicos no país, o café se encontrava em quarto lugar em 2000, com US\$ 161 milhões, perdendo para soja, milho e algodão, primeiro, segundo e terceiro colocados, respectivamente (SINDAG, 2003). Vale dizer que o café ainda é uma cultura que utiliza muita mão de obra, expondo os trabalhadores a estes 
agrotóxicos, enquanto que a soja, o milho e o algodão são culturas mais mecanizadas e menos dependentes de mão-de-obra.

A Fazenda Jacarandá, localizada no município de Machado, sul de Minas Gerais, com uma área total de 230 ha, dentre os quais cerca de 100 cultivados com café orgânico, foi uma das pioneiras na exportação de café orgânico do Brasil. Desde 1993, a Fazenda Jacarandá fornece café orgânico à empresa "Organic Coffee" de Fukuoka, no Japão (Theodoro, 2001).

O café do tipo commodity é caracterizado e valorizado, considerando somente o produto final, através da avaliação de números de defeitos nos grãos, tamanho dos grãos e qualidade da bebida. Já os cafés diferenciados, especiais e com certificados de origem buscam mercados mais exigentes, onde o consumidor quer um produto que seja realmente de qualidade. Esta qualidade não necessariamente está na bebida ou nos defeitos dos grãos, mas sim no sistema de produção. Assim sendo, surgiram cafés com certificados orgânicos, que respeitam direta ou indiretamente os indivíduos e o meio ambiente, cafés com certificados sociais ("Fair trade”), respeitando os aspectos sociais, cafés amigos dos pássaros ("Bird friendly"), cafés amigos da biodiversidade ("Biodiversity friendly"), cafés sombreados ("Shaded coffee") e outros tipos de cafés e produtos certificados (Gobbi, 2000; Saes, 2001).

Em seu habitat original o café pertence a uma estrutura florestal associado a diversas espécies silvestres, embora atualmente seja cultivado em ambientes abertos como monocultura (Santana \& Fará, 2000).

É muito comum o uso de árvores na maioria dos países produtores de café, sendo as duas grandes exceções Brasil e Colômbia. A utilização de árvores nas lavouras de café é benéfica quanto à promoção de maior biodiversidade e equilíbrio do ambiente. Oferece também uma série de outras vantagens, como maior reciclagem de nutrientes, minimizandose o uso de insumos externos.

O Brasil, maior produtor de café convencional, respondeu por aproximadamente $40 \%$ da produção mundial em 2002. Contudo, foi apenas o $6^{\circ}$ produtor mundial de café orgânico, atrás de países como México, Peru,Tanzânia, Costa Rica e Equador, com 80 mil sacas de café orgânico, representando $0,2 \%$ de sua produção total de café (ACOB, 2002). 
O México, com aproximadamente 45.000 ha certificados em 1998 (Grossman, 2003), produziu 400 mil sacas de café orgânico (grande parte sombreado) das aproximadamente 900 mil sacas produzidas no mundo em 2002 (ACOB, 2002).

O Brasil precisa investir esforços para elevar sua produção de café orgânico, aliando qualidade e sustentabilidade sócio-ambiental, garantindo assim competitividade nas exportações (Moreira et al., 2002).

\subsection{Cafeicultura sombreada}

O sombreamento feito com espécies e espaçamentos adequados pode trazer resultados satisfatórios quando comparado ao cultivo a pleno sol. Segundo Fernandes (1986), os principais efeitos esperados pela arborização são: produção de internódios mais longos; redução do número de folhas, porém folhas com maior tamanho; produção de frutos maiores, mais moles e açucarados; melhoria do aspecto vegetativo do cafeeiro; aumento do número de ramos primários e secundários; aumento da capacidade produtiva do cafeeiro; obtenção de cafés com bebida mais suave; redução da bianualidade de produção e menor incidência da seca de ponteiros e da cercosporiose.

Matiello (1995) cita como vantagens do sistema de arborização: (a) diminuição da desfolha mantendo os cafeeiros mais verdes e com baixo ataque de bicho mineiro; (b) safras ligeiramente menores, porém sem os extremos de altas e baixas produtividades; (c) maturação dos frutos mais lenta com possibilidade de maior porcentagem de frutos a serem descascados e despolpados; (d) atenuação das temperaturas máximas do ambiente, favorecendo o plantio do café arábica em condições de temperaturas superiores æ̀̀ ideais $\left(19^{\circ} \mathrm{C}-21^{\circ} \mathrm{C}\right)$; (e) aumento das temperaturas mínimas do ambiente, possibilitando uma boa proteção contra geadas; (f) proporciona renda adicional ao agricultor e (g) redução da infestação de mato na lavoura. Outros aspectos positivos do sistema sombreado segundo Rodrigues et al. (2001) são: a ciclagem de nutrientes; a diminuição da taxa de decomposição da matéria orgânica do solo, resultado da redução da temperatura do solo; a presença de controladores naturais de pragas e doenças e a possibilidade de melhorar a utilização da mão-de-obra na entressafra. 
A esse aspecto deve ser acrescentado que se a espécie utilizada na arborização tiver valor econômico, ela poderá auxiliar no custeio da lavoura cafeeira, o que tem expressiva importância nos períodos em que a oferta de café é muito grande, com conseqüente queda no preço obtido por saca (Alvarenga, 1998).

A arborização é também recomendada como atenuante da ação dos ventos, no sentido de controlar seus efeitos mecânicos diretos ou indiretos, pelas reações fisiológicas prejudiciais ou pelos ferimentos provocados, que facilitam a penetração de microrganismos (Camargo, 1985).

O papel das árvores na conservação de solos e cursos de água é bem estabelecido. Além disso, plantações de café sombreado têm sido citadas como refúgios para biodiversidade porque podem preservar a alta diversidade de organismos, como pássaros, artrópodos, mamíferos e orquídeas (Gobbi, 2000). Mais recentemente, o uso de árvores no sequestro de carbono tem sido proposto como um meio para aumentar a renda de pequenos produtores de café no México. Também, a função de árvores como uma fonte de renda através de seu potencial de produzir madeira e frutas tem sido bem documentada (Soto-Pinto et al., 2000).

Evidências sugerem que plantações de café sombreado ajudam preservar a biodiversidade e portanto merecem proteção (Gobbi, 2000).

A idade da lavoura de café e seu porte podem influenciar produções. Entretanto, poucos estudos têm sido realizados descrevendo os efeitos de fatores ambientais, especialmente fatores limitantes (fertilidade do solo, disponibilidade de água, temperatura) e suas interações com as produções de café (Beer et al., 1998). A maioria dos estudos de café tem sido desenvolvidos em campos experimentais. Estudos nas lavouras dos produtores são escassos e somente qualitativos (Muschler and Bonnemann, 1997).

Na maioria dos países, o café é produzido em sistemas sombreados, com as exceções de Colômbia, Brasil e regiões da Costa Rica. Os cafés produzidos na Etiópia, Sumatra, Nova Guiné e Timor são praticamente todos cultivados sob sombra. Na América Latina, os cafés do sul do México, norte da Nicarágua, El Salvador, Peru, Panamá e Guatemala são todos cultivados sob sombra. Além disto, a maioria do café orgânico certificado produzido mundialmente é cultivado sombreado, enquanto no Brasil é a pleno sol. 
A cafeicultura nacional é caracterizada por áreas extensas de monocultura a pleno sol, não considerando o fato do café ser uma espécie originária de florestas caducifólias da Etiópia (Ricci et al., 2002).

O sistema de produção de café orgânico no Brasil é criticado devido àescassez de biodiversidade nas lavouras. As plantações orgânicas nacionais são mundialmente vistas como "non-friendly", monoculturas, sem árvores e com grande uso de matéria orgânica externa àpropriedade (Moreira et al., 2002).

Em sistemas de produção de café orgânico, uma preocupação técnicoambiental, é a implantação da lavoura desrespeitando-se o princípio da biodiversidade. Principalmente em áreas de culturas perenes, é exigido a introdução de outras espécies, de preferência árvores nativas, para evitar a monocultura (Theodoro, 2001).

A necessidade de pesquisas nas propriedades rurais de café para estudar a relação entre as características ecológicas da sombra e as produções é amplamente reconhecida (Soto-Pinto et al., 2000). Resultados de pesquisas na América Central mostram que a porcentagem de cobertura da lavoura por árvores de sombra tiveram efeitos significativos nas produções de café. Cobertura da lavoura entre 23 e $38 \%$ por árvores de sombra aumentaram a produção de café e mantiveram até $48 \%$ de cobertura. Contudo, a produção pode diminuir a partir de $50 \%$ de cobertura da lavoura (Soto-Pinto et al., 2000).

Por outro lado, tem sido assumido que uma alta densidade de árvores vai resultar em colheitas significativamente menores para produtores de café. Entretanto poucos estudos em propriedades foram conduzidos para determinar a relação entre sombra e produção de café. A necessidade de investigar esta relação tem sido reconhecida como uma prioridade por especialistas em sistemas agroflorestais com café (Muschler \& Bonnemann, 1997; Beer, 1998). Contudo, há de se considerar separadamente a cafeicultura na região dos trópicos (América Central e norte da América do Sul) e a cafeicultura do centro-sul do Brasil. Nas regiões de latitudes mais baixas, o clima é mais uniforme durante o ano, com alta umidade, fotoperíodo constante e temperatura alta. Este fato leva a planta de café a um comportamento muito diferente do que nas médias latitudes, onde a temperatura, umidade e fotoperíodo variam ao longo do ano, com inverno seco, frio e de dias curtos.

O café é uma espécie tropical de floração gregária onde todas as plantas individuais, numa certa extensão geográfica florescem simultaneamente (Camargo, 2001). Todavia, 
ocorre o lançamento de um número variável de floradas, desde poucas nas regiões cafeeiras das latitudes médias, com época de seca definida, até várias ao longo do ano nas regiões equatoriais chuvosas. Assim, enquanto na região cafeeira do Sul do Brasil aparecem 2-3 floradas de intensidades decrescentes, na Costa Rica verificam-se até 12-15. Este hábito reprodutivo observado nas regiões equatoriais conduz a uma série de dificuldades práticas, relacionadas com colheitas parciais prolongadas, controle efetivo de doenças ou pragas, e qualidade dos grãos.

Os cafeeiros em sistemas sombreados necessitam de menos adubo, principalmente nitrogenado, para uma mesma quantidade de café produzido. Dados obtidos na Costa Rica demonstram esse fenômeno, explicado pela maior atividade da nitrato-redutase sob menor luminosidade (cafeeiro planta C3 = máximo de fotossíntese sob luz difusa). Além disto, o processo produtivo desde a floração até a maturação é mais lento e, assim, melhor atendido pela produção de reservas sob condição de sombra (Matiello et al., 2002).

Diversos sistemas de plantio de café são reconhecidos, dependendo do tipo de dossel e da densidade de árvores de sombra, tais como monocultura a pleno sol; sistemas com árvores de uma espécie; sistemas com diferentes espécies introduzidas; sistemas sob sombra densa natural (Gobbi, 2001; Soto-Pinto, 2000).

Sistemas de café sombreados, especialmente com sombra natural densa, são responsáveis por manter auto nível de biodiversidade (Perfecto et al., 1996).

A alta incidência de broca do cafeeiro (Bergamin, 1946) e ferrugem do cafeeiro (Agrios, 1982) parece ocorrer em plantios de café sombreados. Em vista disto, as práticas promovem uma redução da sombra, aumentando a confiança em novas e super produtivas variedades, uso de insumos químicos, podas e altas densidades de café (Coyner, 1960; Perfecto et al., 1996). Naturalmente, isto reduz a paisagem e a diversidade de espécies. No Brasil, as variedades de café foram geneticamente selecionadas para produção a pleno sol, mas o sombreamento pode oferecer vantagens, como aumento da biodiversidade, maior reciclagem de nutrientes e maturação mais uniforme dos grãos (Moreira et al., 2003).

A falta de pesquisas em sistemas agroflorestais no Brasil é um problema para o desenvolvimento da cafeicultura sombreada no país. As pesquisas privadas e públicas têm como foco principal a produtividade, deixando a qualidade e a sustentabilidade da produção como objetivos secundários (Saes et al., 2001). 


\subsection{Radiação solar e temperatura do solo}

A irradiância de saturação para o café está compreendida em torno de $300 \mu \mathrm{mol} \mathrm{m}{ }^{-2}$

$\mathrm{s}^{-1}$ a $600 \mu \mathrm{mol} \mathrm{m} \mathrm{s}^{-1}$, permitindo que se faça um adequado manejo das lavouras em termos de sombreamento, com base nesses dados (Kumar \& Tiesen, 1980; Fahl et al., 1994).

Altas intensidades luminosas saturam intensamente o aparelho fotossintético do cafeeiro, acarretando fotoinibição (Nunes et al.,1993).

A temperatura do solo também é muito importante para um bom desenvolvimento do cafeeiro, sendo que a ideal para o Coffea arabica situa-se entre $24^{\circ} \mathrm{C}$ e $27^{\circ} \mathrm{C}$. Temperaturas de solo superiores, principalmente acima dos $33^{\circ} \mathrm{C}$, acarretarão prejuízo ao cafeeiro (Matiello et al., 2002) como, por exemplo, flores anormais (Rena \& Maestri, 1986).

\subsection{Contribuição da agricultura orgânica na mitigação do efeito estufa}

A produção de animais e o uso de fertilizantes sintéticos são responsáveis por aproximadamente metade da emissão de $\mathrm{NH}_{3}$. Estima-se que países em desenvolvimento liberam $66 \%$ da emissão anual de $\mathrm{NH}_{3}$ oriundos de excretas animais e $80 \%$ oriundos do uso de fertilizantes. Além de serem comumente utilizados em excesso, os fertilizantes nitrogenados são muito solúveis e facilmente perdidos por lixiviação, erosão e evapotranspiração, contaminando águas e atmosfera, uma das razões pela qual não é permitido seu uso na agricultura orgânica. De acordo com o cenário, a emissão total de $\mathrm{NH}_{3}$, associada àprodução de alimentos em países em desenvolvimento, vai aumentar de 22 para 30 milhões de toneladas por ano entre 1990 e 2025 (Bouwan, 1997).

Foram monitorados os fluxos de $\mathrm{N}_{2} \mathrm{O}$ em pastagens fertilizadas com $\mathrm{N}$, sem fertilizar, com pastejo e sem pastejo em diferentes tipos de solo na Holanda. A aplicação de fertilizantes nitrogenados e o pastejo aumentou o fluxo de $\mathrm{N}_{2} \mathrm{O}$ em todos os tipos de solos (Swart, 1994).

A agricultura orgânica, seguindo seus princípios de biodiversidade, geração de biomassa vegetal, acúmulo de matéria orgânica e conservação do solo, consegue fixar $\mathrm{C}$ e $\mathrm{N}$ atmosférico no sistema e reduzir as adubações nitrogenadas, através de técnicas como 
plantios de adubos verdes, árvores e manejo do mato nativo, mitigando as mudanças globais causadas pelo efeito estufa.

\subsection{Fertilidade do solo e análise foliar}

É importante conhecer o estado nutricional do cafeeiro conduzido em diferentes sistemas de produção orgânica para detectar possíveis desequilíbrios nutricionais e identificar quais os nutrientes mais limitantes. Esta identificação é comumente realizada por meio de determinação de fertilidade do solo complementada por análise foliar (Grossman, 2003; Theodoro, 2002).

O campo da fertilidade e nutrição em agricultura orgânica carece de maior investigação, àluz dos conceitos de Chaboussou e da teoria da trofobiose, que interrelaciona a nutrição e a sanidade vegetal (Costa \& Campanhola, 1997). Neste aspecto, são feitas restrições aos adubos minerais convencionais, por seu potencial efeito negativo sobre alguns microrganismos do solo e possível incremento de problemas fitossanitários, principalmente no caso do nitrogênio (Chaboussou, 1995).

Em ambientes naturais, sem limitações hídricas, os solos férteis sustentam ecossistemas com florestas complexas em flora e fauna. Quando usados para a agricultura, proporcionam fartas colheitas sem uso de adubos, enquanto persistir sua fertilidade natural (Raij, 1991).

Um objetivo principal da produção orgânica é manter a fertilidade natural do solo. A fertilidade do solo pode ser definida como sua habilidade em produzir uma cultura satisfatoriamente com o mínimo uso de recursos como fertilizantes químicos e estercos (Doran et al., 1994).

A redução da biodiversidade do meio ambiente é negativa porque a reciclagem de nutrientes e o balanço correto entre a matéria orgânica, organismos do solo e diversidade de plantas são componentes necessários de um ambiente de solo produtivo e ecologicamente balanceado (Hendrix et al., 1990).

A importância do equilíbrio nutricional, durante todo o ciclo do cafeeiro, é fundamental para a obtenção de alta produtividade e, para isso, cada nutriente deve estar disponível na solução do solo em quantidades e proporções adequadas. A existência do 
nutriente no solo, mesmo que supostamente em quantidades disponíveis, não garante seu suprimento à plantas, em razão da influência dos vários fatores no processo de absorção (Costa, 1997).

Acredita-se que as práticas orgânicas de nutrição do solo e das plantas poderão contribuir para alterações substanciais dos atuais conceitos da adubação mineral convencional (Costa \& Campanhola, 1997). A capacidade do solo em sustentar a produtividade biológica, as vezes referida como qualidade do solo, pode ser estimada pela avaliação de parâmetros físicos, químicos e biológicos (Karlen et al., 1997).

O termo "saúde do solo", usado como um sinônimo de qualidade do solo, é empregado por aqueles que consideram o solo como um sistema vivo e dinâmico, cujas funções são mediadas por uma gama de organismos que requerem práticas próprias de manejo e conservação. Mundialmente, práticas de manejo inadequadas têm levado muitos solos à degradação e à perda de qualidade. Portanto, a qualidade do solo, estabelecida por suas propriedades físicas, químicas e biológicas dentro das restrições impostas pelo clima e o ecossistema, inclui também um componente determinado pelas decisões de uso da terra (tipo de exploração) e práticas de manejo (modo de exploração) (Doran, 2000).

\subsection{Matéria orgânica do solo}

Os resíduos de cultivos são importantes componentes na estabilidade do ecossistema da terra agricultável do mundo. Estes resíduos podem ter significativo efeito na matéria orgânica do solo, níveis de biomassa microbiana, taxas de decomposição e dinâmicas de nutrientes (Blaine, 1992).

O uso e o manejo de resíduos de cultivo, matos nativos, adubos verdes e árvores protegem o solo da erosão causada pelo vento e pela água, mantêm a produtividade e a matéria orgânica do solo, melhorando as propriedades físicas, químicas e biológicas do solo.

A quantidade de matéria orgânica tem um papel central na manutenção da fertilidade do solo (Christensen and Johnston, 1997), como importante regulador de numerosas restrições ambientais à produtividade das culturas. A mineralização de resíduos em decomposição é uma grande fonte de nutrientes à plantas (Sanchez et al., 1989). 
A matéria orgânica do solo exerce um papel essencial no desenvolvimento e funcionamento do ecossistema terrestre. Em ambos, solos não trabalhados e solos cultivados, a produtividade potencial é diretamente relacionada com a concentração de matéria orgânica (Blaine, 1992). Esta é resultante principalmente da decomposição de resíduos de origem animal e vegetal. Esses resíduos, ao serem depositados, sofrem inicialmente decomposição parcial pela mesofauna e, posteriormente, ação decompositora dos microrganismos, sendo fonte fundamental de nutrientes como o N, P , K, Ca, S e outros (Camargo et al., 1999; Jordan, 1995; Pritchett \& Fisher, 1985). Sua constituição química não pode ser especificamente definida, considerando a diversidade de resíduos orgânicos e as reações envolvidas no processo de formação da matéria orgânica do solo (Raij, 1991).

A principal característica física do solo afetada pela matéria orgânica é a agregação. A partir do seu efeito sobre a agregação, indiretamente são afetadas as demais características físicas do solo, como a densidade, a porosidade, a aeração, a capacidade de retenção e a infiltração de água, entre outras, que são fundamentais à capacidade produtiva do solo (Camargo et al., 1999).

Pesquisas "on farm" têm mostrado que boas práticas de manejo provocam uma sensível resposta na matéria orgânica do solo e nas diversas propriedades físicas, químicas e biológicas do solo a ela associadas (Wander \& Drinkwater, 2000).

Reddy \& Singh (1993), estudando um processo de sucessão florestal nos Himalaias, observaram uma recuperação das propriedades do solo com um aumento do valor de $\mathrm{C}$ e de nutrientes (N, P, Ca e K ), em função do estágio da regeneração florestal.

Avaliando os acúmulos de matéria orgânica e nutrientes em solos submetidos a pousios com acácia no Senegal, Deans et al., (1999) constataram uma significativa correlação entre as quantidades de matéria orgânica do solo e as quantidades de nutrientes (N, P e K) na camada superficial do solo.

Chambers et al., (1999), estudando a geologia de bacias de drenagem em Nevada, EUA, evidenciaram a importância da matéria orgânica ao encontrar significativa correlação entre a matéria orgânica do solo e o nitrogênio total, capacidade de troca de cátions e potássio extraível. 
A degradação do sistema do solo através de perda de matéria orgânica é resultado da movimentação excessiva do solo (Follet \& Schimel, 1989) e da retirada da vegetação natural (Srivastava \& Singh, 1989).

Superar o declínio de matéria orgânica no solo é um componente importante no desenvolvimento de agroecossistemas mais sustentáveis, bem como reduzir a destruição de ambientes naturais, característica da agricultura itinerante (Sanchez, 1990).

\subsection{Análise por ativação neutrônica instrumental}

A análise por ativação neutrônica instrumental (INAA) constitui técnica de alta qualidade metrológica com exatidão adequada a análises ambientais, favorecendo a comparabilidade de resultados (Bode et al., 2000; Bacchi et al., 2000). Baseia-se no bombardeamento de amostras com nêutrons, que interagem com os nuclídeos que as compõem, formando radionuclídeos pela reação conhecida como ativação.

Essas reações ocorrem nos núcleos atômicos de diversos elementos, normalmente pela captura de um nêutron, quando a amostra é bombardeada. Se o nuclídeo produto for radioativo, então as propriedades e intensidades da radiação característica emitida a partir de seu decaimento podem ser utilizadas para a determinação do elemento, sendo este o princípio básico da análise por ativação neutrônica.

A energia da radiação emitida é característica para cada nuclídeo permitindo sua identificação, e sua intensidade depende do número de nuclídeos ativados. O número de nuclídeos ativados é proporcional ao número de átomos presentes na amostra, dependendo, também, do fluxo de nêutrons incidente, da seção de choque e da abundância isotópica do nuclídeo alvo, calculando-se a concentração do elemento na amostra a partir destas informações (Hoste et. al, 1971; De Soete et al., 1972; Alfassi, 1990).

A análise por ativação neutrônica é uma das mais sensíveis e precisas da análise elementar quantitativa, que, por ser instrumental, não depende de separações ou dissoluções de amostras, além de permitir determinação multielementar. Recentemente, esta técnica foi avaliada sob o ponto de vista da metrologia, concluindo-se ser adequada para validação de testes de proficiência, desenvolvimento de materiais de referência e métodos de referência. Além disso, em certas condições de trabalho, a INAA pode concordar com as definições de 
método primário ou definitivo exigidas pela CCQM (Bode et al., 2000; Greenberg et al., 2000).

Entre as modalidade de análise por ativação neutrônica, a mais utilizada é a análise por ativação neutrônica instrumental. Esta minimiza o trabalho de preparo das amostras, estando geralmente restrito àobtenção de um material seco, fino e homogêneo.Não necessita de separações químicas e dissolução de amostras, o que proporciona um procedimento analítico mais fácil, reduz a possibilidade de contaminação e evita a ocorrência de fracionamentos ou recuperações parciais de elementos (Tagliaferro, 2003). Além disso, prescinde de tratamento químico de amostras e possui aplicabilidade comprovada em estudos que envolvem matrizes biológicas complexas (Oliveira et al., 1997; Saiki et al., 1997; Naidu et al.,1999).

\subsection{Composição química elementar de grãos de café}

A composição química do café depende da espécie e da variedade em questão e também de outros fatores como práticas agrícolas, grau de maturação e condições de armazenamento. O conteúdo mineral de grãos de café verde é aproximadamente $4 \%$ da matéria seca, com o potássio representando cerca de $40 \%$ deste valor. O cálcio e o magnésio estão presentes em quantidades inferiores, similares a do fósforo e do enxofre (Clarke \& Macrae, 1985a).

O café em grão apresenta concentrações de 8,6 \% a 12,6 \% de proteínas, 12,3\% a 14,0\% de lípideos e 3,5\% a 4,5\% de minerais, dependendo da variedade considerada. Alguns minerais essenciais para o funcionamento metabólico normal de um organismo podem ser encontrados no café cru. Dentre esses, destacam-se os elementos $\mathrm{Ca}, \mathrm{K}, \mathrm{Mg}, \mathrm{Na}$, $\mathrm{P}$, presentes em maiores quantidades e os elementos $\mathrm{Co}, \mathrm{Cr}, \mathrm{Cu}, \mathrm{Fe} \mathrm{Mn}, \mathrm{Zn}$, em menores quantidades. O café em grão ainda apresenta $\mathrm{Ni}$, um elemento provavelmente essencial, além de $\mathrm{Al}$, Ba e outros elementos. As concentrações dos elementos em mg $\mathrm{kg}^{-1}$, empregando-se a técnica de espectrometria de emissão ótica em plasma indutivamente acoplado (ICP-OES) foram: Al (0.612 a 32.2), Ba (1.11 a 17.6), Ca (925 a 1889), Co (0 a 1.16), $\mathrm{Cu}$ (6.21 a 369), Fe (23.3 a 367), K (12252 a 17205), Mg (1526 a 2059), Mn (14.2 a 60.4), Ni (0 a 44.2), P (1172 a 1826) e Zn (3.71 a 57.0) (Morgano, 2002). 
Tagliaferro (2002), analisando grãos de café orgânico e convencional oriundos do sul de Minas Gerais, através de análise por ativação neutrônica instrumental, encontrou as seguintes concentrações médias: $\mathrm{Al}$ (29 a 300), $\mathrm{Ba}(2,2$ a 3,5), $\mathrm{Br}(0,224$ a 0,54), $\mathrm{Ca}(1070$ a 1480), Cl (156 a 260), Co (0,0290 a 0,37), Cs (0,0290 a 0,101), Cu (17,4 a 19,3), Fe (25,5 a 300), K (17200 a 19600), Mg (2030 a 2330), Mn (14,8 a 23,8), Na (2,72 a 4,6), Rb (22,3 a 40,3), S (1400 a 2000), Sc (0,00048 a 0,06) e Zn (5,31 a 6,1).

Trabalhos de Martin et al. (1998a, 1999) mostraram ser possível caracterizar diferentes espécies de café (Arábica e Robusta) pela composição química elementar, bem como pelo seu conteúdo de cafeína e aminoácidos livres (1998b). Krivan et al. (1993) conseguiram determinar a região de origem do café baseando-se na sua composição química elementar. Wieser et al. (2001) encontraram variações entre as razões isotópicas de ${ }^{11} \mathrm{~B}$ e ${ }^{12} \mathrm{~B}$ em grãos de café, produzidos em diversas regiões geográficas, sendo estas diferenças atribuídas àcomposição isotópica das fontes de B, como solo, fertilizantes e água. Também foram comparadas duas amostras de café mexicano, uma convencional e outra orgânica. As concentrações de $\mathrm{B}$ nas duas amostras foram iguais, entretanto as razões isotópicas de ${ }^{11} \mathrm{~B}$ e

${ }^{12}$ B foram significativamente diferentes. Costa Freitas \& Mosca (1999) caracterizaram com sucesso a origem geográfica de cafés torrados pela determinação de compostos voláteis (fração aromática). Por meio da composição química elementar de grãos de café, determinada por INAA, e técnicas estatísticas KDD / Data Mining, Fernandes et al. (2002) conseguiram distinguir cafés cultivados sob diferentes sistemas de produção (orgânico e convencional) de um mesmo município em Minas Gerais.

\subsection{Importância dos elementos químicos no cafeeiro}

As plantas sintetizam carboidratos a partir de água, dióxido de carbono e energia solar pelo processo da fotossíntese, sendo portanto organismos autotróficos (Martinez et al.,1999). Entretanto, outros elementos são necessários para obter carboidratos complexos, aminoácidos e proteínas, constituindo assim o tecido da planta e exercendo funções essenciais (Gliessman, 2001). 
Os elementos químicos que são vitais à vida vegetal são, portanto, considerados nutrientes. Os elementos encontrados na natureza com esta função são: $\mathrm{C}, \mathrm{H}, \mathrm{O}, \mathrm{N}, \mathrm{P}, \mathrm{S}, \mathrm{K}$, $\mathrm{Ca}, \mathrm{Mg}, \mathrm{Mn}, \mathrm{Fe}, \mathrm{Zn}, \mathrm{B}, \mathrm{Cu}, \mathrm{Mo}$ e $\mathrm{Cl}$.

Muitas são as propriedades destes elementos nos organismos vivos. Nas plantas em geral, eles ocorrem em quantidades distintas de acordo com a necessidade, classificando-se em macronutrientes e micronutrientes, sendo igualmente importantes, embora exigidos em diferentes proporções (Malavolta, 1987; Raij, 1991).

Os macronutrientes $\mathrm{C}, \mathrm{H}, \mathrm{O}, \mathrm{N}, \mathrm{P}, \mathrm{S}, \mathrm{K}, \mathrm{Ca}$ e $\mathrm{Mg}$ são exigidos em quantidades maiores pelos cafeeiros, geralmente em quilogramas por hectare. Os micronutrientes $\mathrm{Mn}$, $\mathrm{Fe}, \mathrm{Zn}, \mathrm{B}, \mathrm{Cu}, \mathrm{Mo}$ e $\mathrm{Cl}$ são requeridos em quantidades menores, geralmente em gramas por hectare.

O carbono $(\mathrm{C})$ tem origem do ar, o oxigênio $(\mathrm{O})$ do ar e da água e o hidrogênio $(\mathrm{H})$ da água. Estes constituem aproximadamente $95 \%$ do peso seco das plantas, restando pouco para o solo, onde se encontram os nutrientes minerais (Malavolta et al., 1974; Raij, 1991).

Relatam-se aqui as principais funções no cafeeiro dos elementos encontrados no solo e que são detectados por INAA, fertilidade do solo e análise foliar. Em alguns casos foi descrito brevemente sua dinâmica no solo e planta.

A importância do cobalto $(\mathrm{Co})$ e sódio $(\mathrm{Na})$ também será descrita. Embora não considerados nutrientes essenciais, estes dois elementos possuem funções nas plantas e são determinados por INAA.

Outros elementos, bromo $(\mathrm{Br})$, césio $(\mathrm{Cs})$, rubídio $(\mathrm{Rb})$ e escândio $(\mathrm{Sc})$, embora não possuam papel fisiológico conhecido em plantas (Markert, 1998), são determinados por INAA e suas quantificações nos diferentes compartimentos (grãos, folhas e solo) podem ser úteis para diferenciar-se os dois sistemas de produção.

\section{N - Nitrogênio}

O nitrogênio é bastante móvel nas plantas de café e no solo (Raij, 1991). É importante na expansão da área foliar, crescimento da vegetação e formação de botões florais, sendo constituinte dos aminoácidos (proteínas) e localizado principalmente nos cloroplastos das folhas, portanto vital para a fotossíntese. É o nutriente mais exigido pelas culturas, entretanto no caso do café é pouco superior ao K (Matiello et al., 2002; Malavolta,1986). Este elemento possui uma dinâmica complexa. No ar, está presente na 
forma estável de $\mathrm{N}_{2}$, não aproveitável pela maioria das culturas. Quando não fornecido $\mathrm{N}$ através de adubações, este é basicamente absorvido por dois mecanismos. O primeiro é a transformação do $\mathrm{N}_{2}$ em óxidos por descargas elétricas na atmosfera. Esses óxidos são convertidos em ácido nítrico, que chegam ao solo através das chuvas, resultando em nitratos que são aproveitados pelas plantas. $O$ segundo é a fixação biológica, onde a ligação existente entre os dois átomos de $\mathrm{N}$ é quebrada e o nitrogênio é hidrogenado a amônio, que é incorporado ao metabolismo do organismo fixador e aprisionado nas cadeias dos compostos orgânicos. Pode se dar por microrganismos livres (bactéria Azobacter e Beijerinckia). De maior importância agrícola são as bactérias do gênero Rhizobium, que formam nódulos nas raízes de leguminosas e transferem o nitrogênio fixado do ar, transformando em formas metabolizáveis, para a planta hospedeira, em quantidades consideráveis (Pritchett \& Fisher, 1985; Raij, 1991).

\section{K - Potássio}

Assim como o N, o K também é bastante móvel nos cafeeiros e no solo (Mills \& Jones, 1997; Raij, 1991). Este influi na atividade enzimática, na síntese e transporte dos carboidratos, sendo esta última função particularmente importante durante o período de enchimento de grãos. Com deficiência de $\mathrm{K}$, o crescimento diminui pois os açúcares e amidos acumulam-se onde são formados. É regulador da turgescência e melhora a resistência a pragas e doenças, bem como à seca e ao frio (Matiello et al.,2002; Mills \& Jones, 1997). É o segundo macronutriente em valor contido na planta e no caso do café é muito próximo ao N. Muito abundante em rochas e solos, sendo que em solos bem supridos, supera $1 \%$. O K é absorvido pelas plantas da solução do solo na forma iônica de $\mathrm{K}^{+}$. Este depende da difusão para chegar à raízes, sendo que os sais de potássio apresentam alta solubilidade podendo assim atingir altos concentrações de $\mathrm{K}^{+}$na solução do solo. Isto lhe confere uma alta mobilidade no solo, permitindo também um esgotamento mais fácil. A diminuição da água no solo afeta a difusão deste elemento, dificultando sua absorção. A maior parte do $\mathrm{K}$ é absorvida pelas plantas durante o crescimento vegetativo. É absorvido como $\mathrm{K}^{+}$, mantendo-se sempre nesta forma. Pode ser absorvido pelas plantas das camadas mais profundas (Raij, 1991). 


\section{P - Fósforo}

O P é bastante móvel nas plantas de café, entretanto de baixíssima mobilidade no solo (Mills \& Jones, 1997; Raij, 1991). Influi na síntese e armazenamento de energia, compondo a ATP (Adenosina Trifosfato) (Matiello et al., 2002; Mills \& Jones, 1997). É o macronutriente exigido em menores quantidades, porém o mais utilizado em adubação devido a carência em solos nacionais e a forte fixação pelo solo. As plantas absorvem o P da solução do solo. Embora o P seja classificado como um macronutriente primário e de grande importância na adubação, suas concentrações nas plantas são bem mais baixas que as de $\mathrm{N}$ e K. O P é um elemento pouco móvel no solo (Mills \& Jones, 1997; Raij, 1991). Além disto, na maioria das vezes, encontra-se insolúvel no solo, ou seja em formas não aproveitáveis para as plantas. Quando na solução do solo, está acessível æ̀ plantas, existindo também o P lábil e o P não lábil. O P lábil pode ser convertido para a solução do solo. Existe uma constante reposição do $\mathrm{P}$ na solução do solo pelo $\mathrm{P}$ lábil, ou seja, a medida que o $\mathrm{P}$ da solução vai sendo absorvido pela planta ou perdido por lixiviação, há uma dissolução do P lábil. O método de extração utilizado no presente estudo (Resina) reproduz esta mesma situação, avaliando o P da solução do solo e o P lábil. O P não lábil, é constituído de compostos insolúveis e muito lentamente estes podem transformar-se em P lábil.

\section{Ca - Cálcio}

O Ca é pouco móvel nas plantas e bastante móvel no solo. Influi na estruturação e sistema radicular, principalmente como componente das paredes celulares (Raij, 1991; Markert, 1998). Inibe a ação da poligaracturonase (enzima pectolítica de fungos patogênicos) conferindo maior resistência das plantas aos fungos (Marschner, 1995).

\section{Mg - Magnésio}

O Mg é bastante móvel nas plantas e no solo. É o elemento central da molécula da clorofila, possuindo, portanto, função essencial no metabolismo energético das plantas (Matiello et al., 2002; Raij, 1991).

\section{Zn - Zinco}

Com baixa mobilidade nas plantas, o $\mathrm{Zn}$ atua como catalisador na formação do triptofano, precursor do ácido indol acético, hormônio responsável pelo crescimento da parte aérea do cafeeiro (Matiello et al., 2002). É necessário para a formação da clorofila (Markert, 
1998). Em sedimentos argilosos encontram-se em maior quantidade que em solos arenosos. Em solos mundiais, os valores oscilam de $17 \mu \mathrm{g} / \mathrm{g}$ a 125 $\mu \mathrm{g} / \mathrm{g}$ (Raij, 1991).

\section{$\mathrm{Cu}$ - Cobre}

Em plantas e solos é pouco móvel, além de ser muito retido pela matéria orgânica. Participa nos processos de respiração e de oxidação como catalisador (Mills \& Jones, 1997;

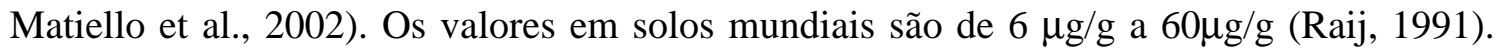
Em plantas com deficiência foram observados redução do metabolismo de fenóis, acúmulo de carboidratos e senescência precoce (Marschner, 1995).

\section{Mn - Manganês}

O Mn é prejudicial quando em excesso, estando associado a solos ácidos (Matiello et al., 2002). É um dos micronutrientes mais comuns na litosfera, apresentando valores em solos mundiais de $10 \mu \mathrm{g} / \mathrm{g}$ a $9000 \mu \mathrm{g} / \mathrm{g}$ (Raij, 1991). Uma das funções do manganês nas plantas é como co-fator de aproximadamente 35 enzimas diferentes. Esse nutriente afeta a fenilalanina amônia liase (PAL - genes de defesa inespecífico nas plantas) e estimula peroxidases requeridas na biossíntese de lignina, componente importante na resistência das plantas (Marschner, 1995). Também participa na síntese do ácido nucléico (Markert, 1998).

\section{Fe - Ferro}

Sua deficiência é causada por má drenagem e/ou excesso de matéria orgânica

(Matiello et al., 2002). É o elemento metálico mais comum na crosta terrestre cujo comportamento está ligado à ciclagens de $\mathrm{O}, \mathrm{S}$ e C. Seus valores em solos mundiais oscilam de 0,5 \% a 5\%. No Brasil são mais elevados, sendo superiores a 10\%. (Raij, 1991). Possível efeito na ativação de enzimas necessárias à síntese de compostos antifúngicos (Zambolin \& Ventura, 1993). Também atua na síntese de clorofila (Markert, 1998).

\section{Co}

O Cobalto é parte da vitamina $B_{12}$. Possui função enzimática (Markert, 1998).

\section{$\mathrm{Na}$}

Função eletroquímica como ativador enzimático (Markert, 1998). 


\subsection{Qualidade do café}

A procura por qualidade em produtos alimentícios tem mostrado um crescimento constante na última década, fruto de mudanças nas preferências dos consumidores. Muitos estão dispostos a pagar mais por produtos que possuam atributos desejados, que podem incluir parâmetros tangíveis ou intangíveis (Saes, 2001). O consumo e a exigência por cafés de qualidade, tanto no mercado externo quanto no mercado interno são cada vez mais comuns (Teixeira, 1998).

Theodoro (2001) sugere que em trabalhos futuros com qualidade de grãos café orgânico, realizem-se as classificações por tipo, peneira e classificação de bebida, através de análise sensorial.

O termo qualidade do café pode ser definido como um conjunto de atributos físicos, químicos, sensoriais e de segurança que atendam os gostos dos diversos tipos de consumidores. Para se investigar a qualidade total do café, devem-se levar em consideração os fatores edafo-climáticos regionais, espécies e variedades cultivadas, o manejo no período de pré-colheita (adubações, agroquímicos, sombra, etc...), de colheita (café colhido no pano, no chão, varreção) e de pós-colheita (tipo e qualidade de processo de secagem e processamento) (Pereira, 1999).

A diferenciação de cafés gourmet e de origem certificada tem como base atributos físicos e sensoriais, como qualidade da bebida superior ao padrão (Souza, 2001).

Sabor e aroma são dependentes da composição original dos grãos e são atributos que determinam a qualidade da bebida na prova de xícara.

A qualidade do café no Brasil é determinada principalmente através de três classificações: a) por tipo, separando-se os defeitos e impurezas; b) por peneira, separandose uma amostra de grãos por formato e tamanho; e c) pela prova de bebida, feita por provadores (Pereira, 1999). 


\section{MATERIAL E MÉTODOS}

\section{1 Área experimental}

O experimento foi instalado em fazenda produtora de café orgânico, localizada no município de Machado, sul de Minas Gerais, certificada desde 1991 pela Associação de Agricultura Orgânica (AAO) e desde 1999 pelo Instituto Biodinâmico de Desenvolvimento Rural (IBD). A Fazenda Jacarandá situa-se numa altitude de 1000 m a 1200 m, com precipitação média anual de $1200 \mathrm{~mm}$ e temperaturas mínimas de até $0^{\circ} \mathrm{C}$ no inverno, caracterizando um clima típico de montanhas. A área experimental está localizada a $1100 \mathrm{~m}$ de altitude e é composta por plantas de café variedade Mundo Novo, com espaçamento de 4,0 m x 2,0 m (1250 plantas/ha) e idade de 18 anos. O sombreamento é proporcionado por árvores adultas (mais de 40 anos) de Platycyamus regnellii, uma espécie leguminosa nativa da região, comumente chamada "pau pereira". Tais árvores medem aproximadamente $15 \mathrm{~m}$ de altura e possuem copa com cerca de $10 \mathrm{~m}$ de diâmetro. O solo é argissolo eutrófico e o relevo movimentado. 


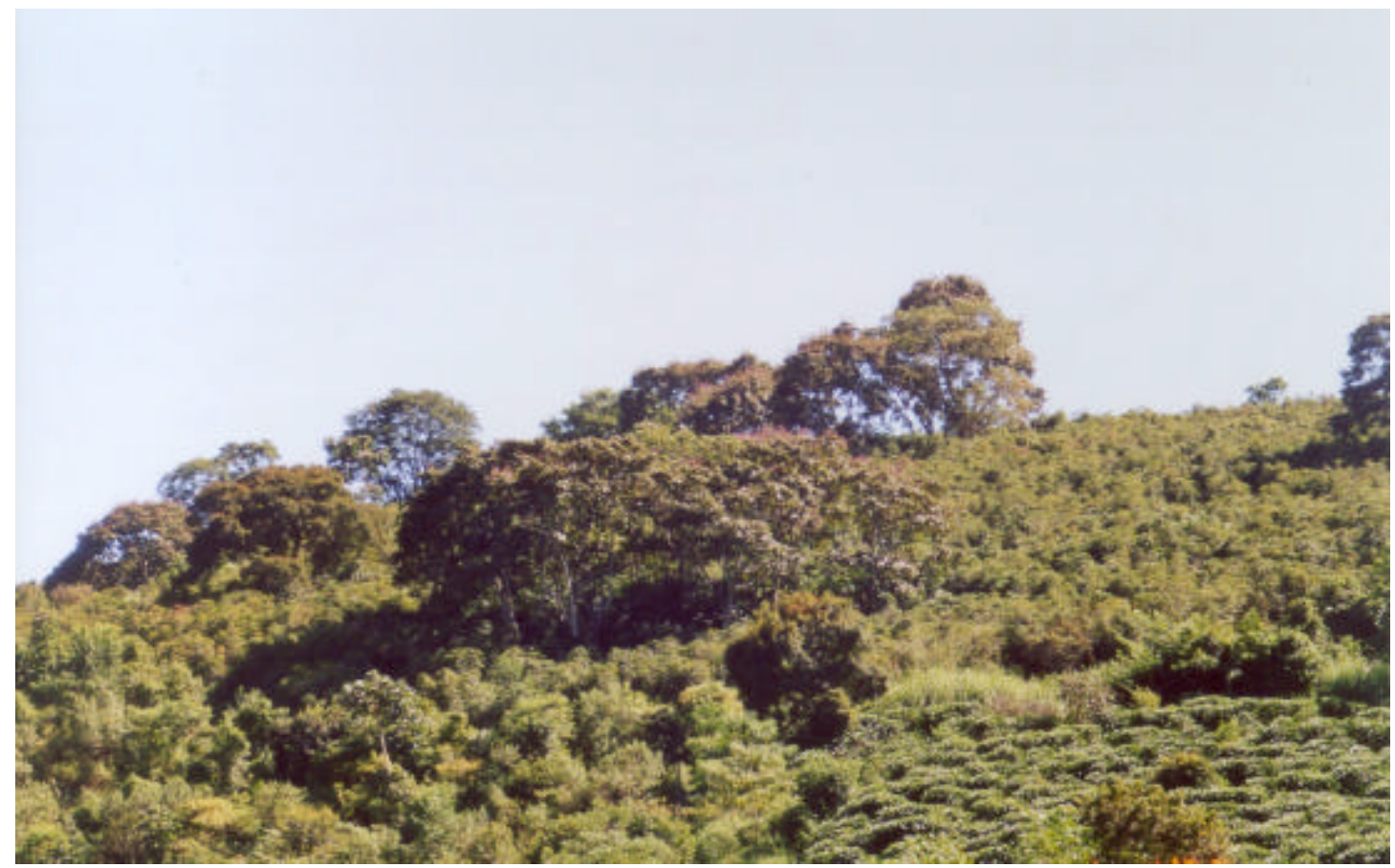

Figura 1 - Vista da área experimental na Fazenda Jacarandá, Machado-MG

\subsection{Delineamento Experimental}

O delineamento experimental utilizado foi parcelas subdivididas no espaço, uma vez que o ambiente é heterogêneo (declivoso). Selecionaram-se três blocos, cada um contendo uma árvore de Platycyamus regnellii no centro.

Os dois tratamentos primários foram: sombreado - pés de café localizados desde o limite do tronco da árvore até 3 metros de distância da copa e pleno sol - mais de 10 metros de distância da copa da árvore). Os subtratamentos consideraram a posição norte, sul, leste e oeste (4 pontos cardeais) em relação àárvore (Fig. 2). O experimento totalizou 24 parcelas ou 24 unidades amostrais. Cada parcela foi composta por duas plantas de café.

O Quadro 1 apresenta a descrição do delineamento experimental realizado e as parcelas 


\begin{tabular}{|c|c|c|c|}
\hline \multicolumn{4}{|c|}{ Parcelas } \\
\hline Número & Bloco & Tratamento & Cardeal \\
\hline 1 & $\mathrm{I}$ & Sombreado & Norte \\
\hline 2 & $\mathrm{I}$ & Sombreado & Sul \\
\hline 3 & $\mathrm{I}$ & Sombreado & Leste \\
\hline 4 & I & Sombreado & Oeste \\
\hline 5 & $\mathrm{I}$ & Pleno sol & Norte \\
\hline 6 & $\mathrm{I}$ & Pleno sol & Sul \\
\hline 7 & $\mathrm{I}$ & Pleno sol & Leste \\
\hline 8 & $\mathrm{I}$ & Pleno sol & Oeste \\
\hline 9 & II & Sombreado & Norte \\
\hline 10 & II & Sombreado & Sul \\
\hline 11 & II & Sombreado & Leste \\
\hline 12 & II & Sombreado & Oeste \\
\hline 13 & II & Pleno sol & Norte \\
\hline 14 & II & Pleno sol & Sul \\
\hline 15 & II & Pleno sol & Leste \\
\hline 16 & II & Pleno sol & Oeste \\
\hline 17 & III & Sombreado & Norte \\
\hline 18 & III & Sombreado & Sul \\
\hline 19 & III & Sombreado & Leste \\
\hline 20 & III & Sombreado & Oeste \\
\hline 21 & III & Pleno sol & Norte \\
\hline 22 & III & Pleno sol & Sul \\
\hline 23 & III & Pleno sol & Leste \\
\hline 24 & III & Pleno sol & Oeste \\
\hline
\end{tabular}

Quadro 1 - Descrição das 24 parcelas 


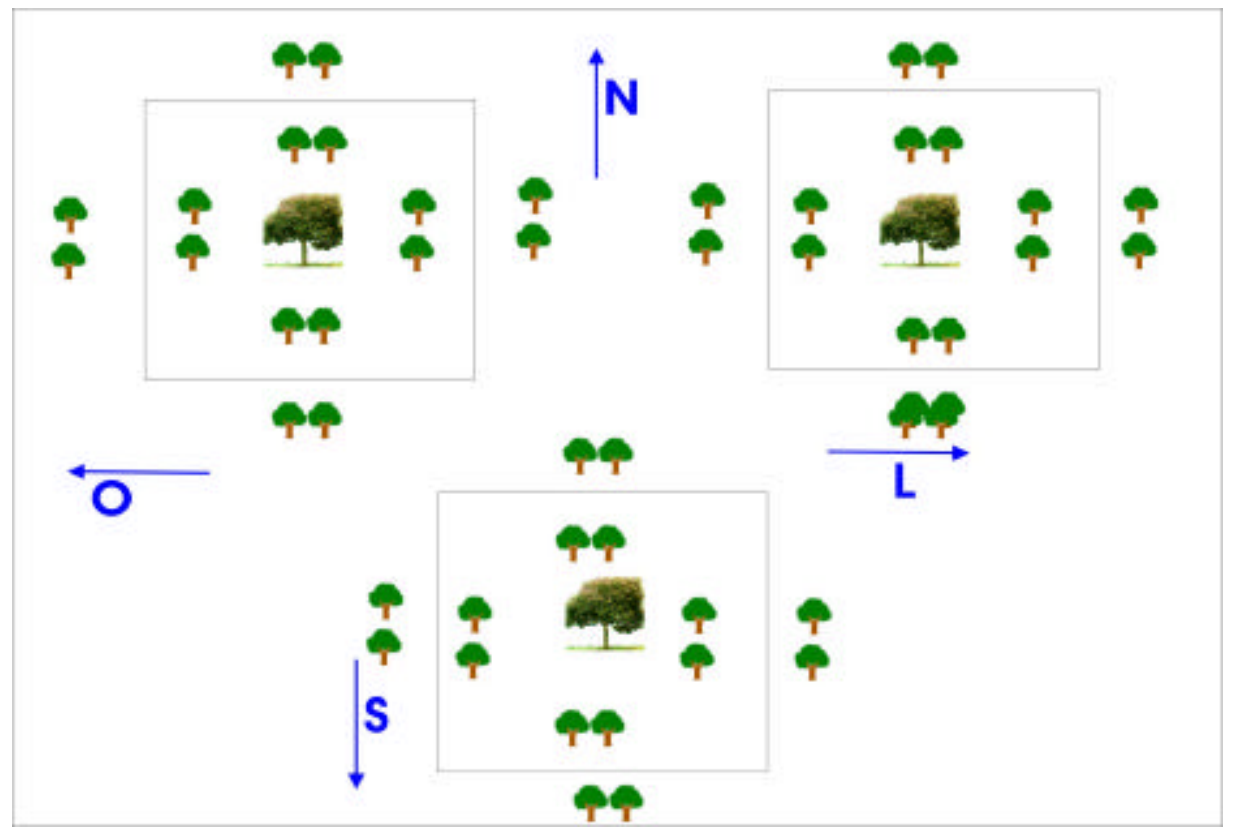

Figura 2 - Croqui da área experimental, mostrando os 3 blocos e as 24 parcelas

Para a distinção entre os dois tratamentos, foram avaliadas a temperatura do solo e a radiação solar incidente no solo dos sistemas sombreado e a pleno sol. Como referência, foi avaliada uma área de café intensamente sombreada.

A temperatura do solo foi medida no solo do meio da linha de cultivo do café com um termômetro de solo $\left(\right.$ Testo $^{\circledR}$ ) com princípio par termo elétrico inserido em 3 diferentes profundidades $(5 \mathrm{~cm}, 10 \mathrm{~cm} \mathrm{e} 15 \mathrm{~cm})$ de cada sistema, em três dias distintos $(23 \mathrm{e}$ 24/09/2003 e 03/10/2003) e em três horários (09:00, 12:00 e 16:00).

A intensidade de radiação solar incidente no solo foi medida com um sensor de radiação quântica através LI-1400 Data Logger (LI-COR ${ }^{\circledR}$ ), na superfície do solo dos sistemas, concomitantemente com as leituras de temperatura de solo, em dias ensolarados. Os valores encontrados estão expressos em $\mu \mathrm{mol}$ de fótons $\mathrm{m}^{-2} \mathrm{~s}^{-1}$.

\section{3 Árvore de sombreamento}

A árvore utilizada foi a espécie vegetal Platycyamus regnellii Benth, pertencente à família Leguminosae-Papilionideae. É comumente chamada pau-pereira, pereiro, pereira, folha de bolo, mangalô (RJ), angelim-rosa, camará-de-bilro, cataguá, pereira-vermelha, ubú- 
açu, jacatupé, pau-pente, pau-pereira-amarela. Tem aproximadamente 10 a $20 \mathrm{~m}$ de altura com tronco de 40 a $60 \mathrm{~cm}$ de diâmetro. Suas folhas são trifoliadas com folíolos glabros na face superior e ferrugíneo-tormentosas na inferior.

Ocorre no sul da Bahia, Espírito Santo, Minas Gerais, Goiás e São Paulo, principalmente na floresta semidecídua de altitude, com uma madeira moderadamente pesada $\left(0,81 \mathrm{~g} / \mathrm{cm}^{3}\right)$, grã direita a irregular, resistente, superfície irregularmente lustrosa e de aspecto fibroso, de boa durabilidade mesmo sob condições adversas, com alburno distinto.

É uma planta decídua, heliófita, seletiva xerófita com características de terrenos acidentados e pedregosos da floresta semidecídua de altitude. Sua dispersão é ampla porém descontínua, ocorrendo tanto nas formações secundárias como na floresta primária densa. Produz anualmente grande quantidade de sementes férteis que são facilmente disseminadas pelo vento. Esta espécie vegetal floresce durante os meses de fevereiro a abril. Os frutos iniciam a maturação em agosto com a planta totalmente destituída da folhagem, prolongando-se até o final de setembro (Lorenzi, 1998).

\subsection{Coleta de amostras}

As coletas das amostras foram realizadas em dias diferentes. As amostras de solo foram colhidas nos dias 2 e 3 de abril de 2002, enquanto a coleta de folhas de café e de folhas da árvore Platycyamus regnellii foi realizada nos dias 4 e 5 de abril de 2002.

Os frutos foram colhidos na época da maturação, que ocorre nos meses de maio a setembro. As datas das coletas foram os dias 21, 22 e 23 de junho de 2002.

\subsubsection{Coleta de solo}

A retirada das amostras de solo foi feita em 8 pontos distintos, 4 do lado superior e 4 do lado inferior da parcela, na projeção da copa do cafeeiro, a uma profundidade de $20 \mathrm{~cm}$, utilizando um amostrador próprio para coleta de solo, tipo sonda.

O solo foi homogeneizado e dividido em duas partes, uma destinada àINAA e outra para fertilidade do solo. 


\subsubsection{Coleta de folhas}

Em cada planta de café da parcela selecionada, foram coletados 4 pares de folhas situadas no terceiro nó dos ramos da porção mediana da planta, nos 4 pontos cardeais para INAA e análise foliar.

Foram coletadas também 6 amostras de folhas da espécie arbórea Platycyamus regnellii , sendo 2 de cada árvore do bloco, destinadas a INAA e análise foliar.

\subsubsection{Coleta de grãos de café}

Os frutos de café de cada parcela foram colhidos manualmente, derriçados no pano e os volumes quantificados nos mesmos dias da colheita. Foram secos ao sol, em peneiras individuais até atingir a umidade de $12 \%$, obtendo-se o café em coco (grãos de café com umidade entre 12 e $13 \%$ com casca).

\subsection{Preparo das amostras}

\subsubsection{Preparo das amostras para INAA}

O preparo das amostras foi conduzido no Laboratório de Radioisótopos (LRi) do CENA/USP - Piracicaba, SP.

\subsubsection{Preparo das amostras de grãos de café para INAA}

As amostras de grãos de café foram trazidas em coco para o LRi e descascadas com "Descascador Renda para Café" marca Pinhalense, obtendo-se o café beneficiado tipo bica corrida. As amostras foram secas em estufa a $60^{\circ} \mathrm{C}$ até peso constante e em seguida desintegradas em moinho com câmaras de alumina sinterizada (evitando assim, contaminação metálica das amostras), atingindo tamanho de partículas inferior a $75 \mu \mathrm{m}$. Porções analíticas com aproximadamente $350 \mathrm{mg}$ foram colocadas em cápsulas de polietileno especial para irradiação (Vrije Universiteit, Amsterdã). Os materiais de 
referência certificados SRM 1515 (Apple Leaves) e RM 8433 (Corn Bran), fabricados pelo National Institute of Standards and Technology (NIST), EUA, foram utilizados para controle da qualidade analítica.

\subsubsection{Preparo das amostras de folhas para INAA}

As amostras de folhas para INAA foram lavadas com água bidestilada e secas em estufa a $60^{\circ} \mathrm{C}$ até atingirem peso constante. Foram desintegradas em moinho com câmaras de alumina sinterizada, obtendo tamanho de partículas inferior a $75 \mu \mathrm{m}$. Em seguida, porções analíticas com aproximadamente $150 \mathrm{mg}$ foram colocadas em cápsulas de polietileno especial para irradiação. Utilizaram-se dos materiais de referência certificados SRM 1515 (Apple Leaves) e RM 8433 (Corn Bran) para controle da qualidade analítica.

\subsubsection{Preparo das amostras de solo para INAA}

As amostras de solo foram secas em estufa a $80^{\circ} \mathrm{C}$ até atingirem peso constante. Foram, então, moídas em gral de porcelana, peneiradas, atingindo tamanho de partículas inferior a $75 \mu \mathrm{m}$ e homogeneizadas. Em seguida, porções analíticas com aproximadamente $250 \mathrm{mg}$ foram colocadas em cápsulas de polietileno especial para irradiação. O material de referência certificado "Soil 7", fabricado pelo International Atomic Energy Agency (IAEA), Áustria, foi utilizado para controle da qualidade analítica.

\subsubsection{Procedimento padrão para as amostras destinadas a INAA}

As massas das amostras de grãos, folhas e solo, foram quantificadas em balança analítica Mettler Toledo modelo AT20, com precisão de $2 \mu \mathrm{g}$ e repetibilidade de $4 \mu \mathrm{g}$, calibrada semestralmente por empresa credenciada junto ao Instituto Nacional de Metrologia, Normalização e Qualidade Industrial (INMETRO). O teor de água foi determinado por meio de duplicatas de $2 \mathrm{~g}$ tomadas durante o preenchimento das cápsulas. Em seguida, as cápsulas das amostras foram irradiadas no reator de pesquisa nuclear IEA- 
R1m, do Instituto de Pesquisas Energéticas e Nucleares (IPEN), São Paulo, sob um fluxo de nêutrons térmicos da ordem de $1 \times 10^{13} \mathrm{~cm}^{-2} \mathrm{~s}^{-1}$ por 8 horas. A radiação gama induzida foi medida em detector semicondutor de germânio hiperpuro (45\% de eficiência relativa no fotopico $1332 \mathrm{keV}$ do ${ }^{60} \mathrm{Co}$ ) fabricado pela EG\&G ORTEC, após 3, 7, 20 e 28 dias de decaimento radioativo, no Laboratório de Radioisótopos do CENA/USP, em Piracicaba SP. Os cálculos das concentrações dos elementos químicos foram efetuados utilizando-se do programa Quantu (Bacchi, 2001), que se baseia no método $\mathrm{k}_{0}$. O fluxo de nêutrons foi estimado por meio de fios de níquel-cromo de composição estabelecida (França, 2003). Os materiais de referências certificados foram analisados juntamente com as amostras para controle de qualidade analítica.

Os valores das quantidades dos elementos químicos determinados na amostra deveriam ser expressos como fração de massa, para atender ao Sistema Internacional de Unidades (SI). Contudo, na prática ainda são comumente expressos como concentração (apesar de esta representar massa/volume). Adota no presente caso o termo concentração para os resultados obtidos.

\subsubsection{Preparo das amostras de solo para fertilidade, pH e matéria orgânica}

Para análise de fertilidade do solo, pH e matéria orgânica, as amostras de solo foram homogeneizadas e secas a temperatura ambiente e enviadas para o Laboratório de Fertilidade do Solo do CENA/USP, que adota a metodologia padrão IAC (Raij \& Quaggio, 1983)

Foram realizadas determinações de $\mathrm{P}, \mathrm{Ca}, \mathrm{Mg}, \mathrm{K}, \mathrm{Al}+\mathrm{H}, \mathrm{Cu}, \mathrm{Fe}, \mathrm{Mn}$ e $\mathrm{Zn}$, além de matéria orgânica e pH.

\subsubsection{Preparo das amostras para análise foliar}

As amostras das folhas para análise foliar foram embaladas em sacos de papel e também enviadas para o Laboratório de Fertilidade do Solo do CENA/USP, utilizando metodologias propostas por Miyazawa et al. (1984, 1992), Krug, (1996) e Sarruge \& Haag, (1974) para determinação dos elementos N, P, K, Ca, Mg, S, Cu, Fe, Mn e Zn. 


\subsubsection{Preparo dos grãos de café para determinação da qualidade da bebida de café}

Foi enviado uma amostra de cerca de $1 \mathrm{~kg}$ de café em coco de cada parcela ao Laboratório de Classificação e Degustação de Café do Ministério da Agricultura, Pecuária e Abastecimento (MAPA-RJ), Rio de Janeiro - RJ, onde realizaram-se as análises de qualidade do café.

Para avaliar a qualidade da bebida foi realizada a prova de xícaras. As amostras foram submetidas à "prova de xícara", feita por profissionais treinados, seguindo-se o procedimento descrito a seguir.

O café foi beneficiado e torrado (torração americana) ${ }^{1}$ em torrador rotativo do tipo ROD-BEL e moído em moinho especial, apresentando granulação mais grossa e colocado em xícaras de louça.

A infusão foi preparada na proporção de $9 \mathrm{~g}$ de pó para $90 \mathrm{~mL}$ de água, sendo colocada sobre o pó, quando em ponto de primeira fervura. Mexeu-se a infusão com uma concha de prata e, nessa oportunidade, os classificadores/provadores cheiraram a infusão, a fim de obter um julgamento preliminar, baseado nos vapores desprendidos, que propiciam indicações sobre a qualidade da bebida.

A degustação final foi feita depois que o pó se depositou no fundo da xícara. Para facilitar esse resfriamento, as mesas de prova são giratórias e cada degustador habilita-se a uma temperatura específica para sua prova.

Com o auxílio de uma concha, o degustador retira uma porção de café da parte superior da infusão, que é levada, de forma ligeiramente inclinada, ao seu lábio inferior. Nesta posição, executa uma forte sucção, para que o líquido penetre em sua boca em forma de "spray" (mistura com ar) atingindo toda cavidade bucal e ativando o sentido do paladar, e, de imediato, devolve a quantidade sorvida àcuspideira.

Os provadores foram degustando e definindo a qualidade de cada amostra, registrando no cartão respectivo a classificação da bebida (Quadro 2) e as observações

\footnotetext{
${ }^{1}$ Torração americana (de preferência americana um pouco escura: “Torração de classificação", ao contrário da torração de consumo que é marrom escura). Essa torração faz com que todos os fatores que interferiram na condução do café, a partir da colheita, aflorem e permitam a sua fiel e detalhada classificação como produto final.
} 
necessárias. Ao passar de uma xícara para outra, os provadores lavaram a colher nas xícaras de água quente e fria, a fim de não contaminar a xícara seguinte.

\begin{tabular}{|l|l|}
\hline \multicolumn{1}{|c|}{ Classificação } & \multicolumn{1}{c|}{ Características } \\
\hline Estritamente Mole & Bebida de sabor suavíssimo e adocicado \\
\hline Mole & Bebida de sabor suave, acentuado e adocicado \\
\hline Apenas Mole & Bebida de sabor suave, porém com leve adstringência \\
\hline Dura & Bebida de sabor adstringente, gosto áspero \\
\hline Riada & Bebida com leve sabor de iodofórmio ou ácido fênico \\
\hline Rio & $\begin{array}{l}\text { Bebida com sabor forte e desagradável, lembrando } \\
\text { iodofórmio ou ácido fênico }\end{array}$ \\
\hline Rio zona & Bebida de sabor e odor intoleráveis ao paladar e ao olfato \\
\hline
\end{tabular}

Quadro 2 - Classificação do café (Coffea arabica L.) quanto àbebida

\subsubsection{Classificação dos grãos de café quanto à peneira}

Outra característica de qualidade do café cru considerada na comercialização, é a classificação por peneira / tamanho das favas.

Fava - São os grãos destacados dos frutos pelo beneficiamento. São classificadas pela sua forma e tamanho. Quanto àforma são denominados chatos e mocas.

O grão chato, que representa $85 \%$ a $90 \%$ da produção de café arábica, é resultante do desenvolvimento normal dos frutos. O seu comprimento é sempre maior do que a largura, com o dorso convexo e a parte ventral plana ou levemente côncava, com uma ranhura central disposta longitudinalmente.

O grão moca representa aproximadamente $10 \%$ do café arábico. Tem forma arredondada, mais comprido do que largo, afinado em suas extremidades, com ranhura central em sentido longitudinal. Esta fava é resultante da fecundação de um único óvulo em uma das lojas do fruto, com o conseqüente desenvolvimento de apenas um grão que ocupa todo o espaço do fruto tomando o formato descrito. As favas são classificadas em graúda, boa, média ou miúda.

Peneira - Baseando nas dimensões e na forma dos grãos, o café classifica-se em chato-grosso, médio, miúdo, moca-graúdo, médio e miúdo, quebrado e mínimas.

Classificação oficial por peneiras dos grãos beneficiados pelas suas dimensões: 
- grão chato-grosso: peneiras 17 e maiores (café grande);

- grão chato-médio: peneiras 15 e 16 (café médio);

- grão chatinho: peneiras 12, 13 e 14 (café miúdo ou chatinho);

- grão moca-grosso: peneiras 11 e 13 (moca-grande) ;

- grão moca-médio: peneira 10 (moca-médio); e

- grão moquinha : peneiras 8 e 9 (moca miúdo ou moquinha).

A composição das peneiras utilizadas no presente trabalho foi a seguinte: 18 acima, $17,16,15,14,11,10,8$. Para se obter a composição em porcentagem do café em bica corrida, separam-se 100 gramas das amostras que foram passadas no conjunto de peneiras, dispostas de forma citada a seguir (Quadro 3).

\begin{tabular}{|l|l|l|l|l|l|}
\hline Peneira(s) & Forma & Fava & Peneira & Forma & Fava \\
\hline $19 / 20$ & Chato & graúda & 15 & Chato & Médio \\
\hline 13 & Moca & graúda & 9 & Moca & Miúdo ou moquinha \\
\hline 18 & Chato & graúda & 14 & Chato & Miúdo ou chatinho \\
\hline 12 & Moca & graúda & 8 & Moca & Miúdo ou chatinho \\
\hline 17 & Chato & graúda & 13 & Chato & Miúdo ou chatinho \\
\hline 11 & Moca & Médio & 12 & Chato & Miúdo ou chatinho \\
\hline 16 & Chato & Médio & 11 & Chato & Miúdo ou chatinho \\
\hline 10 & Moca & Médio & 10 & Chato & Miúdo ou chatinho \\
\hline & & & 9 & Chato & Miúdo ou chatinho \\
\hline
\end{tabular}

Quadro 3 - Ordem de colocação (montagem) das peneiras para a separação de um café bica corrida

O café que ficou retido em cada peneira foi cuidadosamente pesado e o resultado das pesagens já representa o percentual de cada uma delas.

\subsubsection{Procedimentos práticos realizados para a determinação do tipo de café}

O tipo do café é a caracterização dos defeitos atribuídos a uma amostra de café beneficiado. Ele é obtido através da visualização da amostra, contagem dos defeitos, correlação com a tabela de equivalência de defeitos (Anexo B) e correlação do número de defeitos com a tabela oficial de classificação (Anexo C). 
Em ambiente apropriado, os classificadores colocaram sobre uma cartolina preta opaca, a quantidade total da amostra a ser analisada. No relance da esparramação do café sobre a cartolina, os classificadores examinaram e obtiveram no "golpe de vista", com alguma margem de segurança, indicadores do tipo do café.

Com as observações feitas no "golpe de vista", tendo como referência os trezentos gramas de café que compõem a amostra e sempre trabalhando com ela exposta sobre a cartolina, os profissionais utilizaram os critérios citados no Quadro 4 para a separação dos defeitos e fixação do respectivo tipo.

\begin{tabular}{|l|l|l|}
\hline \multicolumn{1}{|c|}{ DO TIPO } & \multicolumn{1}{c|}{ AO TIPO } & QUANTIDADE EM GRAMAS \\
\hline 2(dois) & 3-4(três/quatro) & 300(TOTAL DA AMOSTRA) \\
\hline 3-4(três/quatro) & 5(cinco) & 150 \\
\hline 5(cinco) & 6-7(seis/sete) & 100 \\
\hline 6-7(seis/sete) & 8(oito) & 50 \\
\hline Tipo abaixo de & 8(oito) & 25(PARA CONFIRMAÇÃO) \\
\hline
\end{tabular}

Quadro 4 - Quantidade de café a ser catado numa amostra de 300 gramas considerando a impressão inicial pelo golpe de vista

Realizada a separação dos defeitos conforme sua categoria através da tabela de equivalência de defeitos (Anexo B), verificados os seus valores e o respectivo somatório, comparou-se este resultado com a tabela oficial de classificação (Anexo C), buscando-se na linha correspondente ao número de defeitos encontrados, ou na linha mais próxima, o tipo correspondente.

A classificação quanto ao tipo consiste, então, em determinar o número de grãos imperfeitos ou quantidade de impurezas contidas numa amostra de 300 gramas. Esta classificação apresenta sete tipos numerados de 2 a 8 (Quadro 5), bem como o número de pontos atribuídos aos tipos e a seus intermediários (Anexo C). 


\begin{tabular}{|c|c|}
\hline Tipos Exatos & Números de Defeitos \\
\hline 2 & 4 \\
\hline 3 & 12 \\
\hline 4 & 26 \\
\hline 5 & 46 \\
\hline 6 & 86 \\
\hline 7 & 160 \\
\hline 8 & 360 \\
\hline
\end{tabular}

Quadro 5 - Tipos exatos de café em função do número total de defeitos

\subsubsection{Análises estatísticas}

Os dados foram analisados estatisticamente por meio do programa SAS. Os testes univariados compreenderam a realização da análise da variância, aplicada para testar a hipótese de igualdade de composição química elementar entre os grãos de café, folhas de café e solo, bem como para fertilidade do solo, análise foliar do cafeeiro, qualidade da bebida, porcentagem de peneira acima de 14 dos grãos produzidos, tipo do café (em pontos), rendimento e quantidade de grãos verdes (em amostras de $300 \mathrm{~g}$ ) e produtividade do café, dos sistemas a pleno sol e sombreado. Foi aplicado o teste de Tukey para comparações múltiplas entre médias, em nível de $95 \%$ de confiança. Com relação à estatística multivariada, foi utilizada a análise de componentes principais (PCA) para a composição química elementar (CQE) obtida por INAA dos grãos de café, folhas de café e solo provenientes dos dois sistemas. 


\section{RESULTADOS E DISCUSSÃO}

\subsection{Dados de temperatura do solo e radiação solar}

Foram determinadas a temperatura do solo e a radiação solar emitida com o propósito de discriminar os dois sistemas estudados, sombreado e pleno sol. Os dados obtidos podem ser visualizados nas Tabelas 1 e 2 . As temperaturas estão expressas em graus Celsius $\left({ }^{\circ} \mathrm{C}\right)$ e as intensidades de radiação solar em $\mu \mathrm{mol} \mathrm{m} \mathrm{m}^{-2} \mathrm{~s}^{-1}$.

Tabela 1. Médias das temperaturas do solo em ${ }^{\circ} \mathrm{C}(0-15 \mathrm{~cm}$ profundidade $)$

\begin{tabular}{cccc}
\hline Horário e data & $\begin{array}{c}\mathbf{0 9 : 0 0}-\mathbf{1 0 : 0 0} \\
(\mathbf{2 4 / 0 9 / 2 0 0 3 )}\end{array}$ & $\begin{array}{c}\mathbf{1 2 : 0 0}-\mathbf{1 3 : 0 0} \\
\mathbf{( 0 3 / 1 0 / 2 0 0 3 )}\end{array}$ & $\begin{array}{c}\mathbf{1 5 : 3 0 - 1 6 : 3 0} \\
(\mathbf{2 3 / 0 9 / 2 0 0 3 )}\end{array}$ \\
\hline Tratamento & & & \\
Pleno Sol & 22,1 & 27,6 & 29,0 \\
Sombreado & 19,6 & 21,1 & 21,4 \\
Referência Sombreado & 19,4 & 19,6 & 20,5 \\
\hline
\end{tabular}

Tabela 2. Médias das intensidades de radiação solar expressas em $\mu \mathrm{mol} \mathrm{m} \mathrm{m}^{-2} \mathrm{~s}^{-1}$

\begin{tabular}{ccc}
\hline Horário e data & $\begin{array}{c}\mathbf{0 9 : 0 0 - 1 0 : 0 0} \\
(\mathbf{2 4 / 0 9 / 2 0 0 3 )}\end{array}$ & $\begin{array}{c}\mathbf{1 2 : 0 0 - 1 3 : 0 0} \\
(\mathbf{0 3 / 1 0 / 2 0 0 3 )}\end{array}$ \\
\hline Tratamento & & \\
Pleno Sol & 1033 & 1747 \\
Sombreado & 92,9 & 157 \\
Referência Sombreado & 42,8 & 68,5 \\
\hline
\end{tabular}


Os resultados obtidos foram eficientes para a distinção dos dois sistemas avaliados.

Pode-se notar que os valores de temperatura de solo no sistema a pleno sol foram sempre superiores aos encontrados no sistema sombreado, bem como os valores para radiação solar.

O Coffea arabica é uma espécie adaptada a climas amenos com temperaturas que variam entre $16^{\circ} \mathrm{C}$ e $23^{\circ} \mathrm{C}$. Temperaturas acima de $25^{\circ} \mathrm{C}$ causam comprometimento à fotossíntese (Clarke \& Macrae, 1985b; Pedini, 2000). A cada grau de temperatura aumentado acima dos $24^{\circ} \mathrm{C}$ há uma redução de $10 \%$ da taxa fotossintética (Matiello et al., 2002). De acordo com Matiello et al. (2002), as temperaturas consideradas ideais para o solo de cafeeiros situam-se entre $17^{\circ} \mathrm{C}$ e $27^{\circ} \mathrm{C}$. Estas faixas de temperatura puderam ser encontradas com mais freqüência no sistema sombreado indicando a sua viabilidade.

Com uma intensidade luminosa de $18 \mu \mathrm{mol} \mathrm{m} \mathrm{m}^{-2} \mathrm{~s}^{-1}$, as folhas do cafeeiro foram capazes de fotossintetizar ativamente, mas somente a $37 \mu \mathrm{mol} \mathrm{m} \mathrm{s}^{-1}$ a fotossíntese foi maior que a respiração, indicando que o ponto de compensação luminoso do cafeeiro está situado em torno de $30 \mu \mathrm{mol} \mathrm{m} \mathrm{m}^{-2} \mathrm{~s}^{-1}$ (Kumar \& Tieszen, 1976), embora o valor encontrado por Yamagushi \& Friend (1979) esteja próximo de $15 \mu \mathrm{mol} \mathrm{m} \mathrm{m}^{-2} \mathrm{~s}^{-1}$

\subsection{Resultados de produção das unidades amostrais}

As médias de produção por parcela, desvios padrões e o teste de Tukey para comparações múltiplas entre médias, em nível de 95\% de confiança estão apresentados na Tabela 3. Não houve diferença estatística significativa entre os dois sistemas. Entretanto o sistema sombreado apresentou produtividade ligeiramente maior que o a pleno sol. A Figura 3 ilustra graficamente os dados de produção obtidos.

Para obter os valores de produtividade foram realizados os seguintes cálculos:

Cálculo da produção em litros de café colhido por hectare:

$$
\mathrm{a}=\mathrm{b} X \mathrm{c}
$$

eq. 1

Cálculo da produção por hectare em sacas de $60 \mathrm{~kg}$ de café beneficiado:

$$
\mathrm{d}=\mathrm{a} / \mathrm{e}
$$

sendo que:

$\mathrm{a}=$ produção por hectare em litros de grãos de café quando colhido 
$\mathrm{b}=$ volume em litros de grãos de café por parcela quando colhido

$\mathrm{c}=$ quantidade de parcelas por hectare (1250 plantas por ha sendo duas plantas por parcela; valor de $\mathrm{c}=625$ )

$\mathrm{d}$ = produção por hectare em sacas de $60 \mathrm{~kg}$ de café beneficiado

e = volume em litros de grãos de café colhido que resultará em uma saca beneficiada de $60 \mathrm{~kg}$; valor de e $=480$

Tabela 3. Média e desvio padrão dos volumes produzidos (L) de café nos dois tratamentos estudados

\begin{tabular}{llc}
\hline Sombreado & & $\begin{array}{c}\text { Produção café colhido } \\
\text { (L) }\end{array}$ \\
\hline Bloco I & Média & 52,5 \\
& Desvio Padrão & 7,14 \\
Bloco II & Média & 13,0 \\
& Desvio Padrão & 4,76 \\
Bloco III & Média & 43,8 \\
& Desvio Padrão & 16,78 \\
Média sombreado (n=12) & & $36,4 \mathrm{a}$ \\
Desvio padrão & & 20,24 \\
Pleno Sol & & \\
Bloco I & Média & 34,8 \\
& Desvio Padrão & 16,64 \\
Bloco II & Média & 30,5 \\
& Desvio Padrão & 19,33 \\
Bloco III & Média & 36,5 \\
& Desvio Padrão & 23,53 \\
Média pleno sol (n=12) & & $33,9 \mathrm{a}$ \\
Desvio padrão & & 18,31 \\
\hline Médias seguidas pela mesma letra não diferem estatisticamente entre si pelo teste de Tukey em \\
nível de 95\% de confiança
\end{tabular}

Embora não tenha havido diferença estatística significativa entre os valores de produtividade, o sistema sombreado obteve uma produção média por hectare ligeiramente maior (47,39 sacas de $60 \mathrm{~kg}$ de café beneficiado/ha) do que o a pleno sol (44,14 sacas de 60 $\mathrm{kg}$ de café beneficiado/ha). Esta diferença de produtividade em favor do sistema sombreado também foi observada por Freitas et al. (2002), Hashizume et al. (1980), Rena et al. (1986) e Ricci et al. (2002). 
Trabalho realizado por Freitas et al. (2002) no sul de Minas Gerais, com café arábica, concluíram que aproximando-se da projeção da copa do ipê amarelo (Tabebuia serratifolia) houve um aumento na produção do café. Ricci et al. (2002) avaliaram o sombreamento de café conilon no estado do Rio de Janeiro com Gliricidia sepium e Erithrina variegata, ambas espécies florestais leguminosas. Fernandes (1986) relata experimento do antigo IBC (Instituto Brasileiro do Café) na serra do Baturité, Ceará, onde o café arábica sombreado com bananeiras obteve produtividade $50 \%$ superior ao café a pleno sol. Hashizume et al. (1980) avaliaram o sombreamento de café arábica no estado do Espírito Santo com bananeiras, obtendo maior produtividade nas parcelas sombreadas.

De acordo com dados da Fazenda Jacarandá, onde foi instalado o experimento, a produção média da propriedade na safra 2002 foi 25 sacas de $60 \mathrm{~kg}$ de café beneficiado por hectare, sendo inferior à média do experimento.

Os resultados de produtividade obtidos no presente experimento são considerados bons, sendo superiores à produção média nacional em 2002, de 14,7 sacas de $60 \mathrm{~kg}$ de café beneficiado por hectare (CONAB, 2002; Matiello et al., 2002). Resultados demonstraram que, neste caso, a produtividade do cafeeiro não foi prejudicada pelo sombreamento, ao contrário de alguns autores (Santinato et al., 2002; Miranda et al., 1999) que condenam a produção sombreada, pois diminuiria a produtividade por competição de nutrientes pelas espécies arbóreas ou mesmo através da pouca luz que incide sobre as plantações de café causando uma diminuição na fotossíntese e, portanto, da produtividade. Santinato et al. (2002) utilizaram para o sombreamento do café arábica a espécie florestal Grevillea robusta no sudoeste da Bahia. Em experimento relatado por Matiello et al. (2002) no sul de Minas Gerais, também com Grevillea robusta, foi demonstrada a redução na produção do cafeeiro.

Entretanto, deve-se considerar que a Grevillea robusta é uma espécie arbórea perenifólia (não perde suas folhas), enquanto o ipê amarelo utilizado por Freitas et al. (2002), a gliricídia (Ricci et al., 2002) e o pau pereira (utilizado neste experimento) são espécies caducifólias que perdem as folhas no período de seca e frio. Evidências práticas (observações de campo por agricultores) indicam que o cafeeiro precisa de sol no inverno, para que tenha uma indução floral e, consequientemente, uma florada intensa e boa produtividade. 
Em pesquisa realizada por Nunes et al. (1993) foi destacado a importância do sombreamento. Os autores concluíram que em ambientes com altas intensidades luminosas, além da saturação intensa do aparelho fotossintético do cafeeiro, houve também uma severa fotoinibição. A assimilação de carbono é maior em condições de sombreamento do que a pleno sol principalmente nos horários compreendidos entre 09:00 e 14:00. Este fato deve-se, provavelmente, ao fechamento dos estômatos provocado pela perda de água nessas condições (Nutman et al., 1937). Estudando os efeitos de 30\%, 50\% e $70 \%$ de sombreamento e $100 \%$ de luz solar em cultivares de Coffea arabica, Freitas (2000) verificou que o nível de sombreamento de $70 \%$ apresentou as maiores taxas de fotossíntese.

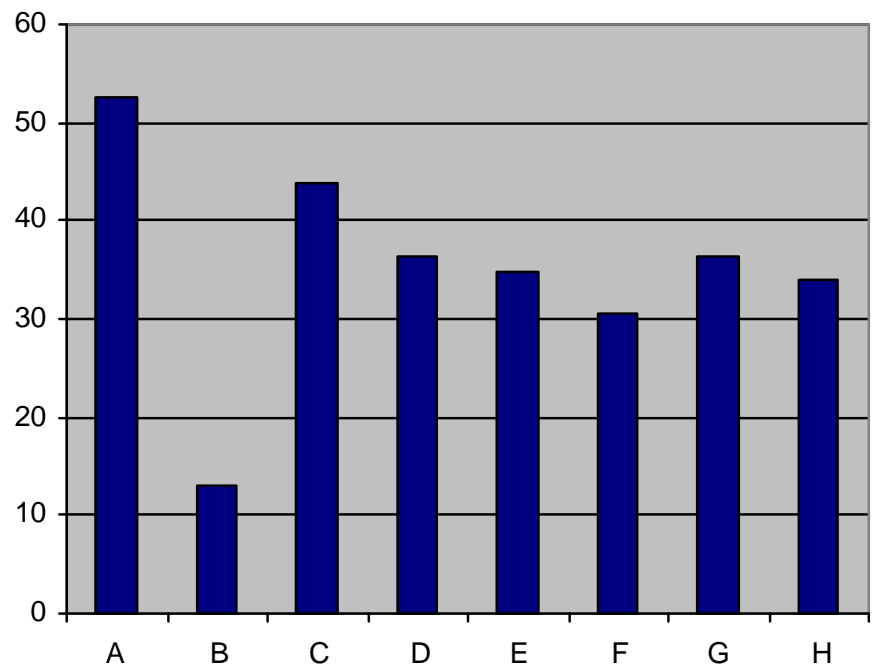

Figura 3 - Gráfico ilustrativo da produção de grãos de café em litros. A) Média das parcelas do bloco I do tratamento sombreado; B) Média das parcelas do bloco II do tratamento sombreado; C) Média das parcelas do bloco III do tratamento sombreado; D) Média geral da produção de grãos de café em litros colhidos das parcelas do tratamento sombreado; E) Média das parcelas do bloco I do tratamento a pleno sol; F) Média das parcelas do bloco II do tratamento a pleno sol; G) Média das parcelas do bloco III do tratamento a pleno sol; H) Média geral da produção de grãos de café em litros colhidos das parcelas do tratamento a pleno sol 


\subsection{Resultados da composição química elementar de grãos, folhas e solo}

\subsubsection{Resultados da composição química elementar de grãos de café}

Foram determinadas as concentrações de $\mathrm{Br}, \mathrm{Ca}, \mathrm{Co}, \mathrm{Cs}$, Fe, K, Na, $\mathrm{Rb}$ e $\mathrm{Zn}$ dos grãos de café dos dois sistemas. As médias das concentrações destes elementos, respectivos desvios padrões e o teste de Tukey para comparações múltiplas entre médias, em nível de 95\% de confiança, encontram -se na Tabela 4 . A figura 4 permite melhor visualização das médias dos sistemas de produção.

Tabela 4. Média das concentrações elementares e respectivos desvios padrões $\left(\mu \mathrm{g} \mathrm{g}^{-1}\right) \mathrm{de}$ grãos de café nos dois tratamentos estudados

\begin{tabular}{|c|c|c|c|c|c|c|c|c|c|c|}
\hline \multicolumn{2}{|c|}{ Sombreado } & \multirow{2}{*}{$\begin{array}{c}\mathbf{B r} \\
0,51\end{array}$} & \multirow{2}{*}{$\begin{array}{c}\mathbf{C a} \\
1220\end{array}$} & \multirow{2}{*}{$\begin{array}{c}\text { Co } \\
0,0253 \\
0,017\end{array}$} & \multirow{2}{*}{$\begin{array}{c}\text { Cs } \\
0,0321 \\
0,014\end{array}$} & \multirow{2}{*}{$\begin{array}{c}\mathbf{F e} \\
23,8 \\
3\end{array}$} & \multirow{2}{*}{$\begin{array}{c}\mathbf{K} \\
16800 \\
800\end{array}$} & \multirow{2}{*}{$\begin{array}{c}\mathbf{N a} \\
17,1 \\
13\end{array}$} & \multirow{2}{*}{$\begin{array}{c}\mathbf{R b} \\
33,9 \\
3\end{array}$} & \multirow{2}{*}{$\begin{array}{c}\mathbf{Z n} \\
6,70 \\
1,0\end{array}$} \\
\hline Bloco I & $\begin{array}{l}\text { Média } \\
\text { Desvio Padrão }\end{array}$ & & & & & & & & & \\
\hline Bloco II & $\begin{array}{l}\text { Média } \\
\text { Desvio Padrão }\end{array}$ & $\begin{array}{l}0,52 \\
0,07\end{array}$ & $\begin{array}{c}1010 \\
70\end{array}$ & $\begin{array}{c}0,0338 \\
0,008\end{array}$ & $\begin{array}{c}0,0282 \\
0,002\end{array}$ & $\begin{array}{c}27,3 \\
3\end{array}$ & $\begin{array}{c}15300 \\
800\end{array}$ & $\begin{array}{c}5,10 \\
0,9\end{array}$ & $\begin{array}{c}29,9 \\
2\end{array}$ & $\begin{array}{c}8,15 \\
0,9\end{array}$ \\
\hline Bloco III & $\begin{array}{l}\text { Média } \\
\text { Desvio Padrão }\end{array}$ & $\begin{array}{l}0,59 \\
0,05\end{array}$ & $\begin{array}{c}1180 \\
25\end{array}$ & $\begin{array}{c}0,0385 \\
0,008\end{array}$ & $\begin{array}{c}0,0488 \\
0,009\end{array}$ & $\begin{array}{c}22,5 \\
0,8\end{array}$ & $\begin{array}{c}16400 \\
600\end{array}$ & $\begin{array}{c}4,29 \\
0,8\end{array}$ & $\begin{array}{c}36,6 \\
1,8\end{array}$ & $\begin{array}{r}6,65 \\
0,4\end{array}$ \\
\hline \multicolumn{2}{|c|}{$\begin{array}{l}\text { Média sombreado }(\mathrm{n}=12) \\
\text { Desvio padrão }\end{array}$} & $\begin{array}{c}0,54 \mathrm{a} \\
0,06\end{array}$ & $\begin{array}{c}1140 \mathrm{a} \\
120\end{array}$ & $\begin{array}{c}0,03 \mathrm{a} \\
0,02\end{array}$ & $\begin{array}{c}0,036 \mathrm{a} \\
0,013\end{array}$ & $\begin{array}{c}24 \mathrm{a} \\
3\end{array}$ & $\begin{array}{l}16200 \mathrm{a} \\
900\end{array}$ & $\begin{array}{c}8,84 \mathrm{a} \\
9\end{array}$ & $\begin{array}{c}33,5 \mathrm{a} \\
4\end{array}$ & $\begin{array}{c}7,2 \mathrm{a} \\
1,0\end{array}$ \\
\hline \multicolumn{11}{|l|}{ Pleno Sol } \\
\hline Bloco I & $\begin{array}{l}\text { Média } \\
\text { Desvio Padrão }\end{array}$ & $\begin{array}{l}0,43 \\
0,13\end{array}$ & $\begin{array}{c}1210 \\
150\end{array}$ & $\begin{array}{c}0,0459 \\
0,016\end{array}$ & $\begin{array}{c}0,0471 \\
0,13\end{array}$ & $\begin{array}{c}24,0 \\
2\end{array}$ & $\begin{array}{c}15300 \\
1400\end{array}$ & $\begin{array}{c}7,55 \\
1,8\end{array}$ & $\begin{array}{c}32,8 \\
2\end{array}$ & $\begin{array}{r}7,37 \\
1,2\end{array}$ \\
\hline Bloco II & $\begin{array}{l}\text { Média } \\
\text { Desvio Padrão }\end{array}$ & $\begin{array}{c}0,85 \\
0,2\end{array}$ & $\begin{array}{c}966 \\
60\end{array}$ & $\begin{array}{c}0,0344 \\
0,02\end{array}$ & $\begin{array}{c}0,0345 \\
0,02\end{array}$ & $\begin{array}{c}24,7 \\
3\end{array}$ & $\begin{array}{c}15300 \\
800\end{array}$ & $\begin{array}{c}4,63 \\
0,6\end{array}$ & $\begin{array}{c}31,1 \\
4\end{array}$ & $\begin{array}{l}6,9 \\
1,0\end{array}$ \\
\hline Bloco III & $\begin{array}{l}\text { Média } \\
\text { Desvio Padrão }\end{array}$ & $\begin{array}{l}0,84 \\
0,15\end{array}$ & $\begin{array}{c}1070 \\
90\end{array}$ & $\begin{array}{c}0,0420 \\
0,02\end{array}$ & $\begin{array}{c}0,0508 \\
0,017\end{array}$ & $\begin{array}{c}23,0 \\
1,0\end{array}$ & $\begin{array}{c}14800 \\
1600\end{array}$ & $\begin{array}{c}3,61 \\
0,5\end{array}$ & $\begin{array}{c}32,7 \\
3\end{array}$ & $\begin{array}{c}6,59 \\
0,6\end{array}$ \\
\hline \multicolumn{2}{|c|}{$\begin{array}{l}\text { Média pleno sol }(\mathrm{n}=12) \\
\text { Desvio padrão }\end{array}$} & $\begin{array}{c}0,70 \mathrm{~b} \\
0,3\end{array}$ & $\begin{array}{c}1080 \mathrm{a} \\
140\end{array}$ & $\begin{array}{c}0,041 \mathrm{a} \\
0,019\end{array}$ & $\begin{array}{c}0,044 \mathrm{~b} \\
0,18\end{array}$ & $\begin{array}{c}24 \mathrm{a} \\
2\end{array}$ & $\begin{array}{c}15100 \mathrm{~b} \\
1200\end{array}$ & $\begin{array}{c}5,26 \mathrm{a} \\
2\end{array}$ & $\begin{array}{c}32 \mathrm{a} \\
3\end{array}$ & $\begin{array}{l}7 \mathrm{a} \\
0,9\end{array}$ \\
\hline
\end{tabular}

Médias seguidas pela mesma letra não diferem estatisticamente entre si pelo teste de Tukey em nível de $95 \%$ de confiança

Em dois estudos com grãos de café por meio de INAA (Krivan et al.,1993; Tagliaferro, 2002) foram obtidas concentrações elementares próximas æ̀ do pres ente estudo. Krivan et al. (1993) estudou a composição química de grãos de café verde da espécie arábica provenientes de diferentes países (Colômbia, Costa Rica, Cuba, El Salvador, México, Nicarágua, Panamá e Papua Nova Guiné), enquanto Tagliaferro (2002) analisou grãos de 
café verde da espécie arábica produzidos sob diferentes sistemas de manejo (orgânico e convencional) na região sul de Minas Gerais.

Valores similares de composição elementar de Coffea arabica foram obtidos por Martín et al (1998a, 1999) por espectrometria de emissão atômica (ICP-AES) e por Morgano (2002) por espectrometria de emissão ótica.

Analisando os resultados pela estatística univariada pode-se dizer que houve diferença estatística significativa pelo teste de Tukey em nível de 95\% de confiança para os elementos $\mathrm{Br}$, Cs e $\mathrm{K}$ entre os grãos produzidos nos sistemas a pleno sol e sombreado. $\mathrm{O}$ elemento $\mathrm{K}$ apresentou maior concentração no sistema sombreado, enquanto $\mathrm{Br}$ e $\mathrm{Cs}$ apresentaram maiores concentrações no sistema a pleno sol.

Por existir maior concentração de K no solo do sistema sombreado (resultados de fertilidade do solo, item 4.4) e ser um elemento muito móvel no solo e na planta (Raij, 1991), foi absorvido pela planta em maiores quantidades neste sistema. Quando há altas concentrações de $\mathrm{K}$ no solo, umidade e temperatura propícias, aumenta-se o movimento do $\mathrm{K}$ do solo para as raízes da planta. A permeabilidade da maioria das paredes celulares ao K explica a alta mobilidade deste nutriente pela planta toda (Mills \& Jones, 1997). Além disto, esta maior concentração de K nos grãos do sistema sombreado também pode ser atribuída à maior quantidade de raízes do cafeeiro, que irá explorar maior volume de solo e, consequientemente, absorver mais nutrientes. A maior quantidade de raízes do cafeeiro ocorre em sistemas de café sombreado, como resultado de uma menor temperatura do solo (Rena \& Maestri, 1986). 
$\mathrm{Br}$

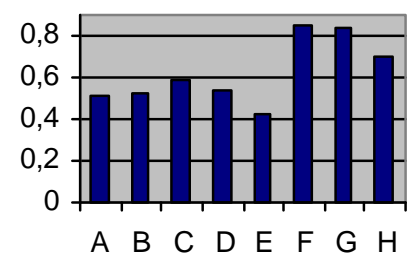

Cs

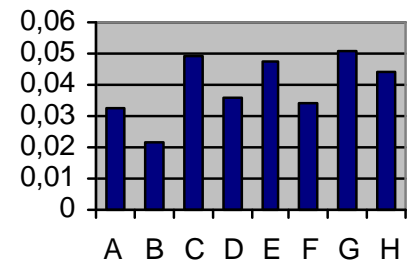

$\mathrm{Na}$

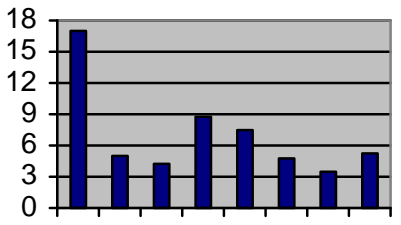

A B C D E F G H
$\mathrm{Ca}$

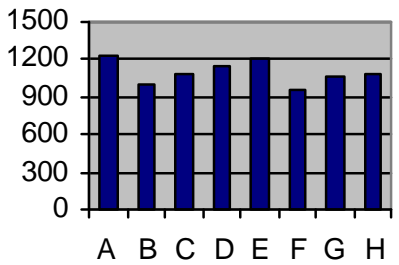

$\mathrm{Fe}$

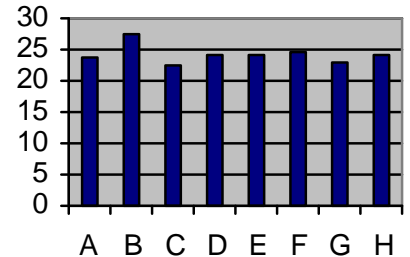

$\mathrm{Rb}$

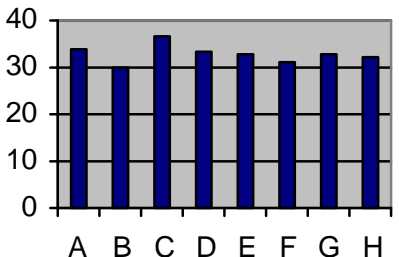

Co

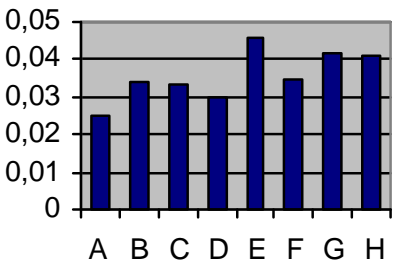

K

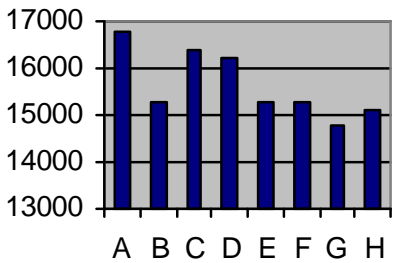

$\mathrm{Zn}$

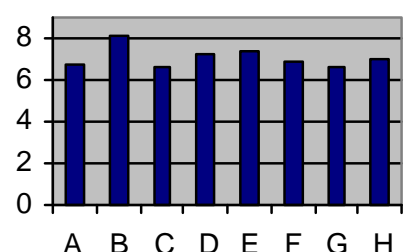

Figura 4 - Gráficos da composição química elementar média $\left(\mu \mathrm{g} \mathrm{g}^{-1}\right)$ em grãos de café.

A) Média das parcelas do bloco I do tratamento sombreado; B) Média das parcelas do bloco II do tratamento sombreado; C) Média das parcelas do bloco III do tratamento sombreado; D) Média geral das composições químicas elementares das parcelas do tratamento sombreado; E) Média das parcelas do bloco I do tratamento a pleno sol; F) Média das parcelas do bloco II do tratamento a pleno sol; G) Média das parcelas do bloco III do tratamento a pleno sol; H) Média geral das composições químicas elementares de todas as parcelas do tratamento a pleno sol 
Foi aplicada a estatística multivariada análise dos componentes principais aos resultados de concentração obtidos por INAA de $\mathrm{Br}, \mathrm{Ca}, \mathrm{Co}, \mathrm{Cs}, \mathrm{Fe}, \mathrm{K}, \mathrm{Na}, \mathrm{Rb}$ e $\mathrm{Zn}$ dos grãos de café. Utilizou-se da concentração dos elementos $\mathrm{Br}, \mathrm{Ca}, \mathrm{Cs}, \mathrm{K}, \mathrm{Rb}$ e $\mathrm{Zn}$, que apresentaram maior contribuição no processo discriminatório. A Figura 5 mostra o gráfico de dispersão com os dois primeiros componentes principais que respondem, respectivamente, por $36 \%$ e $27 \%$ da informação total. Com exceção de três amostras de café produzido a pleno sol (parcelas 5, 7 e 8, ver Anexo F), nota-se uma separação entre as duas categorias de café. Este resultado indica a possibilidade de discriminar cafés produzidos sob condições de pleno sol de cafés sombreados, baseando-se na análise química elementar praticada em elevado nível metrológico.

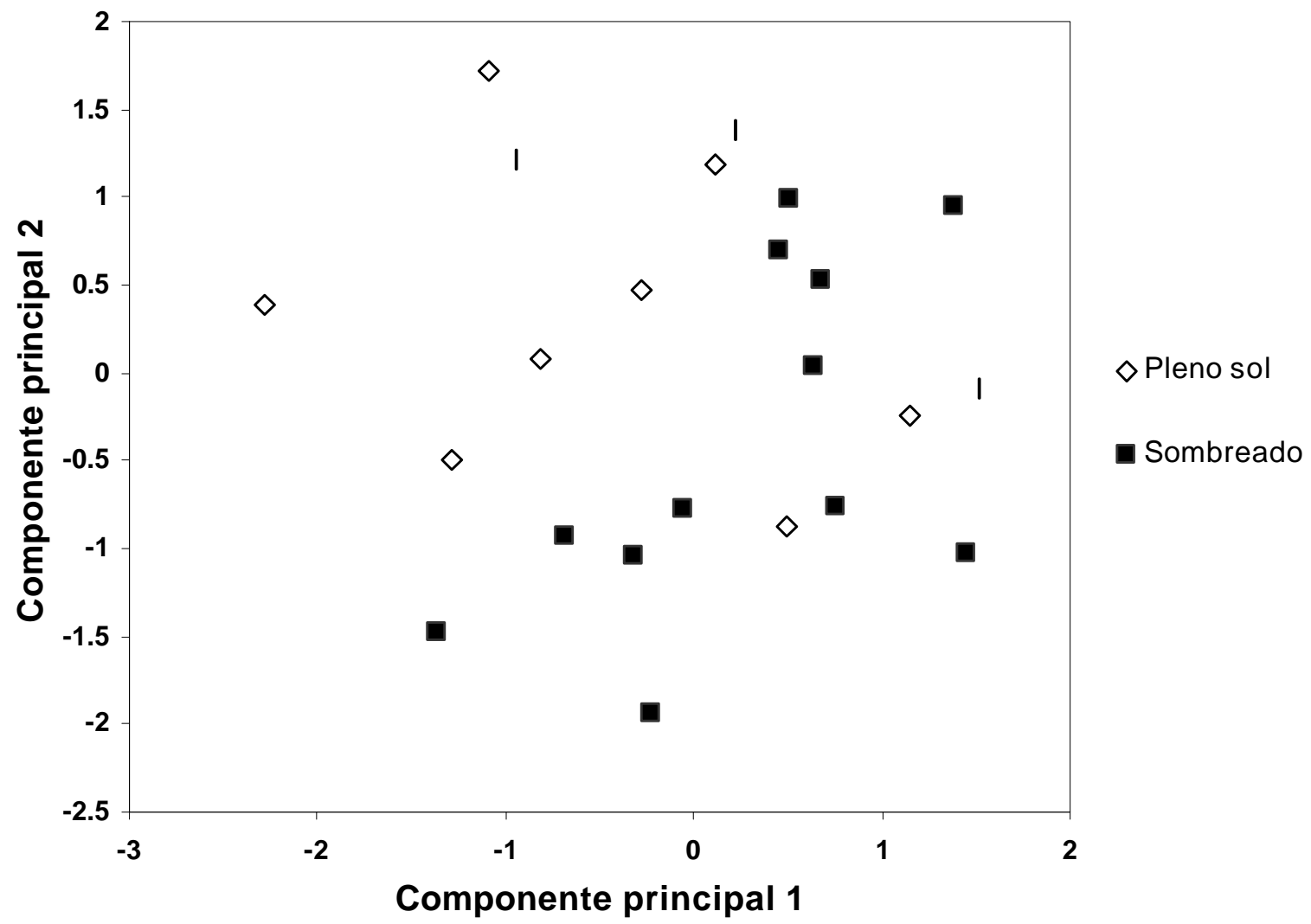

Figura 5 - Gráfico de dispersão com primeiro e segundo componentes principais (63\% da informação total) 


\subsubsection{Resultados da composição química elementar de folhas de café}

Foram determinadas as concentrações de $\mathrm{Br}, \mathrm{Ca}, \mathrm{Cs}, \mathrm{K}, \mathrm{Na}, \mathrm{Rb}$ e $\mathrm{Zn}$ nas folhas de cafeeiros provenientes dos dois sistemas de produção. As médias das concentrações elementares, respectivos desvios padrões e o teste de Tukey para comparações múltiplas entre médias, em nível de $95 \%$ de confiança, estão apresentados na Tabela 5. Os gráficos apresentando as médias dos sistemas de produção se encontram na Figura 6.

Houve diferença estatística significativa entre a concentração dos elementos Cs, K e $\mathrm{Rb}$ nas folhas dos cafeeiros nos sistemas a pleno sol e sombreado. Os elementos $\mathrm{K}$ e $\mathrm{Rb}$ apresentaram as maiores concentrações no sistema sombreado, enquanto, o Cs apresentou a maior concentração no sistema a pleno sol.

Os valores de concentração dos elementos nutricionais $\mathrm{Ca}, \mathrm{K}$ e $\mathrm{Zn}$ nas folhas dos cafeeiros estão dentro dos limites encontrados por diversos autores (Malavolta, 1986 e 1987; Matiello et al., 2002; Raij et al.,1991 e 1997.), sendo eles considerados adequados. Apenas para $\mathrm{K}$ nas folhas de cafeeiro do sistema a pleno sol, obteve-se um valor médio, enquanto o valor encontrado no sombreado é considerado alto.

A maior concentração de K nas folhas do sistema sombreado pode ser explicada pela discussão apresentada nos resultados de composição química elementar de grãos de cafés, item 4.3.1.

Comparando-se os resultados das folhas dos cafeeiros dos dois sistemas com valores obtidos por Markert (1998) para plantas, não se obtêm valores discrepantes. 
Tabela 5. Média das concentrações elementares e respectivos desvios padrões $\left(\mu \mathrm{g} \mathrm{g}^{-1}\right)$ de folhas de café nos dois tratamentos estudados

\begin{tabular}{|c|c|c|c|c|c|c|c|c|}
\hline \multicolumn{2}{|c|}{ Sombreado } & \multirow{2}{*}{$\begin{array}{c}\mathbf{B r} \\
2,9\end{array}$} & \multirow{2}{*}{$\begin{array}{c}\mathbf{C a} \\
12000\end{array}$} & \multirow{2}{*}{$\begin{array}{c}\text { Cs } \\
0,075\end{array}$} & \multirow{2}{*}{$\frac{\mathbf{K}}{29000}$} & \multirow{2}{*}{$\begin{array}{c}\mathbf{N a} \\
37\end{array}$} & \multirow{2}{*}{$\begin{array}{c}\mathbf{R b} \\
32\end{array}$} & \multirow{2}{*}{$\begin{array}{l}\mathbf{Z n} \\
12\end{array}$} \\
\hline Bloco I & Média & & & & & & & \\
\hline & Desvio Padrão & 1,1 & 1100 & 0,010 & 3000 & 11,1 & 6 & 1,0 \\
\hline \multirow[t]{2}{*}{ Bloco II } & Média & 2,8 & 10000 & 0,063 & 26000 & 32 & 30 & 11,1 \\
\hline & Desvio Padrão & 0,8 & 1700 & 0,010 & 4000 & 11,0 & 7 & 0,8 \\
\hline \multirow[t]{2}{*}{ Bloco III } & Média & 3,6 & 11000 & 0,070 & 29000 & 28 & 31,0 & 11,1 \\
\hline & Desvio Padrão & 1,2 & 1500 & 0,016 & 3000 & 5 & 5 & 0,2 \\
\hline \multirow{2}{*}{\multicolumn{2}{|c|}{$\begin{array}{l}\text { Média sombreado }(\mathrm{n}=12) \\
\text { Desvio padrão }\end{array}$}} & $3,1 \mathrm{a}$ & $11000 \mathrm{a}$ & $0,070 \mathrm{a}$ & $28000 \mathrm{a}$ & $32 \mathrm{a}$ & $31,0 \mathrm{a}$ & $11,4 \mathrm{a}$ \\
\hline & & 1,0 & 1600 & 0,012 & 3000 & 9 & 5 & 0,75 \\
\hline \multicolumn{9}{|l|}{ Pleno Sol } \\
\hline \multirow[t]{2}{*}{ Bloco I } & Média & 3,3 & 12000 & 0,091 & 20000 & 26 & 24 & 12 \\
\hline & Desvio Padrão & 0,7 & 3000 & 0,022 & 4000 & 9 & 5 & 3 \\
\hline \multirow[t]{2}{*}{ Bloco II } & Média & 4,4 & 9000 & 0,073 & 20000 & 24 & 20 & 10 \\
\hline & Desvio Pa & 0,5 & 1000 & 0,012 & 2000 & 6 & 2 & 1 \\
\hline \multirow[t]{2}{*}{ Bloco III } & Média & 3,4 & 9000 & 0,105 & 19000 & 36 & 21 & 10 \\
\hline & Desvio Padrão & 1,2 & 1000 & 0,042 & 6000 & 21,0 & 8 & 2 \\
\hline \multirow{2}{*}{\multicolumn{2}{|c|}{$\begin{array}{l}\text { Média pleno sol }(\mathrm{n}=12) \\
\text { Desvio padrão }\end{array}$}} & $3,7 \mathrm{a}$ & $10000 \mathrm{a}$ & $0,089 b$ & $20000 \mathrm{~b}$ & $29 a$ & $22 b$ & $11 \mathrm{a}$ \\
\hline & & 0,9 & 2000 & 0,029 & 4000 & 13 & 5 & 2 \\
\hline
\end{tabular}

Médias seguidas pela mesma letra não diferem estatisticamente entre si pelo teste de Tukey em nível de $95 \%$ de confiança 
$\mathrm{Br}$

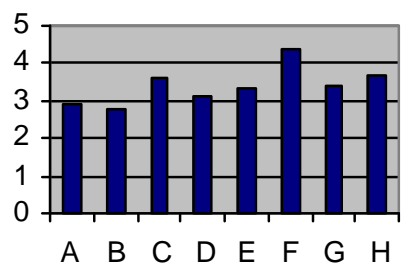

K

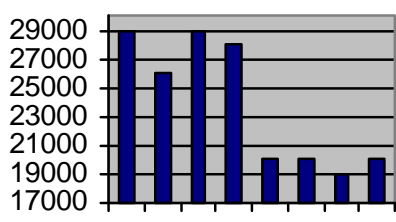

A B C D E F H
$\mathrm{Ca}$

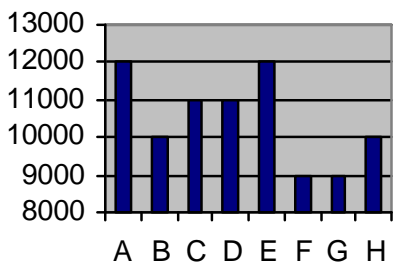

$\mathrm{Na}$

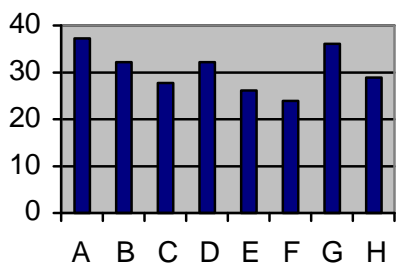

$\mathrm{Zn}$

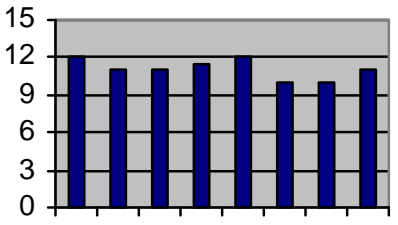

A B C D E F G H
Cs

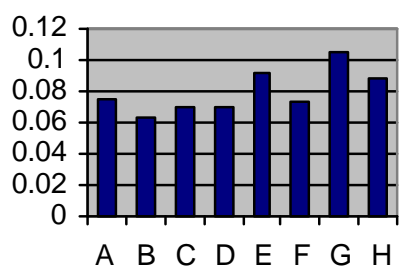

$\mathrm{Rb}$

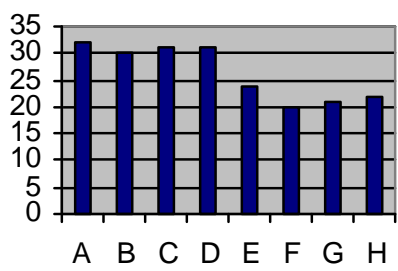

Figura 6 - Gráficos de composição química elementar $\left(\mu \mathrm{g} \mathrm{g}^{-1}\right)$ em folhas de café. A) Média das parcelas do bloco I do tratamento sombreado; B) Média das parcelas do bloco II do tratamento sombreado; C) Média das parcelas do bloco III do tratamento sombreado; D) Média geral das concentrações elementares das parcelas sombreadas; E) Média das parcelas do bloco I do tratamento a pleno sol; F) Média das parcelas do bloco II do tratamento a pleno sol; G) Média das parcelas do bloco III do tratamento a pleno sol; H) Média das concentrações elementares de todas as parcelas do tratamento a pleno sol

Foi aplicada a estatística multivariada análise dos componenetes principais (PCA) aos resultados de concentração obtidos por INAA de $\mathrm{Br}, \mathrm{Ca}, \mathrm{Cs}, \mathrm{K}, \mathrm{Na}, \mathrm{Rb}$ e $\mathrm{Zn}$ de folhas dos cafeeiros. Utilizou-se da concentração dos elementos $\mathrm{Br}, \mathrm{Ca}, \mathrm{Cs}, \mathrm{K}, \mathrm{Rb}$ e $\mathrm{Zn}$, que apresentaram maior contribuição no processo discriminatório. A Figura 7 apresenta o gráfico de dispersão com os dois primeiros componentes principais, que respondem, respectivamente, por $38 \%$ e $23 \%$ da informação total. Com exceção de três amostras de folhas dos cafeeiro a pleno sol (parcelas 6, 7 e 8) ou três amostras do sombreado (parcelas 1, 
11 e 20), nota-se uma separação entre as duas categorias. A amostra 6 apresentou altas concentrações de $\mathrm{Ca}$ e $\mathrm{K}$ distanciando-se das outras a pleno sol. As amostras 7 e 8 apresentaram concentrações de Ca mais altas que a média do pleno sol e similares ì do sistema sombreado, portanto localizando-se mais próximas a estas. A amostra 8 também apresentou concentração de Zn muito elevada (a maior de todas), o que pode ser a razão de seu isolamento. As amostras 1 e 20 apresentaram as maiores concentrações de $\mathrm{Br}$ e K, motivo de estarem ambas isoladas do grupo sombreado. A amostra 11 apresentou as menores concentrações de $\mathrm{Ca}$ e $\mathrm{K}$ do sistema sombreado, estando mais próxima dos valores encontrados a pleno sol. Os valores destas amostras podem ser vistos no Anexo G. Este resultado indica a possibilidade de discriminar sistemas de produção de café sob condições de pleno sol de cafés sombreados, baseando-se na análise química elementar de folhas de cafeeiros praticada em elevado nível metrológico.

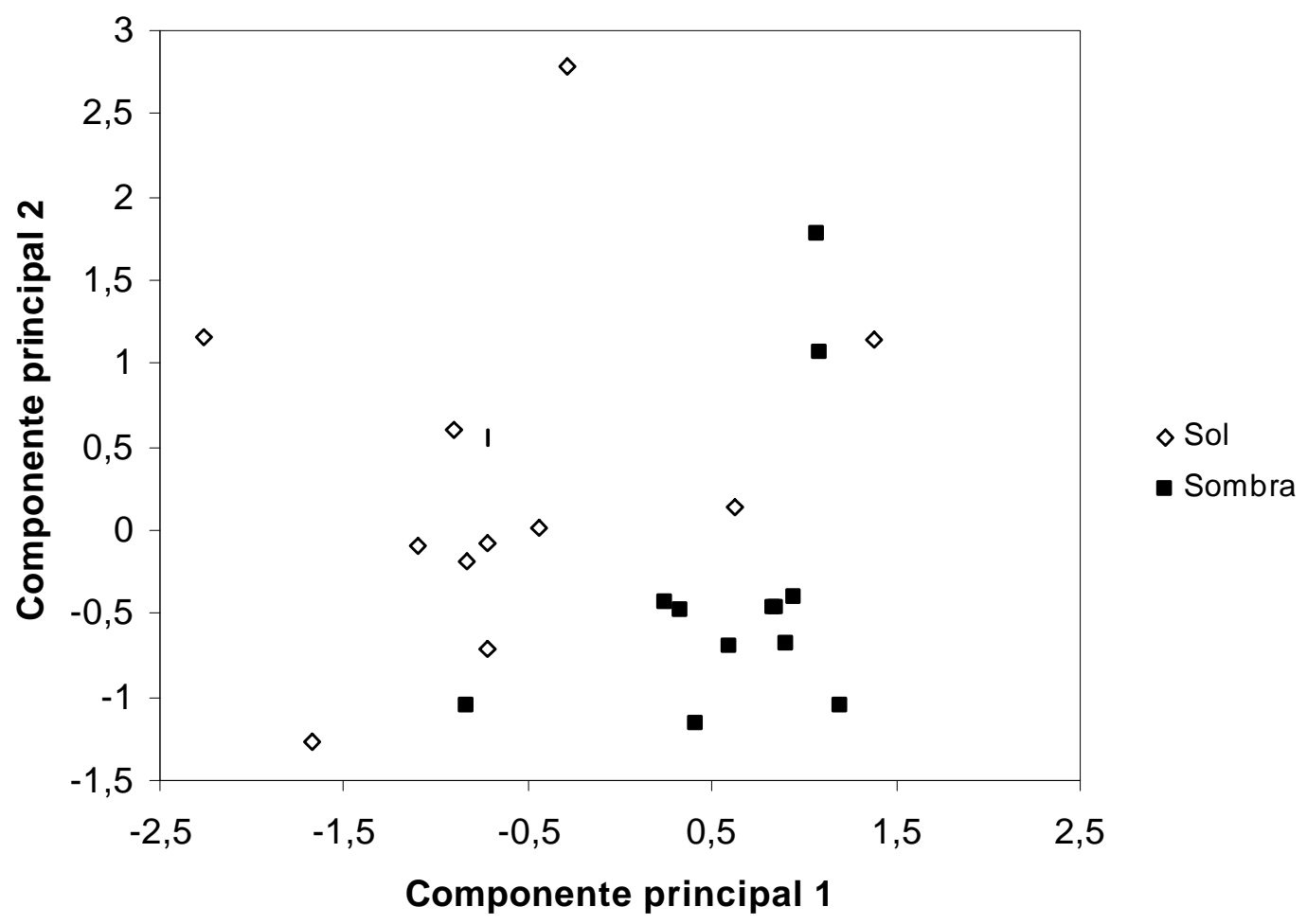

Figura 7 - Gráfico de dispersão com primeiro e segundo componentes principais (61\% da informação total) 


\subsubsection{Resultados da composição química elementar de folhas da espécie arbórea Platycyamus regnellii}

Tabela 6. Média e desvio padrão das concentrações elementares $\left(\mu \mathrm{g} \mathrm{g}^{-1}\right)$ de folhas da espécie arbórea

\begin{tabular}{lccccccc}
\hline & $\mathbf{B r}$ & $\mathbf{C a}$ & $\mathbf{C s}$ & $\mathbf{K}$ & $\mathbf{N a}$ & $\mathbf{R b}$ & $\mathbf{Z n}$ \\
\hline Média B I & 1,75 & 7130 & 0,117 & 16000 & 55,5 & 21,6 & 16,6 \\
DP B I & 0,0353 & 707 & 0,0127 & 919 & 9,54 & 0,353 & 0,8485 \\
Média B II & 6,45 & 6050 & 0,171 & 16100 & 62,5 & 21,7 & 15,4 \\
DP B II & 0,3747 & 516 & 0,01414 & 1909 & 10,39 & 3,04 & 0,6363 \\
Média B III & 1,35 & 14500 & 0,197 & 7730 & 59,1 & 12,5 & 12,0 \\
DP B III & 0,1272 & 565 & 0,01838 & 247 & 0,0707 & 0,49 & 1,2 \\
Média Folhas Árvore & 3,18 & 9230 & 0,162 & 13200 & 59,0 & 18,6 & 14,6 \\
DP Folhas Árvore & 2,5437 & 4141 & 0,03837 & 4378 & 7,0454 & 4,924 & 2,26 \\
\hline
\end{tabular}

As folhas da espécie arbórea Platycyamus regnellii apresentam quantidades consideráveis dos nutrientes $\mathrm{Ca}$, $\mathrm{K}$ e $\mathrm{Zn}$, e dos elementos $\mathrm{Br}$, Cs, $\mathrm{Na}$ e $\mathrm{Rb}$, sendo que estes provavelmente influenciaram na composição química elementar e na fertilidade do solo do sistema sombreado, conseqüentemente influenciando os outros parâmetros avaliados

\subsubsection{Resultados da composição química elementar de solo}

Foram determinadas as concentrações de $\mathrm{Br}, \mathrm{Ca}, \mathrm{Co}, \mathrm{Cs}, \mathrm{Fe}, \mathrm{Na}, \mathrm{Rb}, \mathrm{Sc}$ e $\mathrm{Zn}$ no solo dos dois sistemas de produção. As médias das concentrações elementares, seus respectivos desvios padrões e o teste de Tukey para comparações múltiplas entre médias, em nível de 95\% de confiança, encontram-se na Tabela 7. Os gráficos apresentando as composições químicas elementares médias dos sistemas se encontram na Figura 8.

Não houve diferença estatística significativa entre as amostras de solos procedentes dos sistemas a pleno sol e sombreado para todos os elementos avaliados.

Os valores obtidos através de INAA para os nutrientes $\mathrm{Ca}$, Fe e $\mathrm{Zn}$ no solo não podem ser comparados com os valores obtidos para os mesmos nutrientes por fertilidade, uma vez que a INAA avalia as quantidades totais dos elementos no solo, enquanto a fertilidade avalia apenas a quantidade disponível. 
Tabela 7. Média e desvio padrão das composições elementares $\left(\mu \mathrm{g}^{-1}\right)$ de solo nos dois tratamentos estudados

\begin{tabular}{|c|c|c|c|c|c|c|c|c|c|c|}
\hline \multicolumn{2}{|c|}{ Sombreado } & \multirow{2}{*}{$\begin{array}{l}\mathbf{B r} \\
8,4\end{array}$} & \multirow{2}{*}{$\begin{array}{c}\mathbf{C a} \\
50000\end{array}$} & \multirow{2}{*}{$\begin{array}{l}\text { Co } \\
4,2\end{array}$} & \multirow{2}{*}{$\begin{array}{l}\text { Cs } \\
1,3\end{array}$} & \multirow{2}{*}{$\begin{array}{c}\mathbf{F e} \\
45000\end{array}$} & \multirow{2}{*}{$\begin{array}{c}\mathbf{N a} \\
108\end{array}$} & \multirow{2}{*}{$\begin{array}{c}\mathbf{R b} \\
10\end{array}$} & \multirow{2}{*}{$\frac{\mathbf{S c}}{12}$} & \multirow{2}{*}{$\begin{array}{l}\mathbf{Z n} \\
60\end{array}$} \\
\hline Bloco I & Média & & & & & & & & & \\
\hline & Desvio Padrão & 0,8 & 7000 & 0,70 & 0,071 & 2000 & 41,7 & 12 & 1 & 5 \\
\hline \multirow[t]{2}{*}{ Bloco II } & Média & 11,5 & 40000 & 3,9 & 1,7 & 40000 & 95 & 23 & 11,5 & 53 \\
\hline & Desvio Padrão & 0,5 & 7000 & 0,015 & 0,11 & 800 & 6 & 1 & 0,5 & 3 \\
\hline \multirow[t]{2}{*}{ Bloco III } & Média & 12,4 & 60000 & 10,1 & 1,7 & 60000 & 91 & 8 & 17 & 76 \\
\hline & Desvio Padrão & 0,8 & 7000 & 8,9 & 0,11 & 3000 & 23 & 9 & 1 & 6 \\
\hline \multirow{2}{*}{\multicolumn{2}{|c|}{$\begin{array}{l}\text { Média sombreado }(\mathrm{n}=12) \\
\text { Desvio padrão }\end{array}$}} & $11,0 \mathrm{a}$ & $50000 \mathrm{a}$ & $6,1 \mathrm{a}$ & $1,5 \mathrm{a}$ & $48000 \mathrm{a}$ & $98 \mathrm{a}$ & $14 \mathrm{a}$ & $14 \mathrm{a}$ & $63 a$ \\
\hline & & 2 & 10000 & 5,5 & 0,2 & 9000 & 24 & 10 & 2 & 11 \\
\hline \multicolumn{11}{|l|}{ Pleno Sol } \\
\hline \multirow[t]{2}{*}{ Bloco I } & Média & 9 & 50000 & 4,2 & 1,3 & 52000 & 121 & 23 & 14 & 68 \\
\hline & Desvio Padrão & 1,2 & 7000 & 0,43 & 0,11 & 5000 & 25 & 4,2 & 2 & 10 \\
\hline \multirow[t]{2}{*}{ Bloco II } & Média & 11,4 & 40000 & 4,5 & 1,7 & 43000 & 93 & 22 & 13 & 55 \\
\hline & Desvio Padrão & 1,8 & 5000 & 0,81 & 0,13 & 4000 & 9 & 2 & 1 & 4 \\
\hline \multirow[t]{2}{*}{ Bloco III } & Média & 12,9 & 60000 & 6,1 & 1,7 & 57000 & 92 & 8 & 16 & 70 \\
\hline & Desvio Padrão & 3,9 & 4000 & 1,1 & 0,29 & 2000 & 1 & 10 & 1 & 6 \\
\hline \multirow{2}{*}{\multicolumn{2}{|c|}{$\begin{array}{l}\text { Média pleno sol }(\mathrm{n}=12) \\
\text { Desvio padrão }\end{array}$}} & $11,0 \mathrm{a}$ & $50000 \mathrm{a}$ & $4,9 \mathrm{a}$ & $1,6 \mathrm{a}$ & $51000 \mathrm{a}$ & $100 \mathrm{a}$ & $18 \mathrm{a}$ & $14 \mathrm{a}$ & $65 a$ \\
\hline & & 3 & 10000 & 1,1 & 0,2 & 7000 & 20 & 9 & 2 & 10 \\
\hline
\end{tabular}

Médias seguidas pela mesma letra não diferem estatisticamente entre si pelo teste de Tukey em nível de $95 \%$ de confiança 
$\mathrm{Br}$

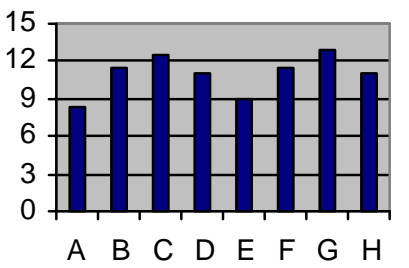

Cs

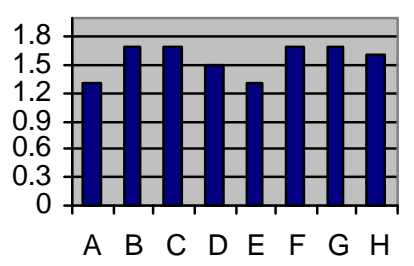

$\mathrm{Rb}$

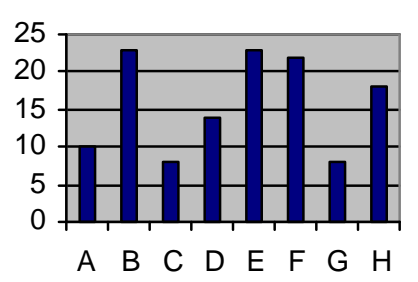

$\mathrm{Ca}$

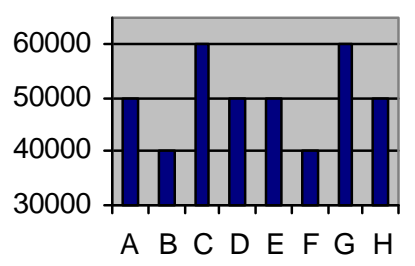

$\mathrm{Fe}$

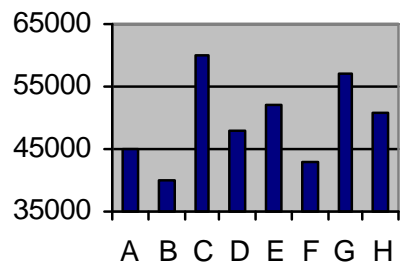

Sc

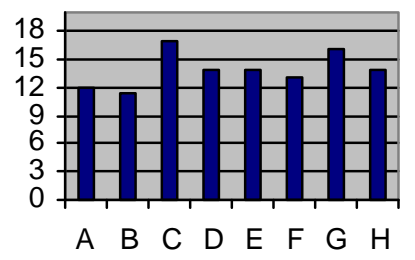

Co

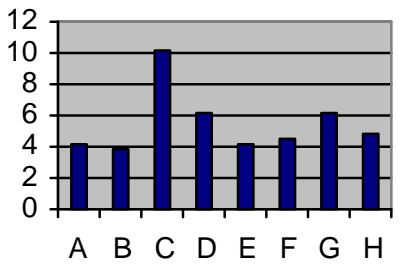

$\mathrm{Na}$

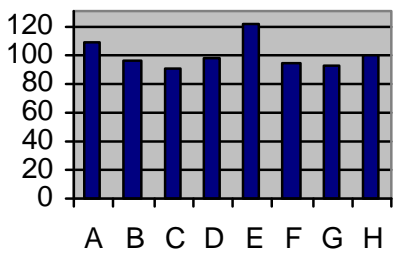

$\mathrm{Zn}$

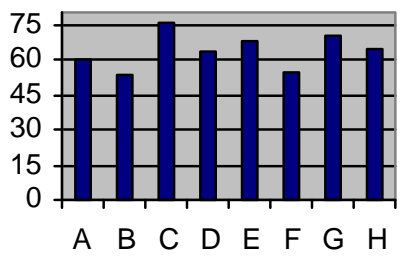

Figura 8 - Gráficos de composição química elementar $\left(\mu \mathrm{g} \mathrm{g}^{-1}\right)$ média do solo. A)Média das parcelas do bloco I do tratamento sombreado; B) Média das parcelas do bloco II do tratamento sombreado; C) Média das parcelas do bloco III do tratamento sombreado; D) Média geral das concentrações químicas elementares das parcelas do tratamento sombreado; E) Média das parcelas do bloco I do tratamento a pleno sol; F) Média das parcelas do bloco II do tratamento a pleno sol; G) Média das parcelas do bloco III do tratamento a pleno sol; H) Média geral das composições químicas elementares de todas as parcelas do tratamento a pleno sol

Foi aplicada a análise dos componenetes principais aos resultados de concentração obtidos por INAA de $\mathrm{Br}, \mathrm{Ca}, \mathrm{Co}, \mathrm{Cs}, \mathrm{Fe}, \mathrm{Na}, \mathrm{Rb}, \mathrm{Sc}$ e $\mathrm{Zn}$ de solos. Utilizou-se da concentração dos elementos $\mathrm{Br}, \mathrm{Ca}, \mathrm{Co}, \mathrm{Cs}, \mathrm{Fe}, \mathrm{Sc}$ e $\mathrm{Zn}$ que apresentaram maior contribuição no processo discriminatório. A Figura 9 apresenta o gráfico de dispersão com os dois primeiros componentes principais, que respondem, respectivamente, por $58 \%$ e $24 \%$ da informação total. Não foi possível discriminar os sistemas de produção de café sob condições de pleno sol de cafés sombreados, baseando-se na análise química elementar dos 
solos. Foi possível distinguir os 3 blocos do experimento, uma vez que as 4 repetições de cada bloco do sistema sombreado encontram-se bem agrupadas. As repetições dos blocos a pleno sol também se agrupam, embora menos que as do sombreado.

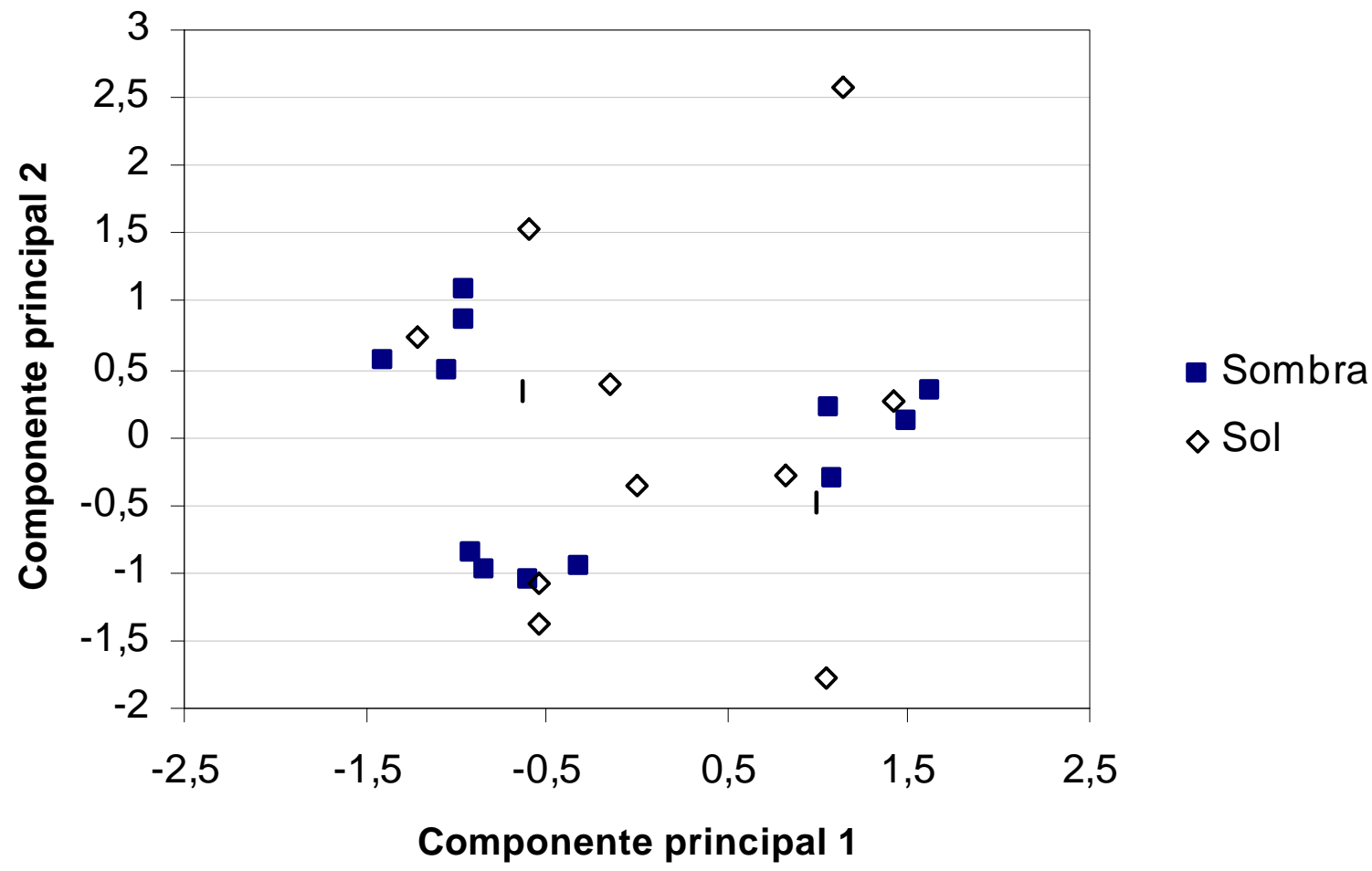

Figura 9 - Gráfico de dispersão com primeiro e segundo componentes principais ( $82 \%$ da informação total) 


\subsection{Resultados de fertilidade, pH e matéria orgânica do solo}

Foram determinados os valores de $\mathrm{P}, \mathrm{Ca}, \mathrm{Mg}, \mathrm{K}, \mathrm{Al}+\mathrm{H}, \mathrm{Cu}, \mathrm{Fe}, \mathrm{Mn}$ e $\mathrm{Zn}$, bem como pH e matéria orgânica no solo proveniente dos dois sistemas. As médias de fertilidade do solo, respectivos desvios padrões e o teste de Tukey para comparações múltiplas entre médias, em nível de $95 \%$ de confiança, estão na Tabela 8. Os gráficos apresentando os valores das médias de composição elementar dos sistemas se encontram na Figura 10.

Tabela 8. Média e desvio padrão de fertilidade do solo nos dois tratamentos estudados

\begin{tabular}{|c|c|c|c|c|c|c|c|c|c|c|c|}
\hline & $\mathrm{CaCl} 2$ & $\mathbf{P}$ & MO & $\mathbf{C a}$ & Mg & $\mathbf{K}$ & $\mathbf{A l}+\mathbf{H}$ & $\mathrm{Cu}$ & $\mathbf{F e}$ & Mn & Zn \\
\hline & $\mathrm{pH}$ & $\mathrm{dm}^{-3}$ & $\begin{array}{c}\mathrm{mmol} \\
\mathrm{dm}^{-3}\end{array}$ & $\begin{array}{c}\mathrm{mmol} \\
\mathrm{dm}^{-3}\end{array}$ & $\begin{array}{c}\mathrm{mmol} \\
\mathrm{dm}^{-3}\end{array}$ & $\begin{array}{l}\mathrm{mmol} \\
\mathrm{dm}^{-3}\end{array}$ & $\begin{array}{l}\mathrm{mmol} \\
\mathrm{dm}^{-3}\end{array}$ & $\begin{array}{c}\mathrm{mg} \mathrm{kg}^{-} \\
1\end{array}$ & $\begin{array}{c}\mathrm{mg} \mathrm{kg}^{-} \\
1\end{array}$ & $\begin{array}{c}\mathrm{mg} \mathrm{kg}^{-} \\
1\end{array}$ & $\begin{array}{c}\mathrm{mg} \\
\mathrm{kg}^{-1} 1\end{array}$ \\
\hline \multicolumn{12}{|l|}{ Sombreado } \\
\hline Média Bloco I & 6,24 & 15,2 & 24,3 & 71,4 & 29,0 & 2,99 & 18,9 & 3,95 & 39,5 & 7,63 & 4,85 \\
\hline DP Bloco I & 0,518 & 5,553 & 5,67 & 18,46 & 7,85 & 0,43 & 6,497 & 1,441 & 14,78 & 1,97 & 1,487 \\
\hline Média Bloco II & 5,52 & 11,9 & 24,7 & 57,4 & 27,9 & 3,14 & 32,1 & 2,94 & 81,7 & 5,17 & 2,71 \\
\hline DP Bloco II & 0,473 & 8,09 & 0,814 & 17,11 & 11,02 & 1,10 & 9,036 & 0,2286 & 20,52 & 0,4282 & 0,11 \\
\hline Média Bloco III & 5,34 & 14,1 & 26,4 & 69,1 & 23,4 & 3,07 & 39,5 & 6,09 & 81,1 & 5,53 & 5,83 \\
\hline DP Bloco III & 0,543 & 5,47 & 3,121 & 27,582 & 6,15 & 0,6319 & 15,08 & 1,5847 & 20,02 & 1,976 & 2,30 \\
\hline $\begin{array}{l}\text { Média Geral } \\
\text { Sombreado }\end{array}$ & $5,70 \mathrm{a}$ & $13,7 \mathrm{a}$ & $25,1 \mathrm{a}$ & $66,0 \mathrm{a}$ & $26,7 \mathrm{a}$ & $3,06 \mathrm{a}$ & $30,2 \mathrm{a}$ & $4,33 \mathrm{a}$ & $67,4 \mathrm{a}$ & $6,11 \mathrm{a}$ & $4,46 a$ \\
\hline $\begin{array}{l}\text { DP Geral } \\
\text { Sombreado }\end{array}$ & 0,6153 & 6,032 & 3,544 & 20,524 & 8,165 & 0,70 & 13,226 & 1,776 & 26,63 & 1,86 & 1,976 \\
\hline & & & & & & & & & & & \\
\hline Média Bloco I & 6,40 & 11,8 & 21,7 & 78,0 & 35,8 & 1,85 & 17,6 & 4,24 & 33,8 & 5,78 & 4,84 \\
\hline DP Bloco I & 0,432 & 1,715 & 1,6 & 15,74 & 7,189 & 1,07 & 6,60 & 2,4 & 12,08 & 0,893 & 2,476 \\
\hline Média Bloco II & 5,49 & 8,46 & 23,3 & 64,5 & 29,8 & 1,58 & 33,7 & 3,46 & 76,9 & 4,98 & 2,86 \\
\hline DP Bloco II & 0,017 & 1,11 & 1,41 & 3,45 & 5,679 & 0,407 & 1,926 & 1,30 & 10,367 & 2,48 & 0,919 \\
\hline Média Bloco III & 5,63 & 8,13 & 26,8 & 69,4 & 32,3 & 1,16 & 39,1 & 4,78 & 77,7 & 3,68 & 4,01 \\
\hline DP Bloco III & 0,397 & 2,8 & 5,394 & 12,059 & 4,642 & 0,164 & 13,08 & 1,791 & 41,11 & 1,2877 & 0,88 \\
\hline $\begin{array}{l}\text { Média Geral } \\
\text { Pleno Sol }\end{array}$ & $5,84 a$ & $9,45 b$ & $23,9 a$ & $70,6 a$ & $32,6 a$ & $1,53 b$ & $30,1 \mathrm{a}$ & $4,16 a$ & $62,8 \mathrm{a}$ & $4,81 \mathrm{a}$ & $3.90 \mathrm{a}$ \\
\hline $\begin{array}{l}\text { DP Geral Pleno } \\
\text { Sol }\end{array}$ & 0,5175 & 2,495 & 3,755 & 12,016 & 5,96 & 0,674 & 12,266 & 1,80 & 31,454 & 1,78 & 1,684 \\
\hline
\end{tabular}

Médias seguidas pela mesma letra não diferem estatisticamente entre si pelo teste de Tukey em nível de $95 \%$ de confiança 
$\mathrm{pH}$

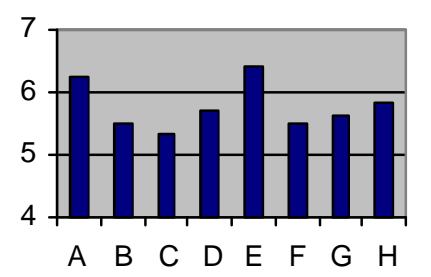

$\mathrm{Ca}$

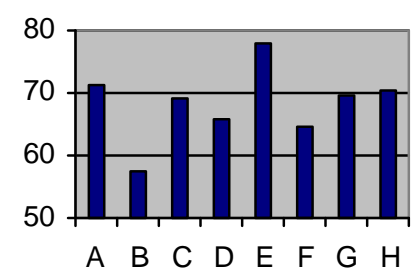

$\mathrm{Al}+\mathrm{H}$

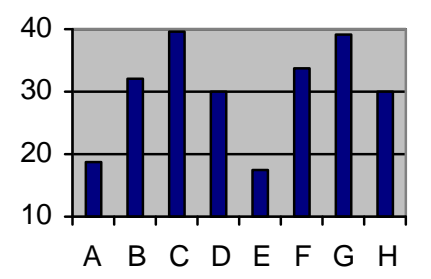

$\mathrm{P}$

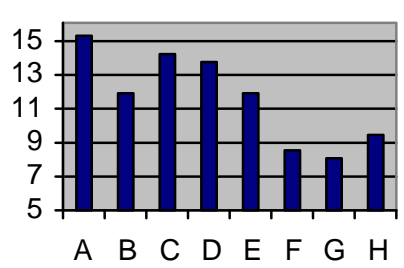

$\mathrm{Mg}$

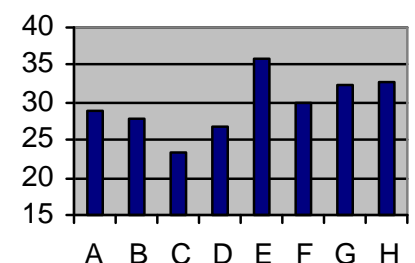

$\mathrm{Cu}$

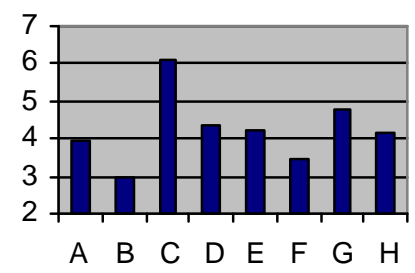

MO

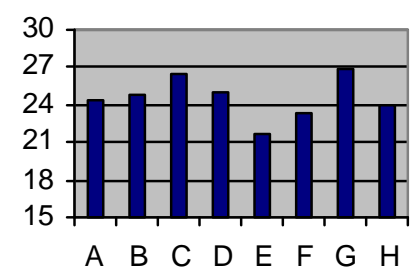

K

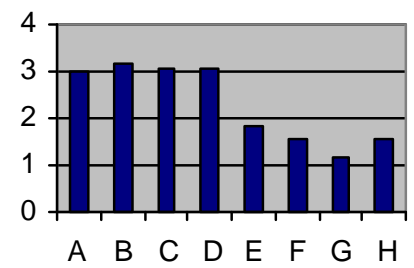

$\mathrm{Fe}$

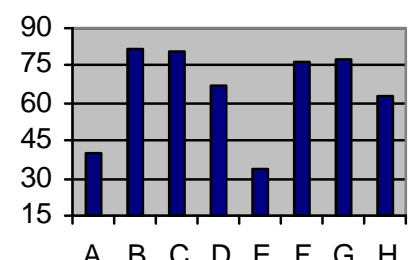

$\mathrm{Mn}$
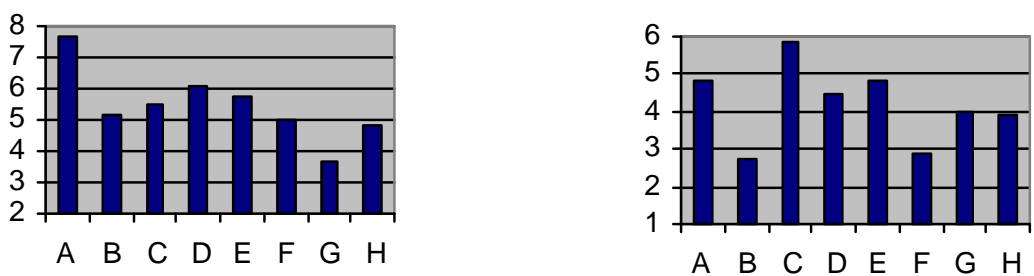

Figura 10 - Gráficos de Fertilidade: $\mathrm{P}\left(\mathrm{mg} \mathrm{dm}^{-3}\right), \mathrm{Ca}, \mathrm{Mg}, \mathrm{K} \mathrm{e} \mathrm{Al}+\mathrm{H}\left(\mathrm{mmol} \mathrm{dm}^{-3}\right), \mathrm{Cu}, \mathrm{Fe}$, Mn e $\mathrm{Zn}\left(\mathrm{mg} \mathrm{kg}^{-1}\right), \mathrm{pH}\left(\mathrm{CaCl}_{2}\right)$ e matéria orgânica do solo $\left(\mathrm{mmol} \mathrm{dm}^{-3}\right)$. A) Média das parcelas do bloco I do tratamento sombreado; B) Média das parcelas do bloco II do tratamento sombreado; C) Média das parcelas do bloco III do tratamento sombreado; D) Média geral das parcelas do tratamento sombreado; E) Média das parcelas do bloco I do tratamento a pleno sol; F) Média das parcelas do bloco II do tratamento a pleno sol; G) Média das parcelas do bloco III do tratamento a pleno sol; H) Média geral das parcelas do tratamento a pleno sol 
Os valores no solo obtidos para os nutrientes $\mathrm{Ca}, \mathrm{Mg}, \mathrm{Cu}, \mathrm{Fe}, \mathrm{Mn}$ e $\mathrm{Zn}$ se encontram dentro dos limites apontados por diversos autores (Malavolta, 1986 e 1987; Matiello et al., 2002; Raij et al.,1991 e 1997.) sendo que estes são considerados como altos, com exceção do Mn, considerado como médio.

Os valores obtidos para pH e matéria orgânica do solo também se encontram dentro dos limites estabelecidos pelos mesmos autores, considerados respectivamente como adequados alto e médio.

Houve diferença estatística significativa entre os valores no solo dos dois sistemas avaliados para os elementos $\mathrm{P}$ e $\mathrm{K}$, sendo que para ambos elementos, os maiores valores foram encontrados no sistema sombreado.

Os valores para $\mathrm{P}$ se encontram dentro dos limites apontados por diversos autores (Malavolta, 1986 e 1987; Matiello et al., 2002; Raij et al.,1991 e 1997.). Entretanto, o valor obtido para o P no sistema sombreado é considerado médio, e para o sistema a pleno sol é considerado baixo.

Os valores de P orgânico do solo estão relacionados com a quantidade de matéria orgânica (Brady, 1989; Raij., 1991). Foi observado por Fernandes et al. (1997) maior quantidade de $\mathrm{P}$ nas camadas superficiais do solo, relacionados com maior concentração de matéria orgânica. Os valores de matéria orgânica no solo são similares para os dois sistemas, e portanto não podem ser considerados para explicar a diferença na concentração de $P$ encontrada entre os dois sistemas.

$\mathrm{O}$ pH do solo também pode interferir na disponibilidade de $\mathrm{P}$ na solução do solo (Primavesi, 1990). Contudo também não houve diferença significativa para pH entre os dois sistemas, não sendo eficiente para explicar a diferença de valor de $\mathrm{P}$ no solo dos dois sistemas.

Apesar de ser pouco móvel no solo, o P quando na solução do solo pode, embora dificilmente, ser lixiviado por chuvas muito intensas. Estas chuvas ocasionam também erosão laminar de solo, que é a maior causa de perda de P do solo (Mills \& Jones, 1997).

No sistema sombreado, a possível perda do P por lixiviação e por erosão laminar pode ter sido reduzida. As árvores minimizam a lixiviação (Clarke \& Macrae, 1985b; Fernandes, 1986) pela presença de suas raízes, que ocupam um grande volume de solo, retendo e absorvendo o P da solução do solo que poderia ser perdido (Jordan, 1985; Pritchett 
\& Fisher, 1985). Já a perda de $\mathrm{P}$ por erosão laminar pode ter sido reduzida no sistema sombreado pela maior presença de folhas da espécie arbórea na superfície do solo (Fernandes, 1986; Theodoro, 2001), que são um obstáculo físico, reduzindo o escorrimento superficial e estimulando a infiltração. A menor erosão laminar também pode ser decorrente de uma maior infiltração e absorção de água no solo, conseqüência de um solo mais aerado, observada em cafezais sombreados (Clarke \& Macrae, 1985b; Fernandes, 1986).

Em pesquisa comparativa entre área de produção de café e mata nativa, Cunha (1995) diagnosticou que a quantidade de P no solo foi afetada pela inclinação do relevo. Concluiu que em áreas de café mais íngremes ocorreu maior perda de $\mathrm{P}$, enquanto na mata a perda de $\mathrm{P}$ foi mínima tanto na parte mais alta quanto na parte mais baixa, já que a vegetação impede seu transporte no sentido da declividade via erosão.

Além desta possível redução de lixiviação e erosão laminar, no sistema sombreado pode ocorrer também a liberação de exudatos pelas raízes da espécie arbórea, bem como a reciclagem dos nutrientes pela deposição das folhas da árvore no solo.

Em estudo realizado por Tornquist et al. (1999) comparando sistemas agroflorestais com pastagens na Costa Rica, foram encontrados valores mais altos de $\mathrm{P}$ extraível na profundidade de $0-25 \mathrm{~cm}$ no primeiro caso. Estes valores podem estar relacionados com os exudatos liberados pelas raízes das árvores (em sua maioria ácidos orgânicos), os quais ajudariam na disponibilização do P (Fisher, 1995) e também com a absorção de P de um maior volume de solo pelas raízes das árvores, seguido do retorno do elemento àsuperfície do solo através da queda das folhas destas árvores (Harcombe, 1980). As folhas que caem no solo contêm uma grande proporção dos nutrientes extraídos anualmente pelas árvores do solo, o que pode ser visualizado nas Tabelas 8, 12 e 13. Esta vegetação morta no solo se decompõe, liberando minerais, como o P, para as plantas reutilizarem (Cunha, 1995; Jordan, 1985; Pritchett \& Fisher, 1985; Theodoro, 2001).

Os valores para $\mathrm{K}$ estão dentro dos limites estabelecidos por diversos autores (Malavolta, 1986 e 1987; Matiello et al., 2002; Raij et al.,1991 e 1997.). O valor obtido para o K no sistema sombreado é considerado como valor alto e o valor para o sistema a pleno sol como valor médio. Este resultado pode ser explicado pelo comportamento do K no solo e pela reciclagem deste elemento. 
Por ser um elemento muito móvel no solo, principalmente quando o solo está úmido (Mills \& Jones, 1997; Raij, 1991), o K é muito propenso a ser perdido por lixiviação. Pode também ser perdido por erosão laminar, similarmente ao $\mathrm{P}$, embora a tendência é que a maior parte do K seja infiltrado no solo e perdido por lixiviação.

A lixiviação de nutrientes com cargas positivas (cátions), como $\mathrm{K}^{+}$, é freqüente em solos tropicais úmidos. Neste solos, os cátions são substituídos por íons $\mathrm{H}^{+}$, resultantes da respiração do solo e da decomposição da matéria orgânica. Os cátions formam novos produtos e se perdem pelo perfil do solo (Jordan, 1985). A presença de árvores pode minimizar a lixiviação (Clarke \& Macrae, 1985b.; Fernandes, 1986).

Experimento relatado por Pritchett \& Fisher (1985) avaliou perdas de nutrientes pela água em florestas intactas, através de método com lisímetro e enquanto $10,1 \mathrm{~kg} / \mathrm{ha} / \mathrm{ano}$ lixiviaram da superfície do solo para os $3 \mathrm{~cm}$ superiores de solo mineral, apenas 1,0 $\mathrm{kg} / \mathrm{ha} /$ ano lixiviou além da zona de abrangência das raízes. Este resultado pode ser explicado pela presença das raízes das espécies arbóreas, as quais ocupam grande volume de solo, retendo e absorvendo o K que poderia ser perdido (Jordan, 1985; Pritchett \& Fisher, 1985).

Além desta possível redução de lixiviação e erosão laminar, no sistema sombreado conta-se também com a reciclagem dos nutrientes pela deposição das folhas da espécie arbórea no solo. As folhas que caem no solo contêm uma grande proporção dos nutrientes extraídos anualmente pelas árvores do solo, o que pode ser visualizado nas Tabelas 8, 12 e 13. Esta vegetação depositada no solo se decompõe, liberando minerais como o K para as plantas reutilizarem (Jordan, 1985; Pritchett \& Fisher, 1985; Theodoro, 2001). O K, por não participar de combinações orgânicas na planta, como N, P e S, é liberado rapidamente ao solo, quando os restos vegetais são a ele adicionados (Kiehl, 1985).

\subsection{Resultados de análise foliar de café}

Foram determinadas as concentrações de N, P, K, Ca, Mg, S, Cu, Fe, Mn e Zn nas folhas de cafeeiros provenientes dos dois sistemas. As médias das concentrações foliares, respectivos desvios padrões e o teste de Tukey para comparações múltiplas entre médias, em nível de 95\% de confiança, se encontram na Tabela 9. Os gráficos apresentando as concentrações médias nas folhas de cafeeiros dos dois sistemas estão na Figura 11. 
Tabela 9. Média das concentrações foliares de café e desvio padrão nos dois tratamentos estudados

\begin{tabular}{|c|c|c|c|c|c|c|c|c|c|c|}
\hline & $\mathbf{N}$ & $\mathbf{P}$ & K & $\overline{\mathbf{C a}}$ & Mg & $\mathbf{S}$ & $\mathbf{C u}$ & $\mathbf{F e}$ & Mn & $\mathbf{Z n}$ \\
\hline & $\mathrm{g} / \mathrm{kg}$ & $\mathrm{G} / \mathrm{kg}$ & $\mathrm{g} / \mathrm{kg}$ & $\mathrm{g} / \mathrm{kg}$ & $\mathrm{g} / \mathrm{kg}$ & $\mathrm{g} / \mathrm{kg}$ & $\mathrm{mg} / \mathrm{kg}$ & $\mathrm{mg} / \mathrm{kg}$ & $\mathrm{mg} / \mathrm{kg}$ & $\mathrm{mg} / \mathrm{kg}$ \\
\hline \multicolumn{11}{|l|}{ Sombreado } \\
\hline Média Bloco I & 27,4 & 1,79 & 30,3 & 16,7 & 6,74 & 1,89 & 11,2 & 126,0 & 43,2 & 16,6 \\
\hline DP Bloco I & 0,938 & 0,104 & 1,4868 & 3,418 & 0,5288 & 0,1239 & 0,888 & 12,88 & 2,872 & 3,886 \\
\hline Média Bloco II & 28,3 & 1,71 & 31,0 & 12,2 & 5,65 & 1,96 & 12,7 & 131,0 & 51,2 & 14,5 \\
\hline DP Bloco II & 0,9102 & 0,20 & 2,0457 & 1,035 & 0,3872 & 0,0623 & 1,2535 & 4,89 & 5,84 & 6,11 \\
\hline Média Bloco III & 26,4 & 1,60 & 33,4 & 14,9 & 5,96 & 1,93 & 10,6 & 112,0 & 49,9 & 17,3 \\
\hline DP Bloco III & 0,7487 & 0,0768 & 3,0772 & 2,109 & 0,6723 & 0,1871 & 2,138 & 16,764 & 4,73 & 10,28 \\
\hline Média & $27,3 \mathrm{a}$ & $1,70 \mathrm{a}$ & $31,6 a$ & $14,6 \mathrm{a}$ & $6,12 \mathrm{a}$ & $1,93 \mathrm{a}$ & $11,5 \mathrm{a}$ & $123,0 \mathrm{a}$ & $48,1 \mathrm{a}$ & $16,1 \mathrm{a}$ \\
\hline \multicolumn{11}{|l|}{ Sombreado } \\
\hline Geral & 1,135 & 0,1507 & 2,504 & 2,898 & 0,6856 & 0,1258 & 1,6577 & 14,088 & 5,577 & 6,691 \\
\hline \multirow{2}{*}{\multicolumn{11}{|c|}{ Pleno Sol }} \\
\hline & & & & & & & & & & \\
\hline Média Bloco I & 28,0 & 1,83 & 25,5 & 13,5 & 6,23 & 1,96 & 16,6 & 109,0 & 40,0 & 15,8 \\
\hline DP Bloco I & 1,22 & 0,147 & 2,025 & 2,358 & 0,9787 & 0,1948 & 3,644 & 24,87 & 2,209 & 10,756 \\
\hline Média Bloco II & 27,4 & 1,66 & 25,0 & 11,0 & 5,68 & 2,06 & 16,0 & 99,6 & 56,2 & 17,4 \\
\hline DP Bloco II & 0,608 & 0,0567 & 1,537 & 1,598 & 0,7847 & 0,5245 & 3,038 & 15,27 & 25,26 & 11,858 \\
\hline Média Bloco III & 26,5 & 1,50 & 25,4 & 13,1 & 6,29 & 1,92 & 14,4 & 140,0 & 46,8 & 19,1 \\
\hline DP Bloco III & 2,0636 & 0,0457 & 6,709 & 2,6633 & 0,8056 & 0,3169 & 2,2144 & 33,02 & 13,43 & 9,17 \\
\hline $\begin{array}{l}\text { Média Geral } \\
\text { Pleno Sol }\end{array}$ & $27,3 \mathrm{a}$ & $1,66 \mathrm{a}$ & $25,3 \mathrm{~b}$ & $12,5 \mathrm{~b}$ & $6,07 \mathrm{a}$ & $1,98 \mathrm{a}$ & $15,7 \mathrm{~b}$ & $116,0 \mathrm{a}$ & $47,7 \mathrm{a}$ & $17,4 \mathrm{a}$ \\
\hline $\begin{array}{l}\text { DP Geral Pleno } \\
\text { Sol }\end{array}$ & 1,45 & 0,164 & 3,755 & 2,3363 & 0,8295 & 0,342 & 2,9023 & 29,223 & 16,50 & 9,721 \\
\hline
\end{tabular}

Médias seguidas pela mesma letra não diferem estatisticamente entre si pelo teste de Tukey em nível de $95 \%$ de confiança

Os valores obtidos nas folhas para os elementos N, P, Mg, S, Fe, Mn e Zn estão dentro dos limites encontrados por diversos autores (Malavolta, 1986 e 1987; Matiello et al., 2002; Raij et al.,1991 e 1997), sendo considerados valores altos com exceção do N (considerado médio).

Houve diferença significativa entre as concentrações foliares de $\mathrm{K}$, $\mathrm{Ca}$ e $\mathrm{Cu}$ dos dois sistemas, sendo $\mathrm{K}$ e Ca maiores no sistema sombreado, e Cu maior no sistema a pleno sol.Os valores para estes elementos também se enquadram nos limites observados por diversos autores (Malavolta, 1986 e 1987; Matiello et al., 2002; Raij et al.,1991 e 1997), sendo considerados altos.

A maior concentração de K nas folhas do sistema sombreado pode ser explicada pela discussão apresentada nos resultados de composição química elementar de grãos de cafés, item 4.3.1. 
Já a maior concentração de Ca nas folhas de cafeeiros do sistema sombreado pode ser atribuída à maior quantidade de raízes do cafeeiro, que irá ocupar maior volume de solo e, conseqüentemente, absorver mais nutrientes. A maior quantidade de raízes do cafeeiro ocorre em sistemas de café sombreado, como resultado de uma menor temperatura do solo (Rena \& Maestri, 1986). Isto vale para o K também, sendo mais um fator para encontrar maior concentração de $\mathrm{K}$ nas folhas do sistema sombreado.

A maior concentração de $\mathrm{Cu}$ observada nas folhas do sistema a pleno sol pode ser devido a sua baixa mobilidade na planta (Mills \& Jones, 1997), que se move complexado a compostos solúveis de nitrogênio, como aminoácidos livres. Esta maior concentração de $\mathrm{Cu}$ nas folhas do sistema a pleno sol pode, portanto, estar ligada à maior concentração de aminoácidos livres. Trabalho de Souza (2001) indica que plantas de café a pleno sol possuem maior concentração de aminoácidos livres que plantas de café sombreadas. Este resultado indica que plantas de café a pleno sol, por apresentarem maiores concentrações de aminoácidos livres, estariam mais propícias ao ataque de pragas e doenças, de acordo com a teoria da trofobiose (Chaboussou, 1987). 
$\mathrm{N}$

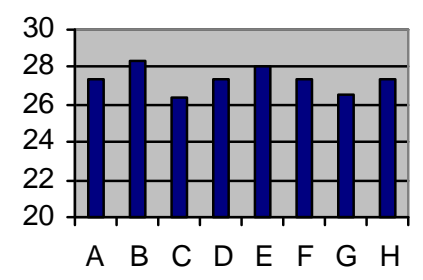

$\mathrm{Ca}$

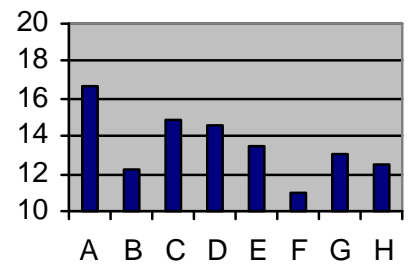

$\mathrm{Cu}$

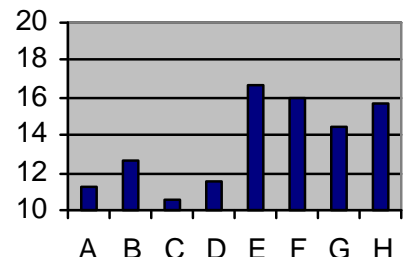

$\mathrm{P}$

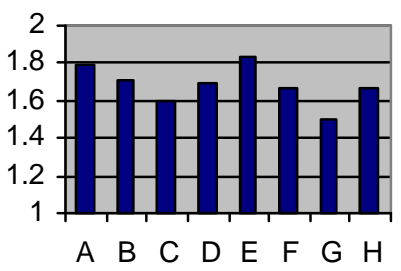

$\mathrm{Mg}$

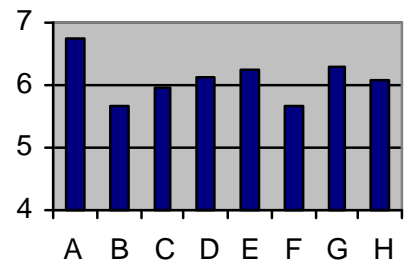

$\mathrm{Fe}$
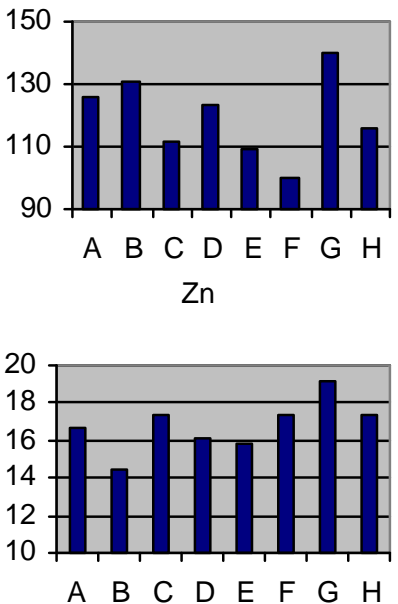

$\mathrm{K}$

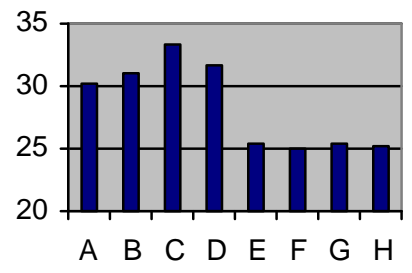

S

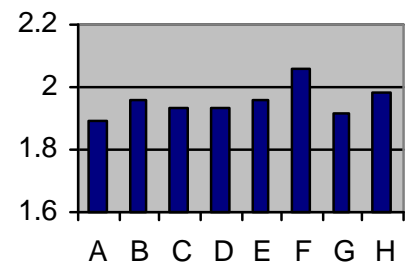

$\mathrm{Mn}$

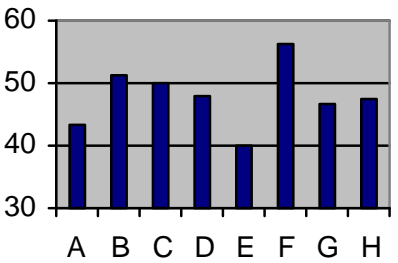

Figura 11 - Gráficos de análise foliar de café: N, P, K, Ca, Mg, S (g/kg), Cu, Fe, Mn e Zn $(\mathrm{mg} / \mathrm{kg})$. A) Média das parcelas do bloco I do tratamento sombreado; B) Média das parcelas do bloco II do tratamento sombreado; C) Média das parcelas do bloco III do tratamento sombreado; D) Média geral das parcelas do tratamento sombreado; E) Média das parcelas do bloco I do tratamento a pleno sol; F) Média das parcelas do bloco II do tratamento a pleno sol; G) Média das parcelas do bloco III do tratamento a pleno sol; H) Média geral das parcelas do tratamento a pleno sol 
Tabela 10.Comparação entre INAA, espectrometria de absorção atômica (1) e fotometria por emissão de chama (2) para determinação dos nutrientes $\mathrm{Ca}, \mathrm{K}$ e Zn em folhas de cafeeiro

\begin{tabular}{|c|c|c|c|c|c|c|}
\hline \multicolumn{7}{|c|}{ Sombreado } \\
\hline & \multicolumn{2}{|c|}{ INAA $\left(\mu \mathrm{g} \mathrm{g}^{-1}\right)$} & & $1(\mathrm{mg} / \mathrm{kg})$ & $2(\mathrm{mg} / \mathrm{kg})$ & $1(\mathrm{mg} / \mathrm{kg})$ \\
\hline & $\mathrm{Ca}$ & $\mathrm{K}$ & $\mathrm{Zn}$ & $\mathrm{Ca}$ & $\mathrm{K}$ & $\mathrm{Zn}$ \\
\hline Bloco I & 12000 & 29000 & 12 & 16700 & 30300 & 16,6 \\
\hline Bloco II & 10000 & 26000 & 11,1 & 12200 & 31000 & 14,5 \\
\hline Bloco III & 11000 & 29000 & 11,1 & 14900 & 33400 & 17,3 \\
\hline \multirow{4}{*}{$\begin{array}{l}\text { Média } \\
\text { sombreado }\end{array}$} & $11000 \mathrm{a}$ & $28000 \mathrm{a}$ & $11,4 \mathrm{a}$ & $14600 \mathrm{a}$ & $31,6^{\mathrm{a}}$ & $16,1 \mathrm{a}$ \\
\hline & \multirow{2}{*}{\multicolumn{2}{|c|}{ INAA $\left(\mu g g^{-1}\right)$}} & no so & & & \\
\hline & & & & $1(\mathrm{mg} / \mathrm{kg})$ & $2(\mathrm{mg} / \mathrm{kg})$ & $1(\mathrm{mg} / \mathrm{kg})$ \\
\hline & $\mathrm{Ca}$ & K & $\mathrm{Zn}$ & $\mathrm{Ca}$ & K & $\mathrm{Zn}$ \\
\hline Bloco I & 12000 & 20000 & 12 & 13500 & 25500 & 15,8 \\
\hline Bloco II & 9000 & 20000 & 10 & 11000 & 25000 & 17,4 \\
\hline Bloco III & 9000 & 19000 & 10 & 13100 & 25400 & 19,1 \\
\hline $\begin{array}{l}\text { Média pleno } \\
\text { sol }\end{array}$ & $10000 \mathrm{a}$ & $20000 \mathrm{~b}$ & $11 \mathrm{a}$ & $12500 \mathrm{~b}$ & $25300 \mathrm{~b}$ & $17,4 \mathrm{a}$ \\
\hline
\end{tabular}

Os métodos de espectrometria de absorção atômica (1) e fotometria por emissão de chama (2) são comumente utilizados para análise foliar visando diagnosticar o estado nutricional da planta.

É possível comparar as concentrações elementares das folhas dos cafeeiros obtidas através de INAA ( $\mathrm{Ca}, \mathrm{K}$ e Zn), espectrometria de absorção atômica (Ca e Zn) e fotometria por emissão de chama $(\mathrm{K})$, uma vez que os três métodos avaliam as quantidades totais.

\subsection{Resultados de análise foliar da espécie arbórea Platycyamus regnellii}

Foram determinadas as concentrações de $\mathrm{N}, \mathrm{P}, \mathrm{K}, \mathrm{Ca}, \mathrm{Mg}, \mathrm{S}, \mathrm{Cu}, \mathrm{Fe}, \mathrm{Mn}$ e $\mathrm{Zn}$ nas folhas da espécie arbórea Platycyamus regnellii. Os resultados das médias dos blocos das folhas da espécie arbórea e seus desvios padrões se encontram na Tabela 11. 
Tabela 11. Média das concentrações foliares da espécie arbórea Platycyamus regnellii e desvio padrão

\begin{tabular}{lcccccccccc}
\hline & $\mathbf{N}$ & $\mathbf{P}$ & $\mathbf{K}$ & $\mathbf{C a}$ & $\mathbf{M g}$ & $\mathbf{S}$ & $\mathbf{C u}$ & $\mathbf{F e}$ & $\mathbf{M n}$ & $\mathbf{Z n}$ \\
\hline & $\mathrm{g} / \mathrm{kg}$ & $\mathrm{g} / \mathrm{kg}$ & $\mathrm{g} / \mathrm{kg}$ & $\mathrm{g} / \mathrm{kg}$ & $\mathrm{g} / \mathrm{kg}$ & $\mathrm{g} / \mathrm{kg}$ & $\mathrm{mg} / \mathrm{kg}$ & $\mathrm{mg} / \mathrm{kg}$ & $\mathrm{mg} / \mathrm{kg}$ & $\mathrm{mg} / \mathrm{kg}$ \\
Média Bloco I & 22,8 & 0,96 & 16,0 & 8,17 & 1,78 & 1,25 & 7,8 & 427 & 76,7 & 62,5 \\
DP Bloco I & 0,4879 & 0,0 & 0,509 & 0,3252 & 0,014 & 0,0707 & 0,466 & 28,36 & 1,499 & 12,6 \\
Média Bloco II & 22,3 & 0,835 & 17,4 & 7,68 & 1,62 & 1,03 & 9,04 & 349 & 111 & 17,9 \\
DP Bloco II & 1,421 & 0,035 & 0,1272 & 0,084 & 0,049 & 0,0282 & 0,3606 & 9,807 & 2,453 & 3,74 \\
Média Bloco III & 18,7 & 0,615 & 11,6 & 15,5 & 3,07 & 1,09 & 7,0 & 299 & 346 & 16,4 \\
DP Bloco III & 0,24 & 0,494 & 2,1566 & 1,16 & 0,035 & 0,098 & 0,134 & 16,83 & 31,25 & 5,536 \\
Média Geral & 21,3 & 0,803 & 15,0 & 10,5 & 2,15 & 1,12 & 7,94 & 358 & 178 & 32,3 \\
Folhas Árvore & & & & & & & & & & \\
DP Geral & 2,096 & 0,158 & 2,869 & 3,973 & 0,71 & 0,11 & 0,958 & 59,48 & 132,09 & 24,3 \\
Folhas Árvore & & & & & & & & & & \\
\hline
\end{tabular}

As folhas da espécie arbórea Platycyamus regnellii possuem quantidades consideráveis de nutrientes, sendo que estes provavelmente influenciaram na composição química elementar e na fertilidade do solo do sistema sombreado, conseqüentemente influenciando os outros parâmetros avaliados.

Tabela 12. Comparação entre INAA, espectrometria de absorção atômica (1) e fotometria por emissão de chama (2) para determinação dos nutrientes $\mathrm{Ca}, \mathrm{K}$ e Zn em folhas da espécie arbórea, Platycyamus regnellii

\begin{tabular}{lcccccc}
\hline & INAA $\left(\mu \mathbf{g ~ g}^{-\mathbf{1}}\right)$ & & $\mathbf{1}(\mathbf{m g} / \mathbf{k g})$ & $\mathbf{2}(\mathbf{m g} / \mathbf{k g})$ & $\mathbf{1}(\mathbf{m g} / \mathbf{k g})$ \\
\hline & $\mathrm{Ca}$ & $\mathrm{K}$ & $\mathrm{Zn}$ & $\mathrm{Ca}$ & $\mathrm{K}$ & $\mathrm{Zn}$ \\
Bloco I & 7130 & 16000 & 16,6 & 8,17 & 16,0 & 62,5 \\
Bloco II & 6050 & 16100 & 15,4 & 7,68 & 17,4 & 17,9 \\
Bloco III & 14500 & 7730 & 12,0 & 15,5 & 11,6 & 16,4 \\
Média sombreado & 9230 & 13200 & 14,6 & 10,5 & 15,0 & 32,3 \\
\hline
\end{tabular}

Os métodos de espectrometria de absorção atômica (1) e fotometria por emissão de chama (2) são comumente utilizados para análise foliar visando diagnosticar o estado nutricional da planta.

É possível comparar as concentrações elementares das folhas da espécie arbórea Platycyamus regnellii obtidas através de INAA (Ca, K e Zn), espectrometria de absorção atômica ( $\mathrm{Ca}$ e $\mathrm{Zn})$ e fotometria por emissão de chama $(\mathrm{K})$, uma vez que os três métodos avaliam as quantidades totais. 


\subsection{Qualidade do café}

Foram realizadas as seguintes análises para a determinação da qualidade do café: qualidade da bebida, classificação por tipo, tamanho dos grãos, rendimento do café após o benefício e quantidade de grãos verdes. As amostras analisadas apresentaram índices relacionados na Tabela 13.

Tabela 13. Média e desvio padrão de qualidade da bebida (dura=1, apenas mole=2, mole=3), porcentagem de grãos de café acima de peneira 14, tipo (em pontos), rendimento após o benefício em porcentagem e quantidade de grãos de café verdes (em amostras de $300 \mathrm{~g}$ ) nos dois tratamentos estudados

\begin{tabular}{|c|c|c|c|c|c|c|}
\hline \multicolumn{2}{|c|}{ Sombreado } & \multirow{2}{*}{$\begin{array}{c}\begin{array}{c}\text { Qualidade } \\
\text { bebida }\end{array} \\
2 \\
0,816\end{array}$} & \multirow{2}{*}{$\begin{array}{c}\% \\
\text { Peneira } \\
>\mathbf{1 4} \\
81,7 \\
2,23\end{array}$} & \multirow{2}{*}{$\begin{array}{c}\begin{array}{c}\text { Tipo em } \\
\text { pontos }\end{array} \\
-109 \\
20,56\end{array}$} & \multirow{2}{*}{$\begin{array}{c}\text { Rendimento } \\
\% \\
49,6 \\
1,30\end{array}$} & \multirow{2}{*}{$\begin{array}{c}\begin{array}{c}\text { Quantidade de } \\
\text { grãos verdes }\end{array} \\
40,5 \\
19,91\end{array}$} \\
\hline Bloco I & $\begin{array}{l}\text { Média } \\
\text { Desvio Padrão }\end{array}$ & & & & & \\
\hline Bloco II & $\begin{array}{l}\text { Média } \\
\text { Desvio Padrão }\end{array}$ & $\begin{array}{c}2 \\
1,154\end{array}$ & $\begin{array}{l}89,0 \\
1,47\end{array}$ & $\begin{array}{l}-32,5 \\
42,91\end{array}$ & $\begin{array}{l}45,3 \\
2,20\end{array}$ & $\begin{array}{l}7,25 \\
9,39\end{array}$ \\
\hline Bloco III & $\begin{array}{l}\text { Média } \\
\text { Desvio Padrão }\end{array}$ & $\begin{array}{c}1,5 \\
0,577\end{array}$ & $\begin{array}{l}84,1 \\
6,58\end{array}$ & $\begin{array}{l}-111 \\
20,56\end{array}$ & $\begin{array}{l}52,0 \\
1,78\end{array}$ & $\begin{array}{c}57,8 \\
18,55\end{array}$ \\
\hline \multicolumn{2}{|c|}{$\begin{array}{l}\text { Média sombreado }(\mathrm{n}=12) \\
\text { Desvio padrão }\end{array}$} & $\begin{array}{c}1,83 \mathrm{a} \\
0,8348\end{array}$ & $\begin{array}{c}84,9 \mathrm{a} \\
4,87\end{array}$ & $\begin{array}{c}-84,2 \mathrm{a} \\
46,8\end{array}$ & $\begin{array}{c}48,9 \mathrm{a} \\
3,33\end{array}$ & $\begin{array}{l}35,2 \mathrm{a} \\
26,16\end{array}$ \\
\hline \multicolumn{7}{|l|}{ Pleno Sol } \\
\hline Bloco I & $\begin{array}{l}\text { Média } \\
\text { Desvio Padrão }\end{array}$ & $\begin{array}{c}2 \\
0,8164\end{array}$ & $\begin{array}{l}84,2 \\
3,73\end{array}$ & $\begin{array}{l}-92,5 \\
79,21\end{array}$ & $\begin{array}{l}50,3 \\
3,57\end{array}$ & $\begin{array}{c}56 \\
58,66\end{array}$ \\
\hline Bloco II & $\begin{array}{l}\text { Média } \\
\text { Desvio Padrão }\end{array}$ & $\begin{array}{c}2 \\
0,8164\end{array}$ & $\begin{array}{c}84,4 \\
3,5\end{array}$ & $\begin{array}{c}-56,3 \\
33\end{array}$ & $\begin{array}{l}50,5 \\
1,18\end{array}$ & $\begin{array}{c}18,3 \\
20\end{array}$ \\
\hline Bloco III & $\begin{array}{l}\text { Média } \\
\text { Desvio Padrão }\end{array}$ & $\begin{array}{l}1 \\
0\end{array}$ & $\begin{array}{l}82,2 \\
2,75\end{array}$ & $\begin{array}{l}-119 \\
40,07\end{array}$ & $\begin{array}{l}53,4 \\
2,96\end{array}$ & $\begin{array}{c}66,8 \\
56,62\end{array}$ \\
\hline \multicolumn{2}{|c|}{$\begin{array}{l}\text { Média pleno sol }(\mathrm{n}=12) \\
\text { Desvio padrão }\end{array}$} & $\begin{array}{c}1,67 \mathrm{a} \\
0,77\end{array}$ & $\begin{array}{c}83,6 \mathrm{a} \\
3,22\end{array}$ & $\begin{array}{l}-89,2 \mathrm{a} \\
56,23\end{array}$ & $\begin{array}{c}51,4 \mathrm{~b} \\
2,92\end{array}$ & $\begin{array}{c}47 \mathrm{a} \\
48,93\end{array}$ \\
\hline
\end{tabular}

Médias seguidas pela mesma letra não diferem estatisticamente entre si pelo teste de Tukey em nível de $95 \%$ de confiança

Quando o café é comercializado, os principais quesitos observados pelos compradores e apreciadores são qualidade da bebida, tamanho dos grãos e quantidade de defeitos. 
Não foi observada diferença estatística significativa entre os sistemas para os parâmetros de qualidade da bebida, tamanho de grãos de café, tipo e quantidade de grãos verdes, embora resultados ligeiramente melhores foram encontrados para o sistema sombreado em todos estes parâmetros.

Ricci et al. (2002) obtiveram melhor tipo nos grãos de café robusta proveniente do sistema sombreado do que no sistema a pleno sol.

O tipo do café (quantidade de defeitos na amostra representativa do lote) pode ter grande influência na qualidade da bebida, uma vez que os grãos defeituosos (brocados, verdes, pretos, etc...) irão influenciar negativamente na bebida. Destacou-se aqui a quantidade de grãos verdes, pois este defeito é um dos que mais deprecia a qualidade da bebida de café.

Foi encontrada diferença estatística significativa para o parâmetro de rendimento relação em massa entre o café em coco e o café beneficiado-, sendo que o rendimento foi superior no sistema a pleno sol. Isto significa que para uma mesma quantidade de café em coco proveniente dos dois sistemas, será obtida uma maior quantidade de café beneficiado no a pleno sol.

Neste caso, o rendimento obtido foi inversamente proporcional à quantidade de defeitos verdes, uma vez que maior quantidade de grãos verdes foi encontrada nas parcelas do tratamento a pleno sol. Este fato pode ser explicado, pois a casca melosa (casca do grão quando em coco) do grão verde é menos volumosa, mais aderida ao grão resultando em uma casca mais leve. Então, pode-se afirmar que o defeito verde influencia não só no tipo e na bebida do café mas também no rendimento (média ideal na faixa de 50\% de rendimento para café em coco). O maior índice de rendimento foi obtido na amostra $n^{\circ} 23$ (pleno sol), que apresentou maior quantidade de grãos verdes. As amostras $n^{\circ} 11$ e 12 apresentaram as menores quantidades de grãos verdes (ambas do sistema sombreado) e tiveram os menores rendimentos, confirmando a afirmação anterior.

As amostras das parcelas 10 e 11 (sombreado) obtiveram melhores índices de peneira, corroborando a afirmação de Matiello (1995) que verificou em um experimento com seringueira que as plantas de café que sofriam influência da sombra sempre apresentaram frutos mais graúdos, sem chochamento e com boa qualidade de grãos. Estas parcelas também apresentaram bebida mole. Existe uma tendência à superioridade do 
sistema sombreado para qualidade da bebida e tamanho dos grãos, confirmando resultados de Matiello (1985) e Fernandes (1996), que mostram que em cafezais sombreados os frutos de café são maiores, mais moles, mais açucarados, mais suaves e, portanto, de qualidade superior. Os atributos de qualidade do café para cada parcela podem ser visualizados no Anexo K.

Foi visualizado na colheita dos grãos do sistema sombreado que estes se apresentavam mais cereja e com menos grãos secos e verdes. Fernandes (1986) e Matiello et al. (2002) confirmam que os frutos de cafés sombreados maturam mais lentamente, permanecendo mais tempo no estado de cereja, facilitando a colheita e favorecendo a qualidade.

Embora não apresente diferença estatística significativa para qualidade da bebida, tamanho dos grãos (peneira), tipo dos grãos e quantidade de grãos verdes, o sistema sombreado demonstra uma tendência àsuperioridade, que pode ser visualizada na Figura 12. 
Qualidade de bebida

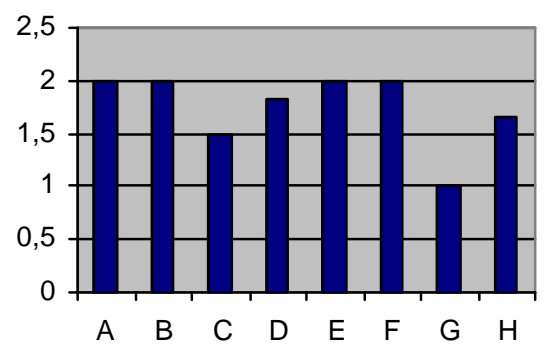

Tipo por pontos

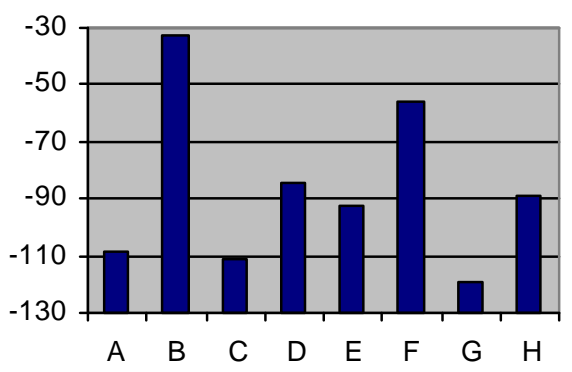

$\%$ Peneira $>14$

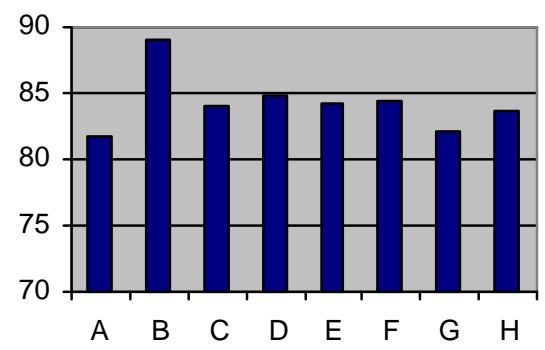

$\%$ Rendimento

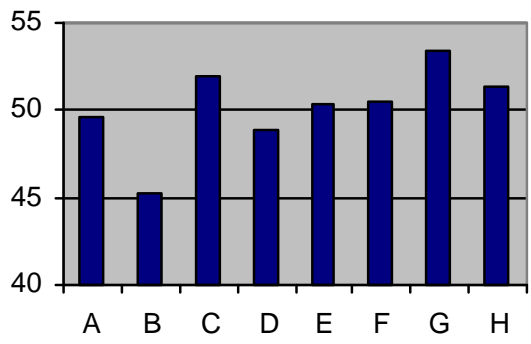

Quantidade grãos verdes

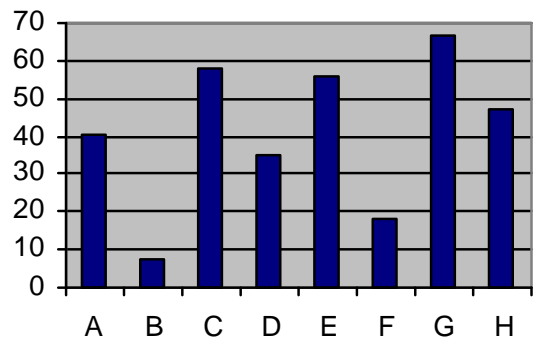

Figura 12 - Gráficos de qualidade da bebida (Dura $=1$, Apenas mole $=2$ e Mole $=3$ ), tamanho de grãos (\% peneira > 14), tipo por pontos (mais próximo de zero, melhor), porcentagem (\%) de rendimento no benefício e quantidade de grãos verdes em amostra de $300 \mathrm{~g}$. A) Média das parcelas do bloco I do tratamento sombreado; B) Média das parcelas do bloco II do tratamento sombreado; C) Média das parcelas do bloco III do tratamento sombreado; D) Média geral das parcelas do tratamento sombreado; E) Média das parcelas do bloco I do tratamento a pleno sol; F) Média das parcelas do bloco II do tratamento a pleno sol; G) Média das parcelas do bloco III do tratamento a pleno sol; H) Média geral das parcelas do tratamento a pleno sol. 


\subsection{Considerações finais}

A hipótese de discriminação de dois sistemas de produção de café sombreado e a pleno sol pela análise de grãos e folhas de café através de INAA, tanto por análise estatística multivariada ou univariada, apresentou um bom potencial. Os elementos que apresentaram maior contribuição para esta discriminação na PCA para grãos e folhas foram $\mathrm{Br}, \mathrm{Ca}, \mathrm{Cs}, \mathrm{K}$, $\mathrm{Rb}$ e $\mathrm{Zn}$. Estes resultados demonstraram ser possível discriminar cafés produzidos sob condições de pleno sol de cafés sombreados, baseando-se na análise química elementar dos grãos e folhas de café praticada em elevado nível metrológico.

A análise de solo através de INAA não apresentou potencial discriminatório. Esta perspectiva não positiva para discriminação dos sistemas pelos solos pode ser atribuída ao fato de ter-se amostrado o solo apenas a uma profundidade e esta ser muito profunda. Para trabalhos futuros, sugere-se a coleta de amostras de solo estratificada $(0-5 \mathrm{~cm}, 5-10 \mathrm{~cm}, 10$ $20 \mathrm{~cm}$ ) uma vez que na camada mais superficial $(0-5 \mathrm{~cm})$, provavelmente será notada maior influência da presença das árvores.

Para grãos de café, os resultados de INAA interpretados por estatística univariada pelo teste de Tukey, em nível de 95\% de confiança, demonstraram diferença entre os sistemas. O sistema sombreado apresentou as maiores concentrações de $\mathrm{K}$, enquanto o sistema a pleno sol concentrações maiores de $\mathrm{Cs}$ e $\mathrm{Br}$.

Já quanto à folhas de café provenientes dos dois sistemas de produção, também foram obtidas diferenças significativas para as concentrações elementares tanto por INAA quanto por análise foliar. Para INAA, a estatística univariada pelo teste de Tukey, em nível de $95 \%$ de confiança, demonstrou diferença entre os dois sistemas, sendo que para $\mathrm{K}$ e $\mathrm{Rb}$ o sistema sombreado apresentou as maiores concentrações, enquanto valores superiores para Cs foram observados a pleno sol.

No solo proveniente dos dois sistemas, os resultados interpretados através de análise estatística univariada por teste de Tukey em nível de 95\% de confiança demonstraram diferenças para fertilidade do solo, enquanto para INAA não foi verificada diferença significativa. Quanto à fertilidade do solo, foram obtidos maiores valores de $\mathrm{P}$ e $\mathrm{K}$ no sistema sombreado. 
Para qualidade do café, embora só verificada diferença estatística significativa quanto ao rendimento do café, superior no sistema a pleno sol, os outros parâmetros avaliados demonstraram uma tendência àsuperioridade do sistema sombreado.

Apesar de não ser observada diferença estatística significativa entre os valores de produtividade, o sistema sombreado obteve produtividade média ligeiramente maior. Observações de campo sugerem que árvores caducifólias no inverno, como a utilizada neste caso, permitem entrada de luz suficiente para uma indução floral e, conseqüentemente, uma florada intensa e boa produtividade do cafeeiro.

Fazendo uma interpretação mais abrangente dos resultados e os correlacionando, é possível dizer que as maiores concentrações do nutriente $\mathrm{K}$ observadas nos grãos por INAA, folhas por INAA e análise foliar e fertilidade do solo do sistema sombreado provavelmente influenciaram nos parâmetros de produtividade e qualidade de café. O K é considerado há muito tempo o elemento da qualidade em nutrição vegetal (Malavolta, 1989) além de ser importante durante o enchimento de grãos. Quando em deficiência, o crescimento e o enchimento dos grãos diminuem pois os açúcares e amidos se acumulam onde são formados (Mills \& Jones, 1997). Também melhora a resistência a pragas e doenças e a seca e ao frio (Matiello at al., 2002). Silva (2002) cita o K como o elemento mais importante na qualidade da bebida de café. Associando estas observações aos resultados encontrados no presente experimento pode-se dizer que o $\mathrm{K}$ deve ter tido influência na produtividade, qualidade de grãos (tipo), tamanho de grãos e qualidade da bebida.

Diferentemente do que era previsto, não houve diferença estatística significativa para os valores de matéria orgânica no solo dos dois sistemas. Tal fato pode ser devido àlavoura de café também contribuir com a matéria orgânica no solo através da decomposição de suas próprias folhas. Os cafeeiros a pleno sol perdem mais folhas que os sombreados, uma vez que o microclima a pleno sol é mais seco, e assim precisam reduzir a respiração no período de seca, derrubando suas folhas ao solo. Além disto, no sistema a pleno sol existe maior número de espécies espontâneas nas entrelinhas do café gerando maior massa vegetal. Já no cafezal sombreado, as espécies espontâneas, principalmente as gramíneas, são inibidas. Esta massa vegetal, conseqüência das espécies invasoras, nas entrelinhas do sistema a pleno sol contribui com o aumento da matéria orgânica do solo (Clarke \& Macrae, 1985b; Fernandes, 1986, Matiello et al., 2002). As espécies vegetais espontâneas vêm sendo tratadas como 
"plantas daninhas", "ervas invasoras", "inços" e outras denominações. Contudo, podem promover efeitos benéficos de proteção de solo, acúmulo de matéria orgânica e ciclagem de nutrientes (Favero et al., 2000).

Este fato pode explicar também os valores próximos encontrados para $\mathrm{N}$ nas folhas do cafeeiro dos dois sistemas, uma vez que o valor de $\mathrm{N}$ nas folhas pode ser relacionado com o valor de matéria orgânica no solo (Mills \& Jones, 1997; Raij, 1991).

$\mathrm{O}$ valor de $\mathrm{P}$ no solo obtido por fertilidade foi maior no sistema sombreado do que a pleno sol (respectivamente médio e baixo), contudo as concentrações de $\mathrm{P}$ obtidas na análise foliar não revelaram diferença entre os sistemas e nem deficiência deste elemento. Isto pode ter acontecido devido à ação dos microorganismos do solo que solubilizam fosfatos inorgânicos, desempenhando importante papel no suprimento de $\mathrm{P}$ para as plantas (Silva Filho \& Vidor, 2001). Outro fator que pode ter contribuído para este resultado é a presença de fungos micorrízicos arbusculares em cafezais, que influenciam positivamente na absorção de fósforo pelas plantas (Lopes et al., 1983). 


\section{CONCLUSÕES}

Nas condições que o experimento foi conduzido, permite-se chegar as seguintes conclusões:

O sistema sombreado apresentou resultados estatisticamente superiores que o sistema a pleno sol para as concentrações de K nos grãos (INAA), folhas (INAA e análise foliar) e solo (fertilidade). Estes resultados provavelmente tiveram influência positiva sobre os parâmetros de produtividade e qualidade de café do sistema sombreado.

As concentrações de $\mathrm{Br}$ e $\mathrm{Cs}$ nos grãos de café (INAA) foram superiores no tratamento a pleno sol, enquanto a de $\mathrm{K}$ foi maior no tratamento sombreado. Nas folhas do cafeeiro analisadas por INAA, os elementos $\mathrm{K}$ e Rb foram superiores no sistema sombreado, enquanto o Cs foi superior no a pleno sol. Estas diferenças auxiliaram na diferenciação destes dois sistemas de produção, através de análise multivariada (PCA) dos resultados da INAA.

Quanto à fertilidade do solo e $\mathrm{pH}$, ambos os sistemas apresentaram valores muito bons, com exceção de P e K cujos valores no sistema sombreado foram significativamente superiores, sendo respectivamente médio e bom, enquanto para a pleno sol foram respectivamente baixo e médio. Para a matéria orgânica do solo, ambos os sistemas apresentaram níveis médios.

Quanto à análise foliar ambos os sistemas apre sentaram valores muito bons para todos os nutrientes. Houve diferença significativa para $\mathrm{Ca}, \mathrm{K} \mathrm{e} \mathrm{Cu}$, sendo os dois primeiros superiores no sistema sombreado e o último superior no sistema a pleno sol.

As folhas da espécie arbórea Platycyamus regnellii sobre o solo do sistema sombreado e as raízes desta colaboraram para maiores concentrações de P e K no solo deste sistema. 
O rendimento (relação café em coco/café beneficiado) foi maior no sistema a pleno sol, provavelmente influenciado pela presença de um maior número de grãos verdes.

As temperaturas do solo e os valores para radiação solar foram superiores no sistema a pleno sol, demonstrando a real diferença entre os dois sistemas avaliados.

Quanto à produtividade, não houve diferença estatística significativa, embora o sistema sombreado tenha apresentado resultado ligeiramente maior.

Portanto, no geral, neste experimento o sistema de café orgânico sombreado apresentou melhores resultados que o sistema a pleno sol, justificando assim o seu uso. 


\section{ANEXOS}


Anexo A - Volume de café colhido (L) por parcela

\begin{tabular}{ccccc}
\hline & & Parcelas & Produção de café \\
Número & Bloco & Tratamento & Cardeal & colhido (L) \\
1 & I & Sombreado & Norte & 43 \\
2 & I & Sombreado & Sul & 60 \\
3 & I & Sombreado & Leste & 42 \\
4 & I & Sombreado & Oeste & 55 \\
5 & I & Pleno sol & Norte & 38 \\
6 & I & Pleno sol & Sul & 12 \\
7 & I & Pleno sol & Leste & 37 \\
8 & I & Pleno sol & Oeste & 52 \\
9 & II & Sombreado & Norte & 20 \\
10 & II & Sombreado & Sul & 12 \\
11 & II & Sombreado & Leste & 10 \\
12 & II & Sombreado & Oeste & 10 \\
13 & II & Pleno sol & Norte & 46 \\
14 & II & Pleno sol & Sul & 05 \\
15 & II & Pleno sol & Leste & 45 \\
16 & II & Pleno sol & Oeste & 26 \\
17 & III & Sombreado & Norte & 26 \\
18 & III & Sombreado & Sul & 48 \\
19 & III & Sombreado & Leste & 65 \\
20 & III & Sombreado & Oeste & 36 \\
21 & III & Pleno sol & Norte & 34 \\
22 & III & Pleno sol & Sul & 11 \\
23 & III & Pleno sol & Leste & 33 \\
24 & III & Pleno sol & Oeste & 68 \\
\hline
\end{tabular}


Anexo B - Tabela de equivalência de grãos imperfeitos e impurezas

\begin{tabular}{cc}
\hline GRÃOS IMPERFEITOS E IMPUREZAS & DEFEITOS \\
\hline 1 grão preto & 1 \\
1 pedra, pau ou torrão grande & 5 \\
1 pedra, pau ou torrão regular & 2 \\
1 pedra, pau ou torrão pequeno & 1 \\
1 coco & 1 \\
1 casca grande & 1 \\
2 ardidos & 1 \\
2 marinheiros & 1 \\
2 a 3 cascas pequenas & 1 \\
2 a 5 brocados & 1 \\
3 conchas & 1 \\
5 verdes & 1 \\
5 quebrados & 1 \\
5 chochos ou mal granados & 1 \\
\hline
\end{tabular}


Anexo C - Tabela oficial para classificação de tipos de café

\begin{tabular}{|c|c|c|}
\hline Defeitos & Tipos & Pontos \\
\hline 4 & 2 & +100 \\
\hline 4 & $2-05$ & +95 \\
\hline 5 & $2-10$ & +90 \\
\hline 6 & $2-15$ & +85 \\
\hline 7 & $2-20$ & +80 \\
\hline 8 & $2-25$ & +75 \\
\hline 9 & $2-30$ & +70 \\
\hline 10 & $2-35$ & +65 \\
\hline 11 & $2-40$ & +60 \\
\hline 11 & $2-45$ & +55 \\
\hline 12 & 3 & +50 \\
\hline 13 & $3-5$ & +45 \\
\hline 15 & $3-10$ & +40 \\
\hline 17 & $3-15$ & +35 \\
\hline 18 & $3-20$ & +30 \\
\hline 19 & $3-25$ & +25 \\
\hline 20 & $3-30$ & +20 \\
\hline 22 & $3-35$ & +15 \\
\hline 23 & $3-40$ & +10 \\
\hline 25 & $3-45$ & +5 \\
\hline 26 & 4 & BASE \\
\hline 28 & $4-5$ & -5 \\
\hline 30 & $4-10$ & -10 \\
\hline 32 & $4-15$ & -15 \\
\hline 34 & $4-20$ & -20 \\
\hline 36 & $4-25$ & -25 \\
\hline 38 & $4-30$ & -30 \\
\hline 40 & $4-35$ & -35 \\
\hline 42 & $4-40$ & -40 \\
\hline 44 & $4-45$ & -45 \\
\hline 46 & 5 & -50 \\
\hline 49 & $5-5$ & -55 \\
\hline 53 & $5-10$ & -60 \\
\hline 57 & $5-15$ & -65 \\
\hline 61 & $5-20$ & -70 \\
\hline 64 & $5-25$ & -75 \\
\hline 68 & $5-30$ & -80 \\
\hline 71 & $5-35$ & -85 \\
\hline 75 & $5-40$ & -90 \\
\hline
\end{tabular}




\begin{tabular}{ccc}
\hline Defeitos & Tipos & Pontos \\
\hline 79 & $5-45$ & -95 \\
86 & 6 & -100 \\
93 & $6-5$ & -105 \\
100 & $6-10$ & -110 \\
108 & $6-15$ & -115 \\
115 & $6-20$ & -120 \\
123 & $6-25$ & -125 \\
130 & $6-30$ & -130 \\
138 & $6-35$ & -135 \\
145 & $6-40$ & -140 \\
153 & $6-45$ & -145 \\
160 & 7 & -150 \\
180 & $7-5$ & -155 \\
200 & $7-10$ & -160 \\
220 & $7-15$ & -165 \\
240 & $7-20$ & -170 \\
260 & $7-25$ & -175 \\
280 & $7-30$ & -180 \\
300 & $7-35$ & -185 \\
320 & $7-40$ & -190 \\
340 & $7-45$ & -195 \\
360 & 8 & -200 \\
\hline
\end{tabular}


Anexo D - Dados de Fertilidade, pH e Matéria orgânica do solo de cada parcela

\begin{tabular}{|c|c|c|c|c|c|c|c|c|c|c|c|}
\hline & $\mathrm{CaCl} 2$ & $\mathrm{P}$ & $\mathrm{MO}$ & $\mathrm{Ca}$ & $\mathrm{Mg}$ & $\mathrm{K}$ & $\mathrm{Al}+\mathrm{H}$ & $\mathrm{Cu}$ & $\mathrm{Fe}$ & $\overline{M n}$ & $\mathrm{Zn}$ \\
\hline & PH & $\mathrm{mg} \mathrm{dm}$ & $\begin{array}{l}\mathrm{mmol} \\
\mathrm{dm}^{-3}\end{array}$ & $\begin{array}{l}\mathrm{mmol} \\
\mathrm{dm}^{-3}\end{array}$ & $\begin{array}{l}\mathrm{mmol} \\
\mathrm{dm}^{-3}\end{array}$ & $\begin{array}{l}\mathrm{mmol} \\
\mathrm{dm}^{-3}\end{array}$ & $\begin{array}{l}\mathrm{mmol} \\
\mathrm{dm}^{-3}\end{array}$ & $\mathrm{mg} \mathrm{kg}_{-1}$ & $\underset{1}{\mathrm{mg} \mathrm{kg}}$ & $\underset{-1}{\mathrm{mg}} \mathrm{kg}$ & $\underset{-1}{\mathrm{mg} \mathrm{kg}}$ \\
\hline 1 & 5,53 & 12,87 & 23,96 & 51,22 & 19,3 & 3,16 & 28,34 & 5,1 & 58,95 & 9,87 & 5,2 \\
\hline 2 & 6,18 & 8,8 & 21,14 & 69,66 & 27,95 & 3,52 & 18,21 & 3,85 & 43,02 & 7,94 & 4,3 \\
\hline 3 & 6,55 & 17,27 & 19,73 & 68,62 & 30,31 & 2,64 & 14,91 & 1,95 & 28,52 & 5,07 & 3,18 \\
\hline 4 & 6,69 & 21,67 & 32,41 & 95,99 & 38,39 & 2,64 & 14,3 & 4,9 & 27,47 & 7,64 & 6,7 \\
\hline 5 & 6,52 & 10,83 & 23,37 & 78,46 & 34,64 & 3,45 & 14,76 & 4,36 & 30,17 & 6,53 & 6 \\
\hline 6 & 5,76 & 9,82 & 22,55 & 56,17 & 26,76 & 1,39 & 27,46 & 2,42 & 51,72 & 5,74 & 1,95 \\
\hline 7 & 6,71 & 13,21 & 19,73 & 93,01 & 44,01 & 1,17 & 13,42 & 7,6 & 26,22 & 6,32 & 7,6 \\
\hline 8 & 6,6 & 13,21 & 21,14 & 84,43 & 37,94 & 1,39 & 14,76 & 2,57 & 26,99 & 4,54 & 3,8 \\
\hline 9 & 5,21 & 24,04 & 25,37 & 43,56 & 19,99 & 4,7 & 34,26 & 2,7 & 83,41 & 4,72 & 2,68 \\
\hline 10 & 5,34 & 8,46 & 25,37 & 53,69 & 23,06 & 2,57 & 36,88 & 3,06 & 99,86 & 4,91 & 2,65 \\
\hline 11 & 6,22 & 7,11 & 23,96 & 82,31 & 44,17 & 2,2 & 18,8 & 2,79 & 52,6 & 5,66 & 2,87 \\
\hline 12 & 5,29 & 8,13 & 23,96 & 50,1 & 24,2 & 3,08 & 38,47 & 3,19 & 90,87 & 5,37 & 2,63 \\
\hline 13 & 5,48 & 8,46 & 22,55 & 60,47 & 22,61 & 1,76 & 31,16 & 3,46 & 64,14 & 8,08 & 4 \\
\hline 14 & 5,49 & 9,82 & 25,37 & 67,1 & 27,85 & 2,06 & 34,99 & 2,9 & 87,6 & 2,45 & 1,98 \\
\hline 15 & 5,47 & 8,46 & 22,55 & 62,91 & 33,64 & 1,17 & 35,36 & 2,21 & 73,37 & 5,77 & 2,26 \\
\hline 16 & 5,51 & 7,11 & 22,55 & 67,7 & 34,95 & 1,32 & 33,19 & 5,26 & 82,62 & 3,62 & 3,18 \\
\hline 17 & 5,68 & 14,9 & 29,59 & 84,6 & 28,02 & 2,57 & 28,95 & 8,14 & 64,81 & 6,12 & 7,7 \\
\hline 18 & 4,98 & 11,85 & 22,55 & 44,88 & 17,6 & 3,89 & 52,21 & 5,58 & 98,56 & 4,14 & 3,42 \\
\hline 19 & 4,79 & 8,46 & 28,18 & 46,95 & 18,57 & 2,57 & 52,76 & 4,35 & 98,29 & 3,8 & 4,3 \\
\hline 20 & 5,92 & 21,33 & 25,37 & 100,1 & 29,35 & 3,23 & 24,2 & 6,3 & 62,75 & 8,07 & 7,9 \\
\hline 21 & 6,04 & 7,45 & 22,55 & 86,15 & 38,94 & 1,32 & 40,55 & 3,92 & 43,01 & 4,6 & 4,1 \\
\hline 22 & 5,18 & 8,13 & 33,82 & 59,23 & 32,25 & 0,95 & 54,45 & 4,03 & 127,6 & 1,96 & 2,85 \\
\hline 23 & 5,43 & 11,85 & 28,18 & 69,84 & 28,95 & 1,1 & 38,87 & 7,46 & 95,01 & 3,42 & 5 \\
\hline 24 & 5,88 & 5,08 & 22,55 & 62,18 & 29,24 & 1,25 & 22,48 & 3,71 & 44,96 & 4,73 & 4,1 \\
\hline
\end{tabular}


Anexo E - Dados de Análise foliar dos cafeeiros de cada parcela e da espécie arbórea Platycyamus regnellii

\begin{tabular}{|c|c|c|c|c|c|c|c|c|c|c|}
\hline & $\begin{array}{c}\mathrm{N} \\
\mathrm{g} / \mathrm{kg}\end{array}$ & $\begin{array}{c}\mathrm{P} \\
\mathrm{g} / \mathrm{kg}\end{array}$ & $\begin{array}{c}\mathrm{K} \\
\mathrm{g} / \mathrm{kg}\end{array}$ & $\begin{array}{c}\mathrm{Ca} \\
\mathrm{g} / \mathrm{kg}\end{array}$ & $\begin{array}{l}\mathrm{Mg} \\
\mathrm{g} / \mathrm{kg}\end{array}$ & $\begin{array}{c}\mathrm{S} \\
\mathrm{g} / \mathrm{kg}\end{array}$ & $\begin{array}{c}\mathrm{Cu} \\
\mathrm{mg} / \mathrm{kg}\end{array}$ & $\begin{array}{c}\mathrm{Fe} \\
\mathrm{mg} / \mathrm{kg}\end{array}$ & $\begin{array}{c}\mathrm{Mn} \\
\mathrm{mg} / \mathrm{kg}\end{array}$ & $\begin{array}{c}\mathrm{Zn} \\
\mathrm{mg} / \mathrm{kg}\end{array}$ \\
\hline \multicolumn{11}{|c|}{ Folhas de Cafeeiro } \\
\hline 1 & 26,03 & 1,86 & 31,94 & 11,94 & 6,08 & 1,9 & 10,64 & 141,52 & 39,69 & 15,49 \\
\hline 2 & 28,17 & 1,81 & 30,59 & 16,98 & 6,81 & 1,71 & 12,36 & 112,53 & 45,43 & 14,24 \\
\hline 3 & 27,75 & 1,86 & 30,14 & 19,98 & 7,37 & 1,99 & 11,47 & 131,83 & 45,62 & 22,38 \\
\hline 4 & 27,62 & 1,64 & 28,34 & 17,95 & 6,7 & 1,95 & 10,4 & 119,51 & 41,93 & 14,34 \\
\hline 5 & 28,65 & 1,76 & 26,54 & 12,32 & 4,86 & 1,99 & 16,68 & 115,39 & 36,8 & 9,24 \\
\hline 6 & 29,41 & 1,67 & 26,54 & 10,7 & 6,23 & 1,73 & 13,12 & 129,71 & 41,71 & 10,9 \\
\hline 7 & 26,86 & 1,88 & 22,49 & 15,72 & 6,77 & 2,2 & 21,64 & 72,72 & 40,57 & 11,2 \\
\hline 8 & 27,13 & 2,01 & 26,54 & 15,09 & 7,07 & 1,91 & 15,07 & 117,39 & 41,08 & 31,89 \\
\hline 9 & 27,34 & 1,97 & 32,39 & 12,3 & 6,21 & 1,92 & 12,09 & 132,79 & 50,08 & 11,05 \\
\hline 10 & 27,89 & 1,48 & 30,59 & 11,31 & 5,33 & 2,03 & 12,79 & 123,98 & 59,68 & 23,57 \\
\hline 11 & 29,48 & 1,69 & 28,34 & 11,64 & 5,58 & 1,9 & 14,38 & 133,77 & 46,54 & 10,9 \\
\hline 12 & 28,38 & 1,7 & 32,84 & 13,65 & 5,48 & 2 & 11,47 & 134,44 & 48,46 & 12,29 \\
\hline 13 & 26,65 & 1,62 & 24,29 & 13,22 & 5,44 & 1,85 & 14,38 & 79,17 & 62,43 & 10,98 \\
\hline 14 & 27,2 & 1,74 & 26,99 & 9,43 & 4,74 & 2,84 & 20,08 & 105,22 & 34,22 & 14,52 \\
\hline 15 & 27,55 & 1,62 & 23,39 & 10,54 & 5,96 & 1,69 & 13,11 & 115,4 & 89,23 & 34,92 \\
\hline 16 & 28,1 & 1,65 & 25,19 & 10,76 & 6,59 & 1,87 & 16,29 & 98,61 & 38,81 & 9,31 \\
\hline 17 & 26,37 & 1,64 & 34,63 & 11,97 & 5,58 & 1,98 & 13,7 & 125,24 & 48,54 & 32,66 \\
\hline 18 & 26,58 & 1,68 & 32,39 & 16,86 & 6,67 & 1,92 & 9,52 & 122,74 & 56,87 & 11,81 \\
\hline 19 & 25,34 & 1,53 & 29,69 & 15,86 & 6,36 & 1,68 & 8,97 & 88,5 & 46,82 & 11,14 \\
\hline 20 & 27,13 & 1,53 & 36,88 & 14,92 & 5,22 & 2,13 & 10,06 & 112,86 & 47,21 & 13,62 \\
\hline 21 & 26,1 & 1,53 & 26,54 & 16,92 & 7,03 & 1,86 & 13,19 & 100,55 & 47,22 & 11,18 \\
\hline 22 & 26,17 & 1,55 & 15,74 & 10,94 & 6,72 & 1,79 & 17,59 & 164,21 & 31,08 & 13,99 \\
\hline 23 & 29,27 & 1,48 & 31,04 & 13 & 6,22 & 2,37 & 14,19 & 124,81 & 63,87 & 19,3 \\
\hline 24 & 24,3 & 1,45 & 28,34 & 11,68 & 5,19 & 1,64 & 12,66 & 169,99 & 45,14 & 31,77 \\
\hline \multicolumn{11}{|c|}{ Folhas de árvore } \\
\hline $1 \mathrm{~A}$ & 22,44 & 0,96 & 16,37 & 8,4 & 1,79 & 1,2 & 8,13 & 446,8 & 77,74 & 71,43 \\
\hline 1B & 23,13 & 0,96 & 15,65 & 7,94 & 1,77 & 1,3 & 7,47 & 406,68 & 75,62 & 53,61 \\
\hline $2 \mathrm{~A}$ & 21,33 & 0,81 & 17,45 & 7,74 & 1,58 & 1,01 & 9,29 & 342,46 & 112,51 & 20,5 \\
\hline $2 B$ & 23,34 & 0,86 & 17,27 & 7,62 & 1,65 & 1,05 & 8,78 & 356,33 & 109,04 & 15,21 \\
\hline $3 \mathrm{~A}$ & 18,91 & 0,65 & 13,13 & 14,71 & 3,04 & 1,16 & 7,09 & 287,31 & 324,26 & 12,49 \\
\hline $3 B$ & 18,57 & 0,58 & 10,08 & 16,36 & 3,09 & 1,02 & 6,9 & 311,12 & 368,46 & 20,32 \\
\hline
\end{tabular}


Anexo F - Composição química elementar média $\left(\mu \mathrm{g} \mathrm{g}^{-1}\right)$ em grãos de café orgânico de sistema sombreado e de sistema a pleno sol

\begin{tabular}{ccccccccccc}
\hline Parcela & Trat & $\mathbf{B r}$ & $\mathbf{C a}$ & $\mathbf{C o}$ & $\mathbf{C s}$ & $\mathbf{F e}$ & $\mathbf{K}$ & $\mathbf{N a}$ & $\mathbf{R b}$ & $\mathbf{Z n}$ \\
\hline $\mathbf{1}$ & Arvore & 0,50 & 1220 & 0,03 & 0,04 & 25,30 & 16800 & 34,30 & 33,20 & 7,49 \\
$\mathbf{2}$ & Árvore & 0,49 & 1050 & 0,03 & 0,04 & 25,70 & 16100 & 19,00 & 38,80 & 6,46 \\
$\mathbf{3}$ & Árvore & 0,57 & 1270 & 0,00 & 0,01 & 19,50 & 16300 & 6,78 & 31,70 & 5,37 \\
$\mathbf{4}$ & Árvore & 0,47 & 1350 & 0,04 & 0,04 & 24,60 & 17800 & 8,44 & 31,90 & 7,46 \\
$\mathbf{9}$ & Árvore & 0,57 & 1060 & 0,03 & 0,03 & 23,40 & 16300 & 4,87 & 28,30 & 9,15 \\
$\mathbf{1 0}$ & Árvore & 0,59 & 1060 & 0,03 & 0,03 & 27,00 & 15200 & 6,21 & 32,60 & 8,64 \\
$\mathbf{1 1}$ & Árvore & 0,44 & 910 & 0,04 & 0,03 & 29,20 & 14400 & 3,96 & 28,50 & 7,74 \\
$\mathbf{1 2}$ & Árvore & 0,48 & 999 & 0,04 & 0,03 & 29,60 & 15400 & 5,37 & 30,10 & 7,07 \\
$\mathbf{1 7}$ & Árvore & 0,56 & 1190 & 0,07 & 0,06 & 23,30 & 16800 & 5,44 & 38,90 & 7,16 \\
$\mathbf{1 8}$ & Árvore & 0,58 & 1210 & 0,06 & 0,04 & 22,80 & 16500 & 3,50 & 35,10 & 6,66 \\
$\mathbf{1 9}$ & Árvore & 0,56 & 1160 & 0,02 & 0,05 & 21,40 & 15600 & 4,10 & 37,20 & 6,07 \\
$\mathbf{2 0}$ & Árvore & 0,67 & 1160 & 0,00 & 0,05 & 22,30 & 16800 & 4,10 & 35,20 & 6,71 \\
$\mathbf{5}$ & Sol & 0,33 & 1120 & 0,05 & 0,05 & 25,90 & 15900 & 5,30 & 32,20 & 7,89 \\
$\mathbf{6}$ & Sol & 0,48 & 1050 & 0,04 & 0,03 & 26,30 & 13300 & 8,97 & 29,90 & 6,31 \\
$\mathbf{7}$ & Sol & 0,60 & 1370 & 0,07 & 0,06 & 22,50 & 15900 & 8,91 & 34,20 & 8,76 \\
$\mathbf{8}$ & Sol & 0,33 & 1300 & 0,03 & 0,05 & 21,40 & 16200 & 7,02 & 34,80 & 6,53 \\
$\mathbf{1 3}$ & Sol & 0,85 & 980 & 0,05 & 0,05 & 24,90 & 14100 & 4,60 & 34,70 & 6,54 \\
$\mathbf{1 4}$ & Sol & 0,61 & 957 & 0,00 & 0,00 & 23,20 & 15800 & 5,16 & 26,20 & 8,36 \\
$\mathbf{1 5}$ & Sol & 1,15 & 898 & 0,03 & 0,05 & 28,10 & 15500 & 4,88 & 35,00 & 6,41 \\
$\mathbf{1 6}$ & Sol & 0,78 & 1030 & 0,05 & 0,04 & 22,40 & 15700 & 3,88 & 28,50 & 6,28 \\
$\mathbf{2 1}$ & Sol & 0,64 & 1140 & 0,06 & 0,07 & 21,60 & 14800 & 4,21 & 33,60 & 6,22 \\
$\mathbf{2 2}$ & Sol & 0,87 & 941 & 0,01 & 0,03 & 23,40 & 12600 & 3,33 & 30,80 & 6,00 \\
$\mathbf{2 3}$ & Sol & 1,02 & 1120 & 0,05 & 0,05 & 24,00 & 16200 & 3,14 & 29,20 & 7,33 \\
$\mathbf{2 4}$ & Sol & 0,81 & 1090 & 0,05 & 0,06 & 22,80 & 15600 & 3,74 & 37,00 & 6,80 \\
\hline
\end{tabular}


Anexo G - Composição química elementar média $\left(\mu \mathrm{g} \mathrm{g}^{-1}\right)$ em folhas de cafeeiros orgânicos de sistema sombreado e de sistema a pleno sol

\begin{tabular}{ccccccccc}
\hline Parcela & Trat & $\mathbf{B r}$ & $\mathbf{C a}$ & $\mathbf{C s}$ & $\mathbf{K}$ & $\mathbf{N a}$ & $\mathbf{R b}$ & $\mathbf{Z n}$ \\
\hline $\mathbf{1}$ & Arvore & 4,58 & 10500 & 0,07 & 32400 & 53,40 & 40,40 & 12,60 \\
$\mathbf{2}$ & Árvore & 1,97 & 11000 & 0,07 & 26700 & 34,00 & 28,60 & 10,50 \\
$\mathbf{3}$ & Árvore & 2,56 & 12900 & 0,07 & 27400 & 28,40 & 28,00 & 12,00 \\
$\mathbf{4}$ & Árvore & 2,47 & 12400 & 0,09 & 25300 & 32,80 & 29,80 & 12,40 \\
$\mathbf{9}$ & Árvore & 4,05 & 11800 & 0,06 & 29200 & 37,40 & 29,80 & 10,60 \\
$\mathbf{1 0}$ & Árvore & 2,45 & 9910 & 0,08 & 25500 & 27,70 & 31,10 & 11,30 \\
$\mathbf{1 1}$ & Árvore & 2,31 & 7690 & 0,06 & 21700 & 19,90 & 20,70 & 10,40 \\
$\mathbf{1 2}$ & Árvore & 2,46 & 9760 & 0,06 & 29400 & 44,30 & 37,40 & 12,10 \\
$\mathbf{1 7}$ & Árvore & 2,79 & 9420 & 0,08 & 28200 & 29,10 & 32,80 & 10,90 \\
$\mathbf{1 8}$ & Árvore & 3,32 & 13000 & 0,06 & 29600 & 32,00 & 30,40 & 10,90 \\
$\mathbf{1 9}$ & Árvore & 3,04 & 11500 & 0,06 & 25400 & 21,20 & 24,80 & 11,40 \\
$\mathbf{2 0}$ & Árvore & 5,42 & 10300 & 0,09 & 32800 & 28,90 & 35,60 & 11,20 \\
$\mathbf{5}$ & Sol & 3,56 & 9660 & 0,10 & 23700 & 37,60 & 23,00 & 9,69 \\
$\mathbf{6}$ & Sol & 4,15 & 16700 & 0,12 & 26400 & 26,80 & 30,10 & 12,60 \\
$\mathbf{7}$ & Sol & 2,75 & 11800 & 0,07 & 17100 & 17,20 & 17,80 & 10,40 \\
$\mathbf{8}$ & Sol & 2,64 & 11600 & 0,08 & 20700 & 22,60 & 24,30 & 16,20 \\
$\mathbf{1 3}$ & Sol & 4,42 & 10100 & 0,06 & 19200 & 18,50 & 16,90 & 8,91 \\
$\mathbf{1 4}$ & Sol & 5,02 & 7740 & 0,07 & 21000 & 20,30 & 19,90 & 10,90 \\
$\mathbf{1 5}$ & Sol & 3,76 & 9000 & 0,08 & 18100 & 24,70 & 21,10 & 10,40 \\
$\mathbf{1 6}$ & Sol & 4,50 & 9370 & 0,09 & 21900 & 32,90 & 21,80 & 9,79 \\
$\mathbf{2 1}$ & Sol & 2,10 & 7070 & 0,05 & 16800 & 34,60 & 21,80 & 7,54 \\
$\mathbf{2 2}$ & Sol & 3,35 & 8920 & 0,14 & 10700 & 18,80 & 10,70 & 9,87 \\
$\mathbf{2 3}$ & Sol & 4,98 & 9850 & 0,14 & 25700 & 66,10 & 29,30 & 11,30 \\
$\mathbf{2 4}$ & Sol & 3,19 & 9620 & 0,09 & 21500 & 24,80 & 20,80 & 10,00 \\
\hline
\end{tabular}


Anexo H - Composição química elementar média $\left(\mu \mathrm{g} \mathrm{g}^{-1}\right)$ de folhas da espécie arbórea Platycyamus regnellii

\begin{tabular}{ccccccccccccc} 
Parcela & $\mathbf{B a}$ & $\mathbf{B r}$ & $\mathbf{C a}$ & $\mathbf{C o}$ & $\mathbf{C r}$ & $\mathbf{C s}$ & $\mathbf{F e}$ & $\mathbf{K}$ & $\mathbf{N a}$ & $\mathbf{R b}$ & $\mathbf{S c}$ & $\mathbf{Z n}$ \\
\hline 1A & 17,70 & 1,71 & 6630 & 0,20 & 4,35 & 0,13 & 409 & 16600 & 48,70 & 21,80 & 0,08 & 16,00 \\
1B & 23,30 & 1,76 & 7630 & 0,27 & 4,65 & 0,11 & 601 & 15300 & 62,20 & 21,30 & 0,15 & 17,20 \\
2A & 14,50 & 6,18 & 6410 & 0,27 & 3,83 & 0,16 & 465 & 14700 & 69,80 & 19,50 & 0,05 & 15,80 \\
2B & 12,10 & 6,71 & 5680 & 0,28 & 3,54 & 0,18 & 380 & 17400 & 55,10 & 23,80 & 0,04 & 14,90 \\
3A & 17,00 & 1,26 & 14900 & 0,21 & 3,56 & 0,21 & 284 & 7550 & 59,10 & 12,80 & 0,06 & 11,10 \\
3B & 20,90 & 1,44 & 14100 & 0,20 & 3,93 & 0,18 & 366 & 7900 & 59,00 & 12,10 & 0,09 & 12,80 \\
\hline
\end{tabular}


Anexo I - Composição química elementar média $\left(\mu \mathrm{g} \mathrm{g}^{-1}\right)$ em solos de cafeeiros orgânicos de sistema sombreado e de sistema a pleno sol

\begin{tabular}{ccccccccccc}
\hline Parcela & Trat & $\mathbf{B r}$ & $\mathbf{C a}$ & $\mathbf{C o}$ & $\mathbf{C s}$ & $\mathbf{F e}$ & $\mathbf{N a}$ & $\mathbf{R b}$ & $\mathbf{S c}$ & $\mathbf{Z n}$ \\
\hline $\mathbf{1}$ & Arvore & 8,38 & 60900 & 3,81 & 1,32 & 44000 & 170,00 & 21,30 & 12,30 & 58,00 \\
$\mathbf{2}$ & Árvore & 8,81 & 45400 & 5,26 & 1,26 & 48400 & 84,00 & 20,60 & 13,50 & 62,10 \\
$\mathbf{3}$ & Árvore & 9,21 & 48500 & 3,77 & 1,23 & 44400 & 91,80 & 0,00 & 12,60 & 54,00 \\
$\mathbf{4}$ & Árvore & 7,36 & 46700 & 4,06 & 1,39 & 43300 & 84,70 & 0,00 & 11,70 & 64,60 \\
$\mathbf{9}$ & Árvore & 11,6 & 45500 & 3,95 & 1,53 & 39400 & 92,50 & 24,20 & 11,50 & 52,10 \\
$\mathbf{1 0}$ & Árvore & 11,8 & 42000 & 3,96 & 1,78 & 40000 & 97,00 & 22,20 & 11,60 & 55,50 \\
$\mathbf{1 1}$ & Árvore & 10,8 & 32500 & 3,93 & 1,56 & 38500 & 102,00 & 22,80 & 10,90 & 54,70 \\
$\mathbf{1 2}$ & Árvore & 11,9 & 47800 & 3,93 & 1,65 & 40300 & 87,50 & 21,00 & 12,00 & 47,90 \\
$\mathbf{1 7}$ & Árvore & 11,9 & 59400 & 5,79 & 1,77 & 59400 & 101,00 & 0,00 & 17,10 & 82,90 \\
$\mathbf{1 8}$ & Árvore & 12,6 & 69100 & 5,81 & 1,78 & 62400 & 85,60 & 16,50 & 17,40 & 70,40 \\
$\mathbf{1 9}$ & Árvore & 13,5 & 52200 & 23,50 & 1,57 & 61600 & 89,90 & 0,00 & 17,50 & 71,30 \\
$\mathbf{2 0}$ & Árvore & 11,6 & 61700 & 5,36 & 1,59 & 55300 & 86,50 & 15,50 & 15,70 & 81,20 \\
$\mathbf{5}$ & Sol & 7,85 & 46100 & 3,71 & 1,27 & 47400 & 158,00 & 28,10 & 13,20 & 70,80 \\
$\mathbf{6}$ & Sol & 10,6 & 59900 & 4,11 & 1,48 & 50800 & 104,00 & 22,10 & 13,90 & 60,50 \\
$\mathbf{7}$ & Sol & 9,08 & 61400 & 4,76 & 1,23 & 59000 & 116,00 & 24,10 & 17,40 & 81,60 \\
$\mathbf{8}$ & Sol & 8,32 & 51300 & 4,11 & 1,29 & 49100 & 105,00 & 18,00 & 12,70 & 59,40 \\
$\mathbf{1 3}$ & Sol & 8,81 & 36600 & 5,51 & 1,71 & 42800 & 105,00 & 21,80 & 12,50 & 60,00 \\
$\mathbf{1 4}$ & Sol & 13,1 & 47900 & 4,27 & 1,87 & 41400 & 88,00 & 18,20 & 12,70 & 51,50 \\
$\mathbf{1 5}$ & Sol & 11,6 & 44000 & 3,58 & 1,63 & 39000 & 92,50 & 23,50 & 10,80 & 52,40 \\
$\mathbf{1 6}$ & Sol & 11,9 & 46400 & 4,73 & 1,56 & 48800 & 85,60 & 23,20 & 14,60 & 57,00 \\
$\mathbf{2 1}$ & Sol & 9,55 & 54800 & 6,32 & 1,57 & 59800 & 91,40 & 0,00 & 15,90 & 70,30 \\
$\mathbf{2 2}$ & Sol & 18,3 & 53900 & 5,26 & 2,10 & 57000 & 91,60 & 0,00 & 15,80 & 68,30 \\
$\mathbf{2 3}$ & Sol & 12,8 & 56200 & 5,38 & 1,44 & 53800 & 92,30 & 15,90 & 15,20 & 78,90 \\
$\mathbf{2 4}$ & Sol & 10,8 & 62800 & 7,55 & 1,75 & 58000 & 93,70 & 18,10 & 16,60 & 63,90 \\
\hline
\end{tabular}


Anexo J - Resultados de temperatura do solo e radiação solar dos sistemas de produção de café orgânico sombreado e a pleno sol

Tabela 1. Resultados de temperatura do solo obtidos no dia 23/09/2003 entre 15:45 e 16:30 no tratamento a pleno sol. Os centímetros citados indicam a profundidade do solo onde a temperatura foi determinada

\begin{tabular}{lllll}
\hline Temperatura Pleno sol & $5 \mathrm{~cm}$ & $10 \mathrm{~cm}$ & $15 \mathrm{~cm}$ & Média Temperatura \\
\hline Norte & 37,6 & 35,4 & 26,1 & 33,03 \\
Sul & 28,5 & 27,0 & 25,0 & 26,83 \\
Leste & 30,8 & 27,3 & 24,9 & 27,66 \\
Oeste & 31,8 & 29,0 & 25,0 & 28,6 \\
\hline
\end{tabular}

Tabela 2. Resultados de temperatura do solo obtidos no dia 23/09/2003 entre 15:45 e 16:30 no tratamento sombreado. Os centímetros citados indicam a profundidade do solo onde a temperatura foi determinada

\begin{tabular}{lllll}
\hline Temperatura Sombreado & $5 \mathrm{~cm}$ & $10 \mathrm{~cm}$ & $15 \mathrm{~cm}$ & Média Temperatura \\
\hline Norte & 26,6 & 24,4 & 23,7 & 24,9 \\
Sul & 18,3 & 17,7 & 17,5 & 17,83 \\
Leste & 20,4 & 19,5 & 19,0 & 19,63 \\
Oeste & 25,4 & 22,9 & 21,3 & 23,2 \\
\hline
\end{tabular}

Tabela 3. Resultados de temperatura do solo obtidos no dia 23/09/2003 entre 15:00 e 16:30 em área sombreada referência. Os centímetros citados indicam a profundidade do solo onde a temperatura foi determinada

\begin{tabular}{lllll}
\hline Referência Sombra & $5 \mathrm{~cm}$ & $10 \mathrm{~cm}$ & $15 \mathrm{~cm}$ & Média Temperatura \\
\hline Norte & 24,0 & 23,1 & 22,2 & 23,1 \\
Sul & 19,6 & 19,3 & 18,9 & 19,26 \\
Leste & 19,7 & 19,3 & 18,8 & 19,26 \\
Oeste & 21,0 & 20,2 & 19,8 & 20,33 \\
\hline
\end{tabular}

Tabela 4. Resultados de temperatura do solo e radiação solar obtidos no dia 24/09/2003 entre 09:15 e 10:00 no tratamento a pleno sol. Os centímetros citados indicam a profundidade do solo onde a temperatura foi determinada

\begin{tabular}{llllll}
\hline Temperatura Pleno sol & $5 \mathrm{~cm}$ & $10 \mathrm{~cm}$ & $15 \mathrm{~cm}$ & Média Temperatura & Radiação solar \\
\hline Norte & 23,1 & 21,2 & 21,0 & 21,76 & 1019 \\
Sul & 23,9 & 21,5 & 20,8 & 22,06 & 1056 \\
Leste & 28,5 & 22,0 & 21,5 & 24,0 & 1085 \\
Oeste & 21,1 & 20,2 & 20,0 & 20,43 & 975 \\
\hline
\end{tabular}


Tabela 5. Resultados de temperatura do solo e radiação solar obtidos no dia 24/09/2003 entre 09:15 e 10:00 no tratamento sombreado. Os centímetros citados indicam a profundidade do solo onde a temperatura foi determinada

\begin{tabular}{llllll}
\hline Temperatura Sombreado & $5 \mathrm{~cm}$ & $10 \mathrm{~cm}$ & $15 \mathrm{~cm}$ & Média Temperatura & Radiação solar \\
\hline Norte & 22,4 & 20,8 & 20,4 & 21,2 & 85 \\
Sul & 18,5 & 17,9 & 17,7 & 18,03 & 96,5 \\
Leste & 21,0 & 19,9 & 19,3 & 20,06 & 135 \\
Oeste & 19,3 & 19,0 & 18,9 & 19,06 & 55 \\
\hline
\end{tabular}

Tabela 6. Resultados de temperatura do solo e radiação solar obtidos no dia 24/09/2003 entre 09:15 e 10:00 em área sombreada referencia. Os centímetros citados indicam a profundidade do solo onde a temperatura foi determinada

\begin{tabular}{llllll}
\hline Referência Sombra & $5 \mathrm{~cm}$ & $10 \mathrm{~cm}$ & $15 \mathrm{~cm}$ & Média Temperatura & Radiação solar \\
\hline Norte & 21,2 & 20,5 & 20,2 & 20,63 & 49 \\
Sul & 20,0 & 18,8 & 18,5 & 19,1 & 35 \\
Leste & 20,5 & 19,2 & 18,7 & 19,46 & 46 \\
Oeste & 18,7 & 18,3 & 18,1 & 18,36 & 41 \\
\hline
\end{tabular}

Tabela 7. Resultados de temperatura do solo e radiação solar obtidos no dia 03/10/2003 entre 12:00 e 12:15 no tratamento a pleno sol. Os centímetros citados indicam a profundidade do solo onde a temperatura foi determinada

\begin{tabular}{llllll}
\hline Temperatura Pleno sol & $5 \mathrm{~cm}$ & $10 \mathrm{~cm}$ & $15 \mathrm{~cm}$ & Média Temperatura. & Radiação solar \\
\hline Norte & 36,0 & 28,5 & 26,5 & 30,33 & 1820 \\
Sul & 30,0 & 24,8 & 23,0 & 25,93 & 1776 \\
Leste & 28,8 & 25,2 & 23,7 & 25,9 & 1625 \\
Oeste & 34,5 & 26,1 & 23,7 & 28,1 & 1770 \\
\hline
\end{tabular}

Tabela 8. Resultados de temperatura do solo e radiação solar obtidos no dia 03/10/2003 entre 12:00 e 12:15 no tratamento sombreado. Os centímetros citados indicam a profundidade do solo onde a temperatura foi determinada

\begin{tabular}{llllll}
\hline Temperatura Sombreado & $5 \mathrm{~cm}$ & $10 \mathrm{~cm}$ & $15 \mathrm{~cm}$ & Média Temperatura. & Radiação solar \\
\hline Norte & 24,8 & 23,1 & 22,2 & 23,36 & 207 \\
Sul & 20,2 & 19,9 & 19,4 & 19,83 & 171 \\
Leste & 21,5 & 20,7 & 19,7 & 20,63 & 140 \\
Oeste & 21,5 & 20,5 & 20,0 & 20,66 & 110 \\
\hline
\end{tabular}

Tabela 9. Resultados de temperatura do solo e radiação solar obtidos no dia 03/10/2003 entre 12:00 e 12:15 em área sombreada de referência. Os centímetros citados indicam a profundidade do solo onde a temperatura foi determinada

\begin{tabular}{llllll}
\hline Referência Sombra & $5 \mathrm{~cm}$ & $10 \mathrm{~cm}$ & $15 \mathrm{~cm}$ & Média Temperatura & Radiação solar \\
\hline Norte & 20,7 & 19,7 & 19,3 & 19,9 & 42 \\
Sul & 20,2 & 19,3 & 18,4 & 19,3 & 80 \\
Leste & 20,5 & 19,8 & 19,0 & 19,76 & 50 \\
Oeste & 20,3 & 19,5 & 18,5 & 19,43 & 102 \\
\hline
\end{tabular}


Anexo K - Resultado das análises relacionadas com a qualidade de café

\begin{tabular}{|c|c|c|c|c|c|}
\hline $\begin{array}{c}\text { Unidade } \\
\text { amostral }\end{array}$ & Bebida & \% Peneira> 14 & Tipo & Rendimento\% & $\begin{array}{c}\text { Defeito } \\
\text { (verde)* }\end{array}$ \\
\hline $1-$ & Dura & 79,7 & $6-10$ & 48,5 & 60 \\
\hline $2-$ & Mole & 80,2 & $5-35$ & 48,5 & 18 \\
\hline $3-$ & Ap.Mole & 82,3 & $6-35$ & 51,2 & 48 \\
\hline $4-$ & Ap.Mole & 84,6 & $6-5$ & 50,0 & 36 \\
\hline $5-$ & Ap.Mole & 88,7 & $5-10$ & 47,8 & 8 \\
\hline $6-$ & Mole & 79,9 & $3-40$ & 46,7 & 3 \\
\hline $7-$ & Ap.Mole & 82,9 & $7-5$ & 52,3 & 99 \\
\hline $8-$ & Dura & 85,4 & $7-5$ & 54,2 & 114 \\
\hline $9-$ & Dura & 88,5 & $5-10$ & 47,5 & 21 \\
\hline $10-$ & Mole & 91,0 & $5-20$ & 46,8 & 5 \\
\hline $11-$ & Mole & 88,9 & $4 / 5$ & 43,8 & 0 \\
\hline $12-$ & Dura & 87,5 & $3 / 4$ & 43,0 & 3 \\
\hline $13-$ & Dura & 85,1 & 5 & 51,5 & 7 \\
\hline $14-$ & Mole & 79,6 & $4-20$ & 48,8 & 6 \\
\hline $15-$ & AP.Mole & 88,0 & 6 & 50,8 & 48 \\
\hline $16-$ & Ap.Mole & 85,0 & $5-5$ & 51,0 & 12 \\
\hline $17-$ & Dura & 88,8 & $5-35$ & 51,0 & 48 \\
\hline $18-$ & Ap.Mole & 87,6 & $6-10$ & 54,5 & 57 \\
\hline $19-$ & Dura & 85,4 & $6-35$ & 52,0 & 84 \\
\hline $20-$ & Ap.Mole & 74,4 & $6-15$ & 50,5 & 42 \\
\hline $21-$ & Dura & 81,9 & $5-45$ & 50,7 & 36 \\
\hline $22-$ & Dura & 86,1 & $5-30$ & 54,7 & 15 \\
\hline $23-$ & Dura & 80,7 & $7-20$ & 57,0 & 144 \\
\hline $24-$ & Dura & 79,9 & $6-30$ & 51,3 & 72 \\
\hline
\end{tabular}

*Número de grãos em amostra de 300 g. 


\section{REFERÊNCIAS BIBLIOGRÁFICAS}

ADUAYI, E. A. Soil-plant nutrient relationships in tree crops with special reference to coffee: A review. Turrialba, v.20, n.4, p.463-470, 1970.

AGENCY FOR TOXIC SUBSTANCES AND DISEASE REGISTRY . ToxFAQs: hazardous substance fact sheets. http://atsdr1.atsdr.cdc.gov/toxfaq.html: ATSDR, 2001. (10 fev. 2002).

AGRIOS,G.N. Plant Pathology. Orlando FL: Academic Press, 1982. 633p.

ALFASSI, Z.B. Activation analysis. Florida: CRC Press, 1990. v.1, 172p.

ALTIERI, M.A. The ecological role of biodiversity in agroecosystems. Agriculture Ecosystems \& Environment, v.74; p. 19-31, 1999.

ALTIERI, M. Agroecologia: A dinâmica produtiva da agricultura sustentável. 3. ed., Porto Alegre RS: Ed. Universidade/UFRGS, 2001. 110p.

ALVARENGA, M.I.N.; GUIMARÃES, P.T.G. Circular Técnica: Arborização como componente da sustentabilidade da lavoura cafeeira. Lavras: - Empresa de Pesquisa Agropecuária de Minas Gerais - EPAMIG. n.80, mês abril, 1998.

AMBrosano, E.J; CERVEIRA, R.; MURAOKA, T. Curso regional de agricultura orgânica: dia de campo. 1 ed.. Piracicaba: Degaspari, 2000. 168p. 
ASSOCIAÇÃO BRASILEIRA DA INDÚSTRIA DE CAFÉ. Estatísticas. http://abic.com.br/estatistica/index.html, 2001. (15 jun 2002)

BACCHI, M.A.; FERNANDES, E.A.N.; OLIVEIRA, H. A. Brazilian experience on $\mathrm{k}_{0}$ standardized neutron activation analysis. Journal of Radioanalytical and Nuclear Chemistry, v.245, n.1, p.217-222, 2000.

BACCHI, M.A; FERNANDES, E.A.N; "Quantu - design and development of a software package dedicated to $\mathrm{k}_{0}$-standardized INAA”. Journal of Radioanalytical and Nuclear Chemistry, 2001. /no prelo/

BARRADAS, V.L.; FANJUL,L. La importância de la cobertura arbórea en la temperatura del agroecosistema cafetalero. Biótica, v.09, n. 04, p. 415-421, 1984.

BEER, J.; MUSCHLER,R.; KASS, D.; SOMARRIBA,M. Shade management in coffee and cacao plantation. Agroforestry Systems, v.5, p. 3-13, 1987.

BEER, J. Advantages, disavantages and desirable characteristics of shade trees for coffee, cacao and tea. Agroforestry Systems, v.38, p. 139-164, 1998.

BENCKISER, G. Fauna in Soil Ecossystems: Recycling Processes, Nutrient Fluxes and Agricultural Production. 1 ed.. New York: Marcel Dekker Press, 1997. 414p.

BERGAMIN,J. As chuvas e a broca do café. Boletim da Superintendência dos Serviços do café (Brasil) v.41, n. 232, p. 282-283, 1946.

BLAINE, M.F. Soil Microbial Ecology: Applications in agricultural and environmental management. 2 ed.. New York: Marcel Dekker Press, 1992. 646p. 
BODE, P.; FERNANDES, E.A.N.; GREENBERG, R.R. Metrology for chemical measurements and the position of INAA. Journal of Radioanalytical and Nuclear Chemistry, v. 245, n.1, p. 109-114, 2000.

BOUWMAN, A.F.; HOEK, K.W. van der. Scenarios of animal waste production and fertilizer use and associated ammonia emission for the developing countries. Atomspheric Environment, v.31, n.24, p. 4095-4102, 1997.

BRADY, N. C. Natureza e propriedades dos solos. Trad. Antônio B. Neiva Figueiredo Filho. 7. Ed.. Rio de Janeiro: Freitas Bastos, 1989. 898 p.

BRIDGES, E.M. World Soils. 2 Ed.. Cambridge: Cambridge University Press, 1978. 128 p.

BUDOWSKI, G.; RUSSO, R. Nitrogen-fixing trees and nitrogen fixation in sustainable agriculture: Research challenges. Soil Biology Biochemistry, v.29, n. 5/6, p. 767-770, 1997.

CAMARGO, A.P.; SANTINATO, R. Efeito de concorrência de diferentes espécies arbóreas e arbustivas como quebra-vento, na formação do cafezal - Parte II. In: CONGRESSO BRASILEIRO DE PESQUISAS CAFEEIRAS, 15, 1989. Maringá-PR. Anais Eletrônicos.Maringá-PR, 1989. Disponível em CD Rom. Windows 95.

CAMARGO, A.P; CAMARGO, M.B.P. Definição e esquematização das fases fenológicas do cafeeiro arábica nas condições tropicais do Brasil. Bragantia, v.60, n.1, 2001.

CAMARGO, F.A.; SANTOS, G.A. Fundamentos da Matéria Orgânica do Solo. 1.ed. Porto Alegre: Genesis, 1999. 508p.

CAMPBELL, C.A.; BIEDERBECK, V.O.; ZENTENER, R.P.; LAFOND, G.P. Effect of crop rotations and cultural practices on soil organic matter, microbial biomass and respiration in a thin Black Chernozem. Canadian Journal of Soil Science, v.71, p.363376, 1991. 
CARTER, M.R.; RENNIE, D.A. Changes in soil quality under no-tillage farming systems: distribution of microbial biomass and mineralizable $\mathrm{C}$ and $\mathrm{N}$ potential. Canadian Journal of Soil Science, v.62, p. 587-597, 1982.

CARVALHO, G.R.; TAYRA, F. Foreign Sales take off. Gazeta Mercantil, International Special Edition - Coffee, Sao Paulo, 13/out/2001. p.11

CARVALHO, F.V. Horticultura orgânica. In: CONGRESSO BRASILEIRO DE HORTICULTURA ORGÂNICA, NATURAL, ECOLÓGICA E BIODINÂMICA, 1., Piracicaba, 2001. Resumos. Piracicaba, 2001.

CHABOUSSOU, F. Plantas doentes pelo uso de agrotóxicos: a teoria da trofobiose. 2 ed. Porto Alegre: L\&PM, 1987. 256p.

CHAMBERS,J.C.; BLANK,R.R.;ZAMUDIO,D.C.; TAUCH,R.J. Central Nevada riparian areas: physical and chemical properties of meadow soils. Journal of Range Management, v.52, n.01, 1999.

CHRISTENSEN, B.T.; JOHNSTON, A.E. Soil organic matter and soil quality- lessons learned from long-term field experiments at Askov and Rothamsted. In: Gregorich. , E.G., Carter, M.R. (Eds.). Soil Quality for crop Production and Ecosystem Health: Developments in Soil Science, v.25.Amsterdan: Elsevier, 1997. p.399-430.

CLAUDINO, M. Plantas de cobertura de solo. Chapecó: Ed. do Autor, 1991. 337p.

CLARKE, R.J.; MACRAE, R. Coffee Chemistry. Barking: Elsevier, 1985a. p.306.

CLARKE, R.J.; MACRAE, R. Coffee Agronomy. Barking: Elsevier, 1985b. p.334. 
COELHO, M.J.H. Café do Brazil: o sabor amargo da crise. Florianópolis: Oxfam, 2002. $58 \mathrm{p}$.

COMPANHIA NACIONAL DE ABASTECIMENTO / MINISTÉRIO DA AGRICULTURA. Safra Café. http://www.conab.gov.br/politica_agricola/SafraCafe/SafraCafe.pdf CONAB, 2002 (10 jun. 2002)

COMPANHIA NACIONAL DE ABASTECIMENTO / MINISTÉRIO DA $\begin{array}{lllll}\text { AGRICULTURA } & - & \text { CONAB. } & \text { Safra } & \text { Café. }\end{array}$ http://www.conab.gov.br/politica_agricola/SafraCafe/SafraCafe.pdf CONAB, 2003 (15 set. 2003)

CONSELHO DOS EXPORTADORES DE CAFÉ DO BRASIL - CECAFE. Dados estatísticos. http://www.cecafe.com.br/dadosestatisticos/exportacao/2002 CECAFE, 2002 (05 mai. 2003)

CONSELHO INTERNACIONAL DO CAFÉ. Análise agroeconômica do café cultivado organicamente ou café “orgânico”. Londres: Junta Executiva, 1997. 19p. (Apostila).

COSTA, A.N.; PREZOTTI, L.C. Uso do DRIS na avaliação do estado nutricional do café arábica na região serrana do estado do Espírito Santo. In: $23^{\circ}$ Congresso Brasileiro de Pesquisas Cafeeiras, Manhuaçu, 1997. Resumos. Manhuçu, 1997. p. 190-191.

COSTA FREITAS, A.M.; MOSCA, A.I. Coffee geographic origin - an aid to coffee differentiation. Food Research International, v.32, p.565-573, 1999.

COSTA, M.B.B.; CAMPANHOLA, C. A agricultura alternativa no Estado de São Paulo. 1. ed. Jaguariúna: Embrapa-CNPMA,1997. 63p. 
COYNER,M.S. Agriculture and trade in Nicarágua Washington DC, Foreign Agriculture Service, 1960.

DEANS, J.D.; DIAGNE, O.; LINDLEY,D.K.;DIONE,M.; PARKINSON,A.A. Nutrient and organic matter accumulation in Acaca senegal fallows over 18 years. Forest Ecology and Management, v.124, p. 2-3, 1999.

DE SOETE, D.; GIJBELS, R.; HOSTE, J. Neutron activation analysis. London: Wiley \& Sons, 1972. 836p.

DORAN, J.W.; COLEMAN, D.C.; BEZDICEK, D.F.; STEWART, B.A. (Eds.), Defining Soil Quality for a Sustainable Environment. SSSA Special Publication n. 35, 1994.

DORAN, J.W.; ZEISS,M.R. Soil health and sustainability: managing the biotic component of soil quality. Applied Soil Ecology, v.15, p.3-11, 2000.

DUXBURY, J.M.; SMITH, M.S.; DORAN, J.W. Soil organic matter as a source and sink of plant nutrients. In COLEMAN, D.C.; OADES, J.M.; and UEHARA, G. (eds) Dynamics of Soil Organic Matter in Tropical Ecosystems. Honolulu, Hawaii, USA: University of Hawaii Press, 1989, 249p.

EHLERS, E. Agricultura sustentável - Origens e perspectivas de um novo paradigma. 1 ed. São Paulo: Livros da Terra. 1996, 178p.

ELPO, E.R.S.; FREITAS, R.J.S. Avaliação dos teores de cádmio, chumbo, cromo e níquel nos alimentos da cesta básica. Boletim do Centro de Pesquisa e Processamento de Alimentos, v.13, n.2, p. 71-84, 1995.

ELWALI, A.M.; GASCHO, G.J. Soil testing, foliar analysis, and DRIS as a guide for sugarcane fertilization. Agronomy Journal, v.76, p.466-470, 1984. 
FADINI, M.A.M.; LOUZADA, J.N.C. Impactos ambientais da agricultura convencional. Produção integrada de frutas - Informe agropecuário. Belo Horizonte.v. 22, n.213, p. 24-29, nov.-dez. 2001.

FAVERO, C.; JUCKSCH, I.; COSTA, L. M.; ALVARENGA, R. C.; NEVES, J.C.L.

Crescimento e acúmulo de nutrientes por plantas espontâneas e por leguminosas utilizadas para adubação verde. Revista Brasileira de Ciência do Solo, v. 24, n. 1, p. 171-177, jan./mar. 2000.

FEDERAÇÃO DA AGRICULTURA E PECUÁRIA DO ESTADO DE MINAS GERAIS FAEMG. Agronegócio Café. http://www.faemg.org.br FAEMG, 2001, 2002 (10 jul. 2003)

FERNANDES, D.R. Manejo do Cafezal. In: RENA, A.B. et al (ed) Cultura do Cafeeiro. Piracicaba: Associação Brasileira para a Pesquisa de Potassa e do Fosfato, 1986. p. 275301.

FERNANDES, E.A.N.; TAGLIAFERRO, F.S.; BODE, P.; MOREIRA, C.F. Safety and nutritional challenges of sustainable organic coffee. In: International Congress of Nutrition, 17, Vienna, August 27-30, 2001. Institute of Nutritional Sciences/IAEA.

FERNANDES, L.A.; SIQUEIRA, J.O.; GUEDES, G.A. de A., CURI, N. Propriedades químicas e bioquímicas de solos sob vegetação de mata e campo cerrado adjacentes. Ciência e Agrotecnologia, Lavras, v.21, n.1, p.58-70, 1978.

FISHER, R.F. Amelioration of degraded rain Forest soils by plantations of native trees. Soil Science Society of America Journal, v.59, p. 544-549, 1995.

FOLLET, R.F.; SCHIMEL, D.S. Effect of tillage practices on microbial biomass dynamics. Soil Science Society of America Journal, v.53, p.1091-1096, 1989. 
FOOD AND AGRICULTURE ORGANIZATION OF THE UNITED STATES. http:// apps.fao.org: FAO, 2001.

FRANÇA, E.J.; BACCHI, M.A.; FERNANDES, E.A.N.; GANDOLFI. S. Mata de Santa Genebra, SP, Brazil: Can mineral cycling in urban forestry fragement reveal anthropogenic activities? IAEA-TECDOC-1388 - Biomonitoring of atmospheric pollution (with emphasis on trace elements) - BioMAP II, p. 308-316, 2003.

FRANÇA, E.J.; FERNANDES, E.A.N.; BACCHI, M.A. Ni-Cr alloy as neutron flux monitor: composition and homogeneity assessment by INAA. Journal of Radioanalytical and Nuclear Chemistry, v.257, p.113-115, 2003.

FREITAS, R.B. Avaliações fisológicas de cafeeiros (Coffea arabica L.) e seringueiras (Hevea brasiliensis Muell Arg.) em diferentes sistemas de cultivos. Lavras - MG: 2000. 57p. Dissertação - Mestrado UFLA.

FREITAS, Z.M.T.S.; ARAÚJO, J.B.S.; WISNER, L.A.; HURTADO, S.C.; SILVA, R.F.Interferência do Ipê amarelo (Tabebuia serratifolia) na qualidade dos grãos de café, tamanho e tipo, da variedade Icatu. In: CONGRESSO BRASILEIRO DE PESQUISAS CAFEEIRAS, 28., Caxambu, 2002. Resumos. Caxambu, 2002.

GARCIA, M.A. : Ecologia aplicada a agrossistemas como base para a sustentabilidade. Produção integrada de frutas - Informe agropecuário. Belo Horizonte.v.22, n.213, p.30-38, nov.-dez., 2001.

GLIESSMAN, S. R. Agroecologia: processos ecológicos em agricultura sustentável. 2. ed. Porto Alegre: Ed. Universidade- UFRGS, 2001. 384p.

GLOVER, J.D.; REGANOLD, J.P.; ANDREWS, P.K. Systematic method for rating soil quality of convencional, organic, and integrated apple orchards in Washington State. Agriculture, Ecosystems and Environmetal, v.80, p.29-45, 2000. 
GOBBI, J.A. Is biodiversity-friendly coffe financially viable? Na analisys of five different coffee production systems In western El Salvador. Ecological Economics, v.33, p.267$281,2000$.

GRANER, E.A. \& GODOY JÚNIOR, E.C. Culturas da fazenda brasileira. São Paulo: Melhoramentos, 1964. 461p.

GREENBERG, R.R.; BODE, P.; LINDSTROM, R.M.; FERNANDES, E.A.N. "Instrumental Neutron Activation Analysis for Trace Elements in Solid Materials," Consultive Committee on the Quality of Materials (CCQM), Sèvres, France, April 4, 2000.

GROSSMAN, J.M. Exploring farmer knowledge of soil process in organic coffee systems of Chiapas, Mexico. Geoderma, v.111, p.267-287, 2003.

HANSEN, B.; ALROE, H.F.; KRISTENSEN, E.S. Approaches to assess the environmental impact of organic farming with particular regard to Denmark. Agriculture, Ecosystems and Environmetal, v.83, p.11-26, 2001.

HARADA, D.Y. Selo único ou biodiversidade na certificação. In: CONGRESSO BRASILEIRO DE HORTICULTURA ORGÂNICA, NATURAL, ECOLÓGICA E BIODINÂMICA, 1., Piracicaba, 2001. Resumos. Piracicaba, 2001.

HARCOMBE, R. Soil nutrient loss as a factor in early tropical secondary sucession. Biotropica, v.12, p.8-15, 1980.

HARKALY, A. Presente e futuro das certificadoras no Brasil. In: CONGRESSO BRASILEIRO DE HORTICULTURA ORGÂNICA, NATURAL, ECOLÓGICA E BIODINÂMICA, 1., Piracicaba, 2001. Resumos. Piracicaba, 2001. 
HASHIZUME, H.; MATIELlO, J.B.; BRANDÃO, J.E.. Comportamento de cafezal arborizado com bananeira na zona alta do estado do Espírito Santo. In: CONGRESSO BRASILEIRO DE PESQUISAS CAFEEIRAS, 8., Campos do Jordão, 1980. Resumos. Campos do Jordão, 1980.

HENDRIX, P.F.; CROSSLEY, D.A. Jr.; BLAIR, J.M.; COLEMAN, D.C. Soil biota as components of sustainable agroecosystems. In: EDWARDS, C.A.; LAL, R, MADDEN, P, MILlER, R. ( Eds. ), Sustainable Agricultural Systems. Soil and Water Conservation Society, CRC Press, 1990. p. 637- 654.

HOSTE, J.; DE BEEK, J.O.; GIJBELS, R. et al. Instrumental and radiochemical activation analysis. London: Butterworths, 1971. 148p.

IFOAM, International Federation of Organic Agriculture Movements, The world of organic agriculture $\mathbf{2 0 0 3}$ - statistics and future prospects. Disponível em: < http://www.ifoam.org/statistic/statistics studie.pdf. 2003.

IFOAM. Engenharia Genética versus Agricultura Orgânica. Theley, 2003. 10p.

JORDAN, C.F. Nutrient cycling in tropical forest ecosystems. Chichester: John Wiley, 1985. 200p.

KARLEN, D.L.; MAUSBACH, M.J.; DORAN, J.W.; CLINE，R.G.; HARRIS，R.F.; SCUMAN, G.E. Soil quality: a concept, definition and framework for evaluation. ( A guest editorial ). Soil Science Society of America Journal, v.61, p.4-10, 1997.

KIEHL, E. J. Fertilizantes Orgânicos. Piracicaba: Agronômica Ceres, 1985.492 p.

KRIVAN, V.; BARTH, P.; MORALES, A.F. Multielement analysis of green coffee and its possible use for determination of origin. Mikrochimica Acta, v.110, p.217-236, 1993. 
KRUG, F.J. Pré-tratamento de amostras. In: WORKSHOP ON METHODS OF SAMPLE DECOMPOSITION, 1., 1996, Piracicaba. Anais. Piracicaba: CENA-USP, 1996. 106p.

KUMAR, D. \& TIESZEN, L.L. Some aspects of photosysthesis and related processes in Coffea arabica L. Kenya Coffee, Nairobi, v.41, p301-306, 1976.

LOPES, A.S.; CARVALHO, J.G. Técnicas de levantamento e diagnose da fertilidade do solo. In: OLIVEIRA, A.J.; GARRIDO, W.E.; ARAÚJO, J.P.; LOURENÇO, S. (Coord.), Métodos de pesquisa em fertilidade do solo, Brasília: EMBRAPA, 1991. p.7-61.

LOPES, E. S.; TOLEDO, S, v.; HIROGE, R.; DIAS, R.; OLIVEIRA, E. Efeito do fungo micorrízico Gigaspora margarita no desenvolvimento e aproveitamento de fósforo e de zinco em mudas de cafeeiro "Mundo Novo" em casa-de-vegetação. In: CONGRESSO BRASILEIRO DE PESQUISA CAFEEIRA, 10., 1983, Poços de Caldas-MG. Anais. Poços de Caldas, 1983.

LORENZI, H. Manual de identificação e controle de plantas daninhas. Nova Odessa: Ed. Plantarum, 1994. 299p.

LORENZI, H. Árvores brasileiras: manual de identificação de plantas arbóreas nativas do Brasil. Nova Odessa: Ed. Plantarum, p.222, 1998.

MALAVOLTA, E.; HAAG, H.P.; MELLO, F.A.F.; BRASIL SOBR ${ }^{0}$, M.O.C. Nutrição mineral e adubação de plantas cultivadas. São Paulo: Pioneira, 1974. 752p.

MALAVOLTA, E. Nutrição, adubação e calagem para o cafeeiro. In: RENA, A.B. et al (ed) Cultura do Cafeeiro. Piracicaba-SP: Associação Brasileira para a Pesquisa de Potassa e do Fosfato, 1986. p. 165-274. 
MALAVOLTA, E.; VITTI, G.C.; OLIVEIRA, S.A. Avaliação do estado nutricional das plantas. Piracicaba: Associação Brasileira para a Pesquisa de Potassa e do Fosfato, 1989. 201p.

MARSCHNER, H. Mineral nutrition of higher plants. New York: Academic Press, 1995. $997 \mathrm{p}$.

MARKERT, B. Distribution and biogeochemistry of inorganic chemicals in the environment. In: SHUURMANN, G.; MARKERT, B. Ecotoxicology. Amsterdan: John Wiley \& Sons, 1998. p.165-222.

MARTIN, M.J.; PABLOS, F.; GONZALES, A.G. Application of pattern recognition to the discrimination of roasted coffees. Analytica Chimica Acta, v.320, p.191-197, 1996.

MARTIN, M.J.; PABLOS, F.; GONZALES, A.G. Discrimination betweem arabica and robusta green coffee varieties according to their composition. Talanta, v.46, p.12591264, 1998a.

MARTIN, M.J.; PABLOS, F.; GONZALES, A.G. Characterization of gren coffee varieties according to their metal component. Analytica Chimica Acta, v.358, p.177-183, 1998b.

MARTIN, M.J.; PABLOS, F.; GONZALES, A.G. Characterization of arabica and robusta roasted coffee varieties and mixture resolution according to their metal content. Food Chemistry, v.66, p.365-370, 1999.

MARTINEZ, H. E. P.; CARVALHO, J. G.; SOUZA, R. B. Diagnose foliar. In: RIBEIRO, A. C.; GUIMARÃES, P. T. G.; ALVAREZ V. , V. H. (Ed.). Recomendações para o uso de corretivos e fertilizantes em Minas Gerais: $5^{\text {a }}$ aproximação. ViçosaMG, 1999. p. 143-168. 
MARTINS, M. Caracterização de sistemas orgânicos de produção de café utilizados por agricultores familiares em Poço Fundo/MG. Lavras, 2003. 190p. Dissertação (Doutorado) - Universidade Federal de Lavras.

MATIEllo, J.B. Sistemas de Produção na Cafeicultura Moderna, Tecnologias de plantio adensado, renque mecanizado, arborização e recuperação de cafezais. 1 ed.. Rio de Janeiro: MM Produções Gráficas, 1995.102p.

MATIELLO, J.B; SANTINATO, R.; GARCIA, A.W.R.; ALMEIDA, S.R.; FERNANDES, D.R. Cultura de café no Brasil: novo manual de recomendações. Rio de Janeiro: MAPA/PROCAFÉ, 2002. 387p.

MENDES, A.N.G.; ABRAHÃO, E.J.; CAMBRAIA, J.F.; GUIMARÃES, R.J. Recomendações técnicas para a cultura do cafeeiro no sul de Minas Gerais, Lavras: UFLA, 1995, 76p.

MILLS, H.A.; JONES, J.B. Plant analysis handbook II: a practical sampling, preparation, analysis and interpretation guide. MicroMacro Publishing, Inc., 1997. 422p.

MIRANDA, G.M.; PEREIRA, R.C.A.; BERGO, C.L. Comportamento de seis linhagens de café (Coffea arábica) em condições de sombreamento e a pleno sol no estado do Acre, Brasil. Ciência e Agrotecnologia, Lavras, v. 23, n.1, p.62-69, jan/mar 1999.

MIYASAWA , M.; PAVAN, M.A.; BLOCH, M.F.M. Avaliação de métodos com e sem digestão para extração de elementos em tecidos de plantas. Ciência e Cultura, v.36, p. 1953-1958, 1984.

MIYASAWA , M.; PAVAN, M.A.; BLOCH, M.F.M. Análise química de tecido vegetal. Londrina: IAPAR, 1992. 17p. 
MOREIRA, C. F.; MANOEL, R.M.; SEGGES, J.H.; FERNANDES, E.A.N. Avaliação da qualidade do café orgânico produzido sob sombra frente a café orgânico produzido a pleno sol. In: CONGRESSO BRASILEIRO DE PESQUISAS CAFEEIRAS, 28., Caxambu, 2002. Resumos. Caxambu, 2002.

MOREIRA, C.F; FERNANDES, E.A.D; TAGLIAFERRO, F.S. Discriminação de café orgânico produzido sob sombra e a pleno sol pela composição química elementar. In: Congresso Brasileiro de Metrologia, 3, Recife, 2003. Artigos. São Paulo: O2 Estúdio Web / Metrologia \& Instrumentação, 2003

MORGANO, M.A.; PAULUCI, L.F.; MANTONANI, B.D.M.; MORY, E.E.M. Determinação de minerais em café cru. Ciência e Tecnologia de Alimentos, v.22, n.1, 2002.

MUSCHLER, R.G.; BONNEMANN, A.; Potentials and limitations of agroforestry for changing land-use in the tropics: experiences from Central America. Forest Ecology. and Managent, v.91, p.61-73, 1997.

NAIDU, G.R.K.; DENSCHLAG, H.O.; MAUERHOFER, E.; PORTE, N.; BALAJI, T. Determination of macro, micro nutrient and trace element concentrations in Indian medicinal and vegetable leaves using instrumental neutron activation analysis. Applied Radiation and Isotopes, v.50, p.947-953, 1999.

NUNES, M.A.; DIAS, M.A.; RAMALHO, J.D.C.; DIAS, M.A. Effect of nitrogen supply on the photosynthetic performance of leaves from coffee plants exposed to bright light. Journal of Experimental Botany, v. 44, n. 262, p. 893-899, 1993.

NUTMAN, F.J. Studies of the physiology of Coffea arabica. I Phtotosyntesis of coffee leaves under natural conditions. Annals of Botany, v.1, p. 353-367, 1937. 
OLIVEIRA, H.; FERNANDES, E.A.N.; FERRAZ, E.S.B. Determination of trace elements in tree rings of Pinus by neutron activation analysis. Journal of Radioanalytical and Nuclear Chemistry, v.217, n.1, p.125-129, 1997.

OLIVEIRA, J.J.V. Interface entre contaminantes em alimentos: resíduos de pesticidas, micotoxinas, metais pesados e drogas veterinárias. In: SEMINÁRIO SOBRE CONTAMINANTES EM ALIMENTOS, Campinas, 1997. Contaminantes em alimentos. Campinas: ITAL, 1997. p.1-10.

ORGAniZAÇÃO INTERnACIONAL DO CAFÉ - OIC. The Global Coffee Crisis. http://www.ico.org/ed/crisis.pdf. OIC, 2002. (10 ago 2002)

ORLANDO FILHO, J.E.; ZAMBELLO JR., E. Diagnose foliar. In: Nutrição e adubação da cana-de-ácucar no Brasil. Instituto do açúcar e do álcool. Piracicaba, Planalsucar. p.125-152, 1983.

PASCHOAL, A. D. Produção orgânica de alimentos: agricultura sustentável para os séculos XX e XXI. Piracicaba: ESALQ, 1994, 191p.

PEDINI, S. A produção de café orgânico. I Workshop Sistemas Agroflorestais para o Cultivo do Café. Machado. p.11-12, 2000.

PENTEADO, S. R. Introdução à Agricultura Orgânica - Normas e Técnicas de Cultivo. Campinas: Ed. Grafimagem. 2000, 110p.

PEREIRA, R.G.F.A. Qualidade do café. Informativo Técnico -Universidade Federal de Lavras. n. 01, mês junho, 1999.

PERFECTO, I.; VANDERMEER, J.; HANSON, P.; CARTIN, V. Shade coffee: a disappearing refuge for biodiversity. Bioscience, v. 46, n.8, p.598-608, 1996. 
PRIMAVESI, A. Manejo ecológico do solo: a agricultura em regiões tropicais. 9.ed. São Paulo: Ed. Nobel, 1990. 549p.

PRITCHETT, W.L.; FISHER, R.F. Properties and management of Forest soils. Chichester: John Wiley and Sons, 1987. 512p.

RAIJ, B.van; QUAGGIO, O.C. Métodos de análise de solo para fins de fertilidade. Campinas: Instituto Agronômico, 1983. 31p.

RAIJ, B.van. Fertilidade do solo e adubação. Piracicaba: Ceres, Associação Brasileira para a Pesquisa de Potassa e do Fosfato, 1991. 343p.

RAIJ, B.van.; CANTARELLA, H.; QUAGGIO, J.A. et al. Recomendações de adubação e calagem para o Estado de São Paulo. Campinas: IAC, 1997. 185p.

REGANOLD,J.P. Sustainable agriculture. Scientific American. June, 1990.

RENA, A.B.; MAESTRI, M. Fisiologia do cafeeiro. In: RENA, A.B. et al (ed) Cultura do Cafeeiro. Piracicaba-SP: : Associação Brasileira para a Pesquisa de Potassa e do Fosfato, 1986. p. 13-85.

RENA, A.B.; MALAVOLTA, E.; ROCHA, M.; YAMADA, T. Cultura do cafeeiro: fatores que afetam a produtividade. Piracicaba: Associação Brasileira para pesquisa da potassa e do fosfato, $1986.447 \mathrm{p}$.

RICE, R.A. La situacion del café orgânico certificado en el mundo. Agricultura Orgánica, v. 4, p.18-20, 1998.

RICCI, M.S.F; MANOEL, R.M; SEGGES, J.H; OLIVEIRA, F.F; MIRANDA, S.C; Influência da arborização no crescimento, estado nutricional, produtividade e qualidade de bebida de 
café conilon (Coffea canephora) sob manejo orgânico. In: CONGRESSO BRASILEIRO DE PESQUISAS CAFEEIRAS, 28., Caxambu, 2002. Resumos. Caxambu, 2002.

ROCHA, M.T. Fertilização Orgânica e Qualidade do Solo. Piracicaba, 2000. 65p. Dissertação (Mestrado), Escola Superior de Agronomia "Luis de Queiroz" Universidade de São Paulo - , Piracicaba.

RODRIGUES, V.G.S.et al. Arborização em Lavouras de Café - Experiências de Agricultores em Rondônia-Brasil. In: SIMPÓSIO DE PESQUISA DOS CAFÉS DO BRASIL, 2. 2001. Vitória-ES. Anais Eletrônicos. Vitória: ES, 2001. Disponível em CD Rom. Windows 95.

ROMERO, J.P.; ROMERO, J.C.P. Cafeicultura Prática: cronologia das publicações e dos fatos relevantes. São Paulo: Ceres, 1997 400p.

RUFINO, J.L. Por um planejamento estratégico para o café. Revista SEBRAE, n.09, p.8695, 2003.

SAES, M.S.M.; SOUZA, M.C.M.; OTANI, M.N. Actions to promote sustainable development: the case of Baturité shaded coffee, state of Ceará, Brazil. 2001 www.fao.org/regional/lamerica/prior/desrural/alianzas/pdf/norico.pdf

SAIKI, M.; CHAPARRO, C.G.; VASCONCELOS, M.B.A.; MARCELLI, M.P. Determination of trace elements in lichens by instrumental neutron activation analysis. Journal of Radioanalytical and Nuclear Chemistry, v.217, n.1, p.111-115, 1997.

SANCHEZ, P.A.; PALM, C.A.; SZOTT, L.T., CUEVAS, E. And LAL, R. Organic input management in tropical agroecosystems. In: COLEMAN, D.C., OADES, J.M. and UEHARA, G. (eds) Dynamics of Soil Organic Matter in Tropical Ecosystems. Honolulu-Hawaii, USA: University of Hawaii Press, 1989. 249p. 
SANCHEZ, P.A. Deforestation reduction initiative: An imperative for world sustainability in the twenty-first century. In: BOUWNAN, A.E. (eds) Soils and the Greenhouse Effect. New York: John Wiley, 1990. 596p.

SANTANA, L.A.R. \& FARÁ, F. T. Produção de Café - Impacto Ambiental. In: ZAMBOLIN, L. Café Produtividade, Qualidade e Sustentabilidade. Viçosa-MG: Editora, 2000. p. 381.

SANTINATO, R.; AGUIAR, S.; FERNANDES, A.L.T.; ALVARENGA, M.; FIGUEIREDO, E.M.FIGUEIREDO, E.M. Estudo da arborização com Grevílea na cafeicultura do oeste da Bahia. In: CONGRESSO BRASILEIRO DE PESQUISAS CAFEEIRAS, 28., Caxambu, 2002. Resumos. Caxambu, 2002.

SARRUGE, J.R.; HAAG, H.P. Análises químicas em plantas. Piracicaba: ESALQ, 1974. $56 \mathrm{p}$.

SAS INSTITUTE INC. SAS/STAT Guide for personal computers. 6 ed. Cary: SAS Institute, 1996. 1028p.

SECRETARIA DE COMÉRCIO EXTERIOR - SECEX. Balança comercial brasileira Novembro/2002. Brasília: Ministério da Indústria, do Comércio e do Turismo. Brasil, 2002.

SEGGES, J. H. Focalizando o Café e a Qualidade. Seropédica, RJ: Editora Universidade Rural, 2001. 125p.

SERRANO, O, v. Manejo orgânico do solo e nutrição vegetal. In: SEMINÁRIO DE AGRICULTURA ORGÂNICA, 1, Bragança Paulista, 1998, p.10-47.

SILVA, E.B.; NOGUEIRA, F.D.; GUIMARÃES, P.T.G. Qualidade de grãos de café beneficiados em resposta àadubação potássica. Scientia Agrícola, v.59, n.1, 2002. 
SILVA, F.C. Manual de Análises Químicas de Solos, Plantas e Fertilizantes. Brasília: Empresa Brasileira de Pesquisa Agropecuária, 1999. 370p.

SILVA FILHO, G. N.; VIDOR, C. Atividade de microorganismos solubilizadores de fosfatos na presença de nitrogênio, ferro, cálcio e potássio. Pesquisa Agropecuária Brasileira, v. 36, n. 12, p.1495-1508, 2001.

SINDICATO NACIONAL DA INDÚSTRIA DE PRODUTOS PARA DEFESA AGRÍCOLA - SINDAG. Vendas de defensivos agrícolas por culturas de destinação e classes - 1997/2000. http://www.sindag.com.br/vendasdedefensivosporculturas/2003 SINDAG, 2003 (05 fev 2003)

SINGH, J.S.; RAGHUBANSHI, A.S.; SINGH, R.S.; SRIVASTAVA, S.C. Microbial biomass acts as a source of plant nutrients in dry tropical forest and savanna. Nature, v.338, n.6215, p. 499-500, 1989.

SOTO-PINTO, L.; PERFECTO, I.; HERNANDEZ, J.C.; NIETO, J.C. Shade effect on coffee production at the northern Tzeltal zone of the state of Chiapas, Mexico. Agriculture, Ecosystems and Environmetal, v.80, p.61-69, 2000.

SOUZA, M.C.M; SAES, M.S.M. A qualidade no segmento de cafés especiais. Informativo Garcafé, Garça, ago. 2001.

SOUZA, N.L. Comportamento fisiológico de cultivares de Coffea arábica L. submetidos a diferentes níveis de radiação solar. Lavras, 2001. 41p. Dissertação (Mestrado) Universidade Federal de Lavras.

SRIVASTAVA, S.C.; SINGH, J.S. Effect of cultivation on microbial carbon and nitrogen in dry tropical forest soil. Biology and Fertility of Soils, v.8, p.343-48, 1989. 
SWART, R.J. Nitrous oxide emission from grasslands on sand, clay and peat soils in the Netherlands. In: VELTHOF, G.L; OENEMA, O.; HAM, J. Van.; JANSSEN, L.J.H.M. (eds.) Non- $\mathrm{CO}_{2}$ greenhouse gases: Why and how to control? Dordrecht: Kluwer Academic Publishers, 1994. p.439-444

TAGLIAFERRO, F.S.; FERNANDES, E.A.N. Avanços da metrologia em química em estudos de elementos tóxicos em café brasileiro. In: II CONGRESSO SULAMERICANO DE METrologia,2, Foz do Iguaçu, 1999. Proceedings. Foz do Iguaçu: Sociedade Brasileira de Metrologia, 1999. p.106-110.

TAGLIAFERRO, F.S.; FERNANDES, E.A.N.; BODE, P. Sample size optimization for multielemental analysis of Brazilian green coffee using INAA. Proceedings. METROLOGIA 2000, p.655-662, 2000.

TAGLIAFERRO, F.S. Metrologia em química: estudo da qualidade de cafés brasileiros. Piracicaba, 2002. 134p. Dissertação (Doutorado) - Centro de Energia Nuclear na Agricultura - Universidade de São Paulo.

TEIXEIRA, A. A. Qualidade de Café. Informativo Garcafé, Garça, jun. 1998.

THEODORO, V.C.A.; CAIXETA, I.F. Bases para a produção de café orgânico. Boletim Técnico Série Extensão. Lavras: Pró Reitoria de Extensão da UFLA. 1997. 69p.

THEODORO, V.C.A.; CARVALHO, J.G.; CORRÊA, J.B.; GUIMARÃES, R.J. Levantamento da fertilidade do solo e do estado nutricional de cafeeiros orgânicos no estado de Minas Gerais. In: CONGRESSO BRASILEIRO DE PESQUISAS CAFEEIRAS, 28., Caxambu, 2002. Resumos. Caxambu, 2002.

THEODORO, V.C.A. Caracterização de sistemas de produção de café orgânico, em conversão e convencional. Lavras, 2001. 214p. Dissertação (Mestrado) - Universidade Federal de Lavras. 
TORNQUIST, C.G.; HONS, F.M.; FEAGLEY, S.E.; HAGGAR, J. Agroforestry system effectes on soil characteristics of the Sarapiquí region of Costa Rica. Agriculture, Ecosystems and Enviroment, v.73, p.19-28, 1999.

WALDON, H.; GLIESSMAN, S.; BUCHANAN, M. Agrosystem response to organic and conventional managment practices. Agricultural Systems, v.57, n.01, p.65-75, 1998.

WANDER, M.M.; DRINKWATER, L.E. Fostering soil stewardship through soil quality assessment. Applied Soil Ecology, v.15, p.61-73, 2000.

YAMAGUCHI, T. \& FRIEND, D.T.C. Effect of leaf age and irradiance on photosyntesis of Coffea arabica. Photosyntesis. Prague, v. 13, p. 271-278, 1979.

ZAMBOLIM, L.; VENTURA, J.A. Resistência a doenças induzidas pela nutrição mineral das plantas. Revisão Anual de Patologia de Plantas, Passo Fundo, v.1, p.275-318, 1993. 